Hugo Rezende Henriques

\title{
Análise das respostas adaptativas quando um antígeno do vírus da dengue é direcionado para duas populações distintas de células dendríticas.
}

Dissertação apresentada ao Programa de Pós Graduação em Biologia da Relação PatógenoHospedeiro do Instituto de Ciências Biomédicas da Universidade de São Paulo, para obtenção do Título de Mestre em Ciências. 
Hugo Rezende Henriques

\section{Análise das respostas adaptativas quando um antígeno do vírus da dengue é direcionado para duas populações distintas de células dendríticas.}

Dissertação apresentada ao Programa de Pós Graduação em Biologia da Relação Patógeno Hospedeiro do Instituto de Ciências Biomédicas da Universidade de São Paulo, para obtenção do Título de Mestre em Ciências.

Área de Concentração: Parasitologia

Orientadora: Prof ${ }^{\mathrm{a}} \mathrm{Dr}^{\mathrm{a}}$ Silvia Beatriz Boscardin

Versão Original 
DADOS DE CATALOGAÇÃO NA PUBLICAÇÃO (CIP)

Serviço de Biblioteca e Informação Biomédica do

Instituto de Ciências Biomédicas da Universidade de São Paulo

reprodução não autorizada pelo autor

Rezende-Henriques, Hugo.

Análise das respostas adaptativas quando um antígeno do vírus da dengue é direcionado para duas populações distintas de células dendriticas. / Hugo Rezende Henriques. -- São Paulo, 2012.

Orientador: Silvia Beatriz Boscardin.

Dissertação (Mestrado) - Universidade de São Paulo. Instituto de Ciências Biomédicas. Departamento de Parasitologia. Área de concentração: Biologia da Relação Patógeno-Hospedeiro. Linha de pesquisa: Direcionamento de Antígeno para células dendríticas

Versão do título para o inglês: Analysis of the immune responses when a dengue virus antigen is targeted to two distinct populations of dendritic cells.

Descritores: 1. Células Dendríticas 2. Dengue 3. Vacina 4. Sistema Imune Adaptativo 5.DEC205 6. Camundongos I. Boscardin, Silvia Beatriz II. Universidade de São Paulo. Instituto de Ciências Biomédicas. Programa de Pós-Biologia da Relação Patógeno-Hospedeiro III. Título. 
Candidato(a):

Título da Dissertação:
Hugo Rezende Henriques.

Análise das respostas adaptativas quando um antígeno do vírus da dengue é direcionado para duas populações distintas de células dendríticas.

Orientador(a): $\quad$ Silvia Beatriz Boscardin.

A Comissão Julgadora dos trabalhos de Defesa da Dissertação de Mestrado, em sessão pública realizada a

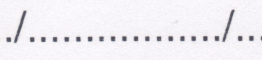
( ) Aprovado(a)
( ) Reprovado(a)

Examinador(a): Assinatura:

Nome:

Instituição:

Examinador(a): Assinatura:

Nome:

Instituição:

Presidente: Assinatura:

Nome:

Instituição: 
Este trabalho foi realizado no Laboratório de Direcionamento de Antígenos para Células Dendríticas, no Departamento de Parasitologia do Instituto de Ciências Biomédicas da Universidade de São Paulo, com o auxílio financeiro da Fundação de Amparo à Pesquisa do Estado de São Paulo (FAPESP, projeto ${ }^{\circ}$ 2010/03079-9), do Instituto Nacional de Ciência e Tecnologia de Vacinas (INCTV- CNPq) e do Banco BNP- Paribas. 


\begin{tabular}{|l|l|}
\hline UNIVERSIDADE DE SÃO PAULO \\
INSTITUTO DE CIÊNCIAS BIOMÉDICAS \\
Cidade Universitária “Armando de Salles Oliveira” \\
Av. Prof. Lineu Prestes, 2415 - Cep. 05508-900 São Paulo, SP - Brasil \\
Telefone :(55) (011) 3091.7733 - telefax : (55) (011)3091-8405 \\
e-mail: cep@icb.usp.br \\
COMISSÃO DEÉTICA NO USO DE ANIMAIS
\end{tabular}

Decl. CEEA.002/2010

DECLARAÇ $\tilde{A} O$

Em adendo ao Certificado 082/08/CEEA, datado de 26.08 .08 e por solicitação da Profa. Dra. Silvia Beatriz Boscardin, responsável pela linha de Pesquisa, autorizo a inclusão dos alunos: Eline Vital Rampazo, Ícaro Matioli Barbosa, Hugo Rezende Henriques ao Projeto de Pesquisa "Direcionamento de antígenos recombinantes para células dentríticas in vivo: uma nova estratégia para o desenvolvimento de vacinas", uma vez que se trata de utilização da mesma espécie animal e de métodos experimentais similares ao referido certificado.

São Paulo, 13 de janeiro de 2010.

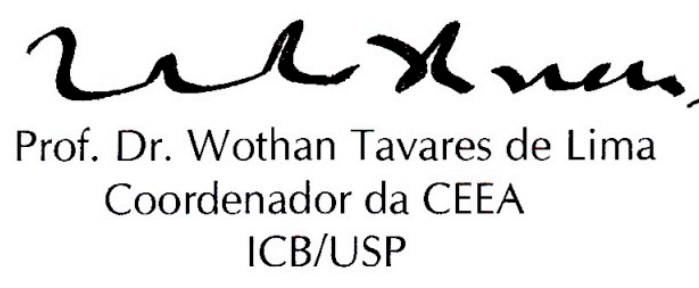




\section{AGRADECIMENTOS}

Agradeço em primeiro lugar à minha orientadora, Prof. Silvia Beatriz Boscardin, que sempre foi um apoio imprescindível em toda a caminhada ao longo deste projeto, ensinando, acompanhando, e principalmente tolerando os diversos contratempos que encontramos.

Agradeço também à equipe incrível que se reuniu no Laboratório de Direcionamento de Antígenos para Células Dendríticas: os mestrandos Kelly, Ícaro e Renan; a doutoranda Raquel; as pós-doutorandas Hildener e Catarina; e em especial ao apoio inestimável de nossa equipe técnica, Márcio e Samara; e é claro, à eterna companheira de experimentos, Eline.

A todos os inúmeros companheiros, colegas e colaboradores de nosso laboratório, em especial às tão presentes Profs. Beatriz Stolf Carboni e Daniela Santoro Rosa, ao Prof. Cláudio Romero Farias Marinho e aos membros de seus laboratórios. Em especial àqueles alunos que trabalham tão próximos a nós: Juliana e Suelen.

A todos os inúmeros colaboradores da Faculdade de Medicina da USP, InCor, Faculdade Paulista de Medicina, Faculdade de Farmácia e do Departamento de Imunologia do ICB-USP. Aos membros do LIM-60, em especial ao colega de longa data Rafael Ribeiro.

Aos Profs. Mauro Martins Teixeira (ICB-UFMG) e Ada Alves (FIOCRUZ-RJ) que cederam seus laboratórios e alunos para nos auxiliar em importantes experimentos.

À minha família que sempre me apoiou e incentivou na perseguição de meus sonhos. Aos meus amigos, que a pesquisa espalhou pelo Brasil e pelo mundo, e que tantas saudades causam, mas ao mesmo tempo tantas alegrias trazem com a presença, de diversas formas. Em especial, à Paula, Mariana, Clê, Davi, Jú, Dani, Pati, aos amigos incríveis da Biologia, e de forma ainda mais especial ao meu companheiro de todas as horas, Flay.

À USP e todos os seus funcionários, que sempre auxiliaram e deram todo o suporte necessário para que pudéssemos realizar nosso trabalho da forma mais eficiente e livre de percalços possível.

A todas as agências de fomento que acreditaram e apoiaram nosso projeto, dando-nos condições financeira de realizar esta pesquisa. 


\section{RESUMO}

Rezende HH. Análise das respostas adaptativas quando um antígeno do vírus da dengue é direcionado para duas populações distintas de células dendríticas. Dissertação (Mestrado em Biologia da interação Patógeno-Hospedeiro) - Instituto de Ciências Biomédicas, Universidade de São Paulo, São Paulo, 2012.

As células dendríticas (DCs) possuem importância crítica na interação entre o sistema imune inato e adaptativo, fagocitando antígenos e apresentando-os para linfócitos $\mathrm{T}$ no contexto de moléculas de MHC I e MHCII. As DCs são capazes de induzir tanto tolerância quanto fortes respostas adaptativas contra antígenos. Estas propriedades fazem com que as DCs sejam alvo de interesse para o desenvolvimento de novas estratégias vacinais. Na última década, uma estratégia que visa o direcionamento de antígenos diretamente para as diferentes populações DCs in vivo vem sendo desenvolvida e consiste na administração de anticorpos contra um receptor presente na superfície da DC em fusão com o antígeno de interesse. A administração de baixas doses destes anticorpos quiméricos, na presença de estímulos de maturação para as DCs, é capaz de ativar células T antígeno-específicas e induzir a produção de altos títulos de anticorpos. Neste estudo, comparamos o direcionamento da proteína NS1 de DENV2 para as duas principais populações de DCs presentes no baço, na presença de diferentes agonistas. Observamos que o agonista Poly I:C é capaz de induzir as respostas de Linfócitos T CD8 ${ }^{+}$ mais robustas, mas somente quando o antígeno foi direcionado para a população de DCs $\mathrm{CD}^{+} \mathrm{DEC}^{205^{+}}$. Em contraste, na presença do agonista $\mathrm{CpG}$ observamos uma resposta de células $\mathrm{T} \mathrm{CD}^{+}$considerável quando a proteína NS1 foi direcionada tanto para a população de DCs $\mathrm{CD} 8^{+} \mathrm{DEC}_{205^{+}}$quanto para a população CD8 ${ }^{-} \mathrm{DCIR} 2^{+}$. Consistente com este dado, na presença de Poly I:C, o direcionamento só gera proteção contra a infecção experimental por DENV2 quando a proteína NS1 é direcionada para a população de DCs DEC205 ${ }^{+}$, sendo esta proteção dependente de Linfócitos $\mathrm{T}_{\mathrm{CD}} 8^{+}$e $\mathrm{CD}^{+}$, e aparentemente independente de anticorpos específicos anti-NS1.

Palavras-chave: Células Dendríticas. Dengue. Vacina. Sistema Imune Adaptativo. DEC205. Camundongos. 


\begin{abstract}
Rezende HH. Analysis of the adaptive immune responses when a dengue virus antigen is targeted to two distinct populations of dendritic cells. Masters Thesis (Biology of the Pathogen-Host interaction) - Instituto de Ciências Biomédicas, Universidade de São Paulo, São Paulo, 2012.

Dendritic Cells (DCs) are critical in the interaction between the innate and the adaptive immune system, phagocyting and presenting antigens to $\mathrm{T}$ lymphocytes in the context of MHCI and MHCII molecules. DCs are able to induce both tolerance and strong adaptive immune responses against antigens. These properties make the dendritic cells the perfect target for the development of new vaccine strategies. During the last decade, a strategy aimed at targeting antigens to different DCs populations in vivo has been developed, and consists on the administration of antibodies specific to a DC cell surface endocytic receptor fused to an antigen of interest. The administration of low doses of these quimeric antibodies, in the presence of DC maturation stimuli, is able to activate antigen-specific T cells and to induce high titers of antigen-specific antibodies. In this study, we evaluated the differences in $\mathrm{T}$ and B cell responses when the NS1 protein from the DENV2 was directed to the two main populations of DCs present on mice spleen along with different agonistic molecules. We observed the highest $\mathrm{CD} 8^{+} \mathrm{T}$ cell responses when the agonist Poly I:C was used, but only when targeting was directed to the $\mathrm{CD} 8^{+} \mathrm{DEC} 205^{+} \mathrm{DCs}$ population. In contrast, in the presence of agonist $\mathrm{CpG}$ we observed considerable $\mathrm{CD}^{+} \mathrm{T}$ cell responses when the NS1 protein was targeted to either the $\mathrm{CD} 8^{+} \mathrm{DEC} 205^{+}$or the $\mathrm{CD} 8^{-} \mathrm{DCIR} 2^{+} \mathrm{DC}$ population. Consistent with the data, in the presence of Poly I:C, only the targeting of the NS1 antigen to the DEC205 ${ }^{+}$DCs was able to protect mice against a lethal experimental challenge with DENV2. This protection was dependent on both $\mathrm{CD} 8^{+}$and $\mathrm{CD}^{+} \mathrm{T}$ cell responses and, apparently, independent of anti-NS1 specific antibodies.
\end{abstract}

Keywords: Dendritic Cells. Dengue. Vaccine. Adaptive Immune System. DEC205. Mice. 


\section{LISTA DE FIGURAS}

FIGURA 01 - Alinhamento múltiplo, pelo método clustal W, das sequências de aminoácidos das cadeias pesadas dos anticorpos $\alpha \mathrm{DEC}, 33 \mathrm{D} 1$ e Iso. .53

FIGURA 02 - Amplificação e clonagem do gene $n s 1$ do vírus DENV2. 54

FIGURA 03 - Normalização das concentrações de anticorpos quiméricos $\alpha$ DEC-NS1, 33D1NS1 e Iso-NS1.....

FIGURA 04 - Ligação dos anticorpos quiméricos a populações de células dendríticas presentes no baço de camundongos BALB/c. .56

FIGURA 05 - A proteína NS1 recombinante produzida por nosso grupo possui tamanho e pureza comparáveis à proteína controle.

FIGURA 06 - Direcionamento da NS1 para as DCs DEC205 ${ }^{+}$em presença de Poly I:C induz um maior número de células $\mathrm{T} \mathrm{CD}^{+}$produtoras de $\mathrm{IFN}-\gamma$ do que o direcionamento para as DCs DCIR2 $2^{+}$

FIGURA 07 - Direcionamento da NS1 para as DCs DEC $205^{+}$ou DCIR2 ${ }^{+}$em presença de $\mathrm{CpG}$ induz números semelhantes de células $\mathrm{T} \mathrm{CD} 8^{+}$produtoras de IFN- $\gamma$. 59

FIGURA 08 - Em presença de MDP, o direcionamento da NS1 para as DCs DCIR2 ${ }^{+}$induz maior número de células $\mathrm{T} \mathrm{CD}^{+}$produtoras de IFN- $\gamma$ quando comparado ao direcionamento para as DCs DEC205 ${ }^{+}$......

FIGURA 09 - Imunização com anticorpos quiméricos associados à proteína NS1 induz resposta humoral, principalmente nos animais imunizados com Poly I:C e CpG.

FIGURA 10 - Imunização com 2 doses de $5 \mu \mathrm{g}$ dos anticorpos quiméricos associados à proteína NS1 na presença de poly I:C induz forte resposta humoral.

FIGURA 11 - Imunização com o anticorpo quimérico $\alpha$ DEC-NS1 na presença de Poly I:C é capaz de proteger parcialmente os animais do desafio com o vírus DENV2.

FIGURA 12 - Animais imunizados com o anticorpo quimérico $\alpha$ DEC-NS1 apresentam menor morbidade após o desafio quando comparados ao animais imunizados com os demais anticorpos.

FIGURA 13 - A depleção das populações de células $\mathrm{T} \mathrm{CD}^{+}$e $\mathrm{TCD}^{+}$reduz a proteção conferida pela imunização com o anticorpo quimérico $\alpha$ DEC-NS1 na presença de Poly $\mathrm{I}: \mathrm{C}$.

FIGURA 14 - Grau de morbidade dos animais desafiados com DENV2 após imunização com anticorpos quiméricos na presença de Poly I:C. 
FIGURA 15 - Imunização com anticorpos quiméricos associados a proteína MSP $1_{19}$-PADRE induz resposta humoral, independente do agonista utilizado.

FIGURA 16 - Produção de IFN- $\gamma$ contra peptídeo PADRE induzida pela imunização com anticorpos quiméricos na presença de diferentes agonistas. 66

FIGURA 17 - Proliferação de Linfócitos $\mathrm{T} \mathrm{CD}^{+}$re-estimulados in vitro com peptídeo PADRE induzida pela imunização com anticorpos quiméricos na presença de diferentes agonistas

FIGURA 18 - Porcentagem de Linfócitos $\mathrm{T} \mathrm{CD}^{+}$expressando IFN- $\gamma$ após re-estimulação in vitro com peptídeo PADRE induzida pela imunização com anticorpos quiméricos na presença de diferentes agonistas. 68

FIGURA 19 - Porcentagem de Linfócitos T CD4 ${ }^{+}$expressando IL-2 após re-estimulação in vitro com peptídeo PADRE induzida pela imunização com anticorpos quiméricos na presença de diferentes agonistas. 68

FIGURA 20 - Porcentagem de Linfócitos T $\mathrm{CD}^{+}{ }^{+}$expressando TNF- $\alpha$ após re-estimulação in vitro com peptídeo PADRE induzida pela imunização com anticorpos quiméricos na presença de diferentes agonistas. 69 


\section{SUMÁRIO}

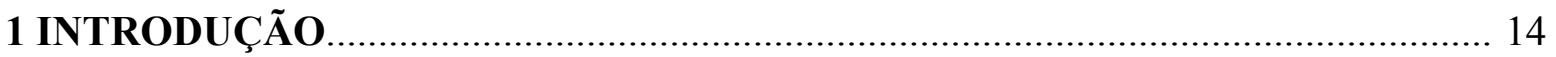

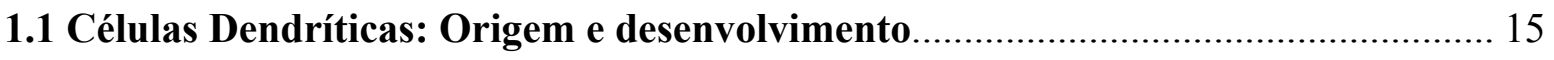

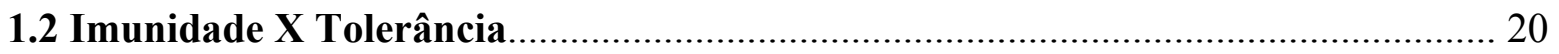

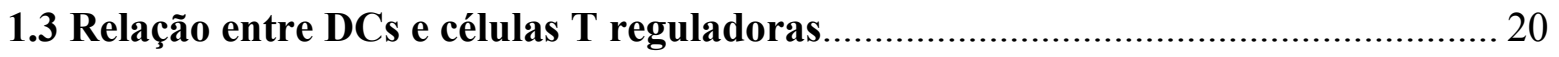

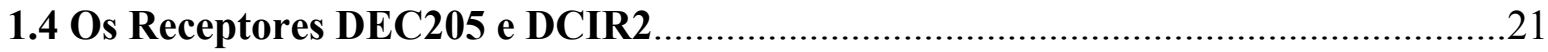

1.5 As populações de células dendríticas do baço: semelhanças e diferenças................ 22

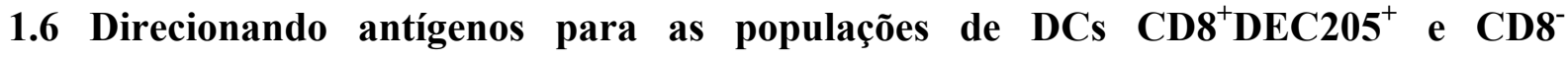

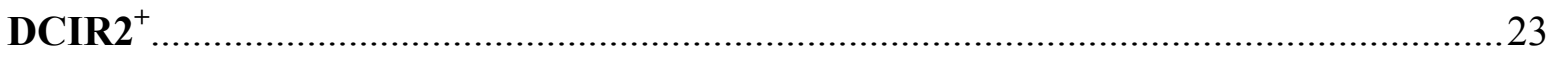

1.7 Receptores de Padrões de Patógenos e seu papel nos inflamossomos......................28

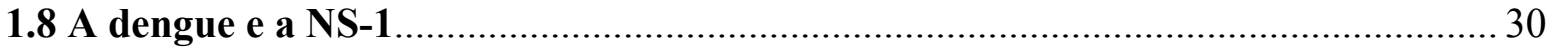

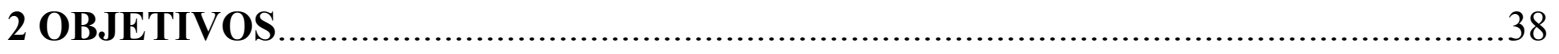

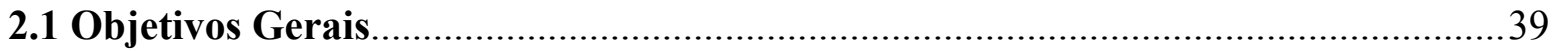

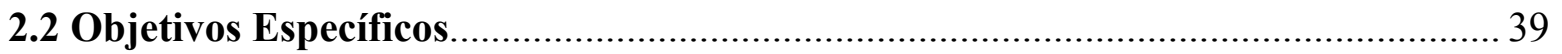

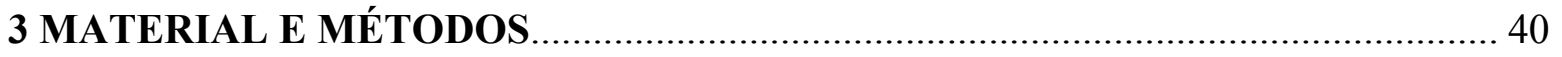

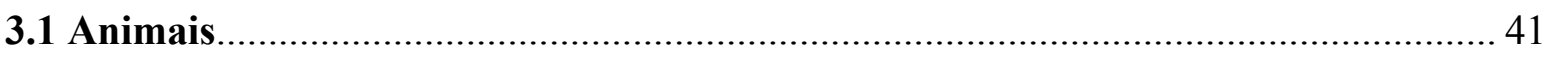

3.2 Obtenção dos plasmídeos codificando para as cadeias leve e pesada dos anticorpos

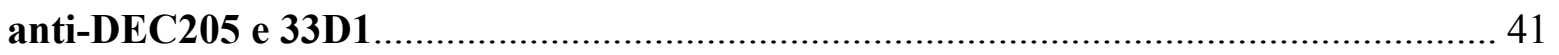

3.3 Amplificação das sequências de DNA da proteína NS1 por PCR ............................. 41

3.4 Clonagem do gene ns1 de DENV2 em fusão com os plasmídeos codificando as cadeias

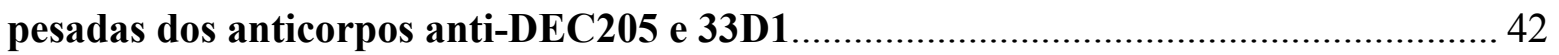

3.5 Produção dos anticorpos quiméricos por transfecção transiente de células HEK293T e purificação dos mesmos à partir dos sobrenadantes das culturas.

3.6 Avaliação da integridade dos anticorpos quiméricos e da proteína NS1 fusionada a eles

3.7 Ensaio para detecção de LPS. 45

3.8 Ensaio de ligação dos anticorpos híbridos a DCs presentes no baço de camundongos

3.9 Clonagem, expressão e purificação da proteína recombinante NS1 produzida em bactérias. 
3.10 Imunização de camundongos com os diferentes anticorpos quiméricos na presença de diferentes estímulos de ativação para as DCs e análise da resposta imune celular gerada pelas diferentes combinações

3.11 Ensaio ELISPOT para análise do número de células produtoras de IFN- $\gamma$. 47

3.12 Análise da sobrevivência dos animais imunizados após desafio utilizando o vírus NGC DENV2. 48

3.13 Ensaio de ELISA

3.14 Ensaio de marcação intracelular para detecção das citocinas inflamatórias IFN- $\gamma$, IL-2 e TNF- $\alpha$ 50

3.15 Ensaio de proliferação por diluição do corante CFSE 50

3.16 Análise dos resultados 51

4 RESULTADOS. 52

4.1 Amplificação e clonagem do gene ns1 de DENV2 em fusão com os genes codificando para as cadeias pesadas dos anticorpos $\alpha$ DEC205 e 33D1. 53

4.2 Transfecção de células HEK293T e purificação dos anticorpos quiméricos associados a NS1. 54

4.3 Ensaio de ligação dos anticorpos quiméricos contendo a proteína NS1 em DCs provenientes do baço de camundongos. .55

4.4 Produção da proteína NS1 recombinante. 56

4.5 Avaliação da resposta de células $\mathrm{T}^{\mathrm{C}} \mathrm{CD}^{+}$após a imunização com os anticorpos quiméricos na presença de diferentes estímulos de maturação para DCs. .58 4.6 Avaliação da resposta humoral anti-NS1 após a administração de uma dose dos anticorpos quiméricos na presença de diferentes estímulos de maturação para DCs...60 4.7 Avaliação da proteção conferida pela imunização de camundongos com os anticorpos quiméricos.

4.8Avaliação das respostas de células $\mathrm{T} \mathrm{CD4}^{+}$ao peptídeo PADRE em camundongos imunizados com os anticorpos quiméricos contendo a proteína MSP1 19-PADRE...... 65

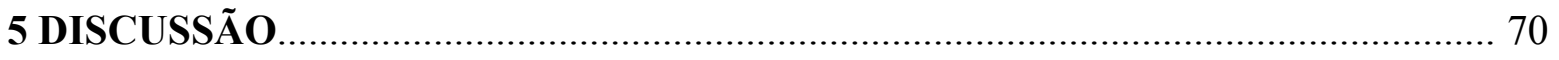

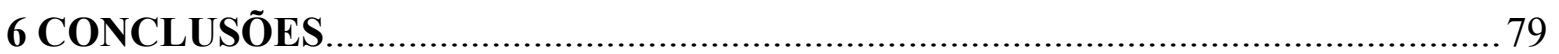

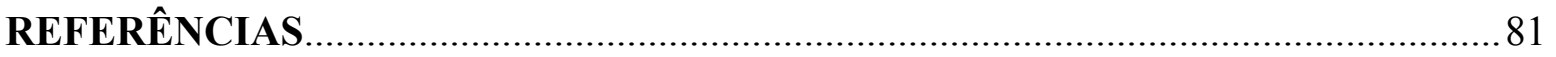


1. INTRODUÇÃO 


\subsection{Células Dendríticas: Origem e desenvolvimento}

As Células Dendríticas (DCs) são células fagocíticas profissionais e apresentadoras de antígenos (APCs) que foram inicialmente descritas em preparações de células mononucleares de baço de murino (Mosier, 1967). Inicialmente elas foram diferenciadas de macrófagos e monócitos por sua morfologia distinta (Steinman e Cohn, 1973; Steinman et al., 1974; Steinman e Cohn, 1974), mas outras importantes funções foram logo também descritas, como sua alta eficiência na estimulação da proliferação de Linfócitos $\mathrm{T}$ em ensaios de Mixed Leucocyte Reaction (Steinman e Witmer, 1978) e sua eficiência em capturar e processar antígenos, promovendo resposta de células T efetoras (Nussenzweig et al., 1980).

Recentemente, uma série de marcadores moleculares foram descritos na superfície celular das DCs, facilitando sua identificação (Shortman e Liu, 2002; Bursch et al., 2007; Dudziak et al., 2007). Contudo, diferente de outros tipos celulares como Linfócitos T e B, ainda não se conhece um marcador exclusivamente expresso por DCs. Para tanto contribui o fato de que existe uma variedade de subpopulações de DCs descritas, nos mais diversos compartimentos corporais tanto de humanos quanto de camundongos.

Os primeiros estudos in vitro demonstraram que monócitos humanos e murinos expostos a granulocyte-macrophage colony-stimulating factor (GM-CSF) dão origem a uma mistura de granulócitos, macrófagos e a um tipo de célula dendrítica, que expressa altos níveis de CD11c e MHCII e é eficiente na apresentação de antígeno (Sallusto e Lanzavecchia, 1994; Bender et al., 1996). Entretanto, as células dendríticas não parecem se originar de monócitos no organismo em steady state. DCs murinas podem também ser produzidas in vitro pela exposição de células da medula óssea a fms-like tyrosine kinase 3 ligand (F1t3L), sendo este um fator de crescimento necessário às DCs in vivo (Naik et al., 2005). As células dendríticas obtidas através deste procedimento se assemelham mais às observadas in vivo, inclusive podendo ser observadas as diferentes populações mais comuns de DCs: Células dendríticas clássicas $\mathrm{CD}^{+}$, Células dendríticas clássicas $\mathrm{CD}^{-}$e Células dendríticas plasmocitóides (pDCs).

Embora estas sejam as populações mais comuns de dendríticas descritas, a sua distribuição varia entre os diversos órgãos linfóides do corpo, com distintas subpopulações descritas em cada um deles. O baço de camundongos, onde as DCs foram primeiramente descritas, contém duas populações principais de dendríticas convencionais, que diferem na expressão de diversos genes, além de possuírem capacidades distintas quanto à apresentação de antígenos (Shortman et al., 2002 e Dudziak et al., 2007). Uma população, 
convencionalmente identificada por expressar a cadeia $\alpha$ do coreceptor CD8 e o receptor CD205 (ou DEC205, por ser um receptor constituído de 10 cadeias de lectina, portanto uma dectina), se localiza principalmente nas áreas de células $\mathrm{T}$ e na zona marginal, enquanto que uma outra população, que não expressa a molécula CD8 $\alpha$ e expressa o receptor DCIR2 ("Dendritic Cell Immuno Receptor 2"), é encontrada nos canais comunicantes (do inglês "bridging channels") e na polpa vermelha (Idoyaga et al., 2009). No entanto, após ativação, ambas populações movem-se para as áreas de células T (Idoyaga et al., 2009 e De Smedt et $a l .$, 1996). As evidências mais recentes da literatura apontam para uma maior capacidade da população $\mathrm{CD}^{+} \mathrm{CD} 205^{+}$em capturar e realizar a cross-presentation de antígenos de células apoptóticas (Iyoda et al., 2002; Belz et al., 2002 e den Haan et al., 2000). As células CD8$\mathrm{DCIR}^{+}$por sua vez parecem ser mais eficientes no processamento de antígenos para apresentação via MHCII (Dudziak et al., 2007).

Os linfonodos também contém duas populações principais de DCs residentes, as $\mathrm{CD}^{+} \mathrm{CD} 205^{+} \mathrm{e}$ as $\mathrm{CD}^{-} \mathrm{CD} 11 \mathrm{~b}^{+}$que parecem corresponder àquelas encontradas no baço, respectivamente $\mathrm{CD}^{+} \mathrm{CD} 205^{+}$e $\mathrm{CD} 8^{-} \mathrm{DCIR} 2^{+}$, inclusive no tocante às suas funções (Shortman et al., 2002; Belz et al., 2002 e Allan et al., 2006). Os linfonodos possuem ainda outras populações de DCs, estas migratórias, que transitam dos tecidos através da linfa e se instalam temporariamente nos linfonodos de forma dependente de CCR7 (Ohl et al., 2004). Evidências apontam que estas células migratórias são capazes de transferir antígenos para as DCs residentes $\mathrm{CD}^{+}$, propiciando o fenômeno de cross-presentation destes antígenos, via MHCI (Allan et al., 2006).

As DCs são encontradas ainda nos mais diversos tecidos corporais e, após capturar antígenos da periferia, migram para os linfonodos drenantes pela via aferente, onde iniciam as diversas respostas imunes (Liu e Nussenzweig, 2010).

As pDCs são encontradas nos mais diversos tecidos linfóides e não linfóides, e comparadas às DCs clássicas, as DCs plasmocitóides expressam níveis mais baixos de MHCII e são bem menos eficientes em induzir a proliferação de linfócitos T (Nakano et al., 2001; Asselin-Paturel et al., 2001). No entanto, em contextos inflamatórios, as pDCs podem ser ativadas e se diferenciar em um subtipo específico de $\mathrm{pDC} \mathrm{CD}^{+}$no baço, que possui maior capacidade em primar linfócitos T (O’Keffe et al., 2002; Schlecht et al., 2004; Villadangos e Young, 2008).

Outros esforços recentes visam caracterizar as DCs não apenas por sua distribuição e fenótipo, mas por sua origem. As DCs, como os demais leucócitos, se originam das células hematopoiéticas da medula óssea, mas as linhagens celulares que originam os diferentes tipos 
de DCs ainda são pouco estudadas. Embora alguns estudos de transferência adotiva indiquem que tanto precursores linfóides quanto os mielóides sejam capazes de dar origem a alguns tipos de DCs, os estudos mais recentes indicam que no organismo sadio, elas se originam principalmente de um precursor mielóide (Manz et al., 2001 e Traver et al., 2000).

Os primeiros experimentos pareciam indicar que as DCs podiam se originar de monócitos, pois estes, ao realizar o fenômeno de transmigração reversa, para penetrar nos vasos linfáticos a partir dos tecidos, perdem a expressão dos marcadores clássicos de monócitos - CD14 e CD67 - e passam a expressar níveis consideráveis de HLA-DR e CD54, e quando realizam a fagocitose de partículas, expressam níveis ainda maiores de CD80, CD86, HLA-DR, DC-LAMP e CD83, todos estes também expressos em DCs (Randolph et al., 1998). No entanto, nenhum desses marcadores é exclusivo de DCs, tampouco são utilizados para definir a linhagem das células dendríticas (Sprent, 1995).

Outros experimentos observaram que monócitos $\left(\mathrm{CD} 11 \mathrm{~b}^{+} \mathrm{F} 4 / 80^{+}\right)$na pele são capazes de fagocitar partículas e adentrarem nos linfonodos drenantes, além de aumentarem a expressão de MHCI, MHCII e CD86. No entanto, estas células não expressavam os marcadores clássicos de DCs como CD11c e a cadeia alfa do CD8. Portanto, os monócitos da pele não se diferenciaram em DCs clássicas após sua migração para linfonodos, muito embora estas células apresentem várias características de DCs, sendo chamados por alguns autores de $T N F-i N O S$-producing-DCs (Tip-DCs), por sua capacidade de expressar altos níveis de TNF- $\alpha$ e iNOS (Randolph et al., 1999 e Serbina et al., 2003). Conjuntamente, estes experimentos permitem-nos concluir que monócitos ativados não se diferenciam em DCs clássicas, embora compartilhem algumas características destas. Outra série de experimentos tentaram avaliar a capacidade de monócitos se diferenciarem em DCs. Contudo, embora os progenitores derivados da medula óssea tenham tal capacidade, monócitos isolados não mantêm esta capacidade, sendo que a fração restante (livre de monócitos) possui a capacidade de repovoar os tecidos com células dendríticas (Fogg et al., 2006 e Naik et al., 2006). Mais recentemente, um experimento envolvendo uma linhagem de camundongos em que somente os monócitos expressavam EGFP demonstrou que as DCs clássicas não expressavam EGFP, portanto não eram derivadas de monócitos (Jakubizick et al., 2008).

Descartados os monócitos como células progenitoras das DCs clássicas, manteve-se a problemática sobre a origem destas células. Para identificar as células progenitoras das células dendríticas clássicas partiu-se da observação de que estas células expressariam Flt3 (D’Amico e Wu, 2003). Partindo-se do precursor mielóide comum (CMP), identificou-se um precursor comum para monócitos, macrófagos e DCs clássicas, que é incapaz de se diferenciar em 
células polimorfonucleares, células NK e em linfócitos. Portanto estas células, chamadas de Precursor de Macrófagos e Células Dendríticas (MDP), são mais restritas do que as CMPs, das quais elas derivam (Fogg et al., 2006 e Liu et al., 2009). Em seguida foi identificado um Precursor Comum das Células Dendríticas (CDP). Este tipo celular foi caracterizado (CD3$\mathrm{CD}^{-} \mathrm{NKT}^{-}$Ter119C $\mathrm{D} 115^{+} \mathrm{Flt3}^{+} \mathrm{CD} 117^{\text {low }}$ ) e descrito como derivado das MDPs porque a transferência adotiva desse tipo celular dá origem apenas a DCs, enquanto a transferência de MDPs dá origem a monócitos e às próprias CDPs. Ainda de interesse é o fato de estes experimentos terem demonstrado a divergência entre a linhagem monocítica e dendrítica ainda na medula óssea, visto que nenhum destes tipos celulares é observado na circulação (Liu et al., 2009).

Uma vez identificados os principais tipos celulares precursores das células dendríticas na medula óssea, e tendo em vista que não se encontram CDPs na circulação de murinos, restava ainda a dúvida sobre qual tipo celular era responsável por deixar a medula óssea e povoar os diversos tecidos nos quais encontramos as DCs. A identificação deste tipo celular, denominado pré-DC foi possível graças à expressão persistente de Flt3 durante todo o desenvolvimento das células dendríticas (Liu et al., 2009). A complexa identificação deste precursor deve-se, muito provavelmente, por sua meia-vida extremamente curta na circulação sanguínea (Liu et al., 2007).

As pré-DCs são capazes de povoar os mais diversos tecidos e, no caso do baço, se diferenciar nos dois subtipos mais comuns de células dendríticas presentes neste órgão: $\mathrm{CD}^{+} \mathrm{CD}^{2} 25^{+}$e CD8$^{-} \mathrm{DCIR}^{+}$; assim como no caso dos linfonodos (Liu et al., 2009). Também se diferenciam nas populações de dendríticas mais comuns encontradas em órgãos não

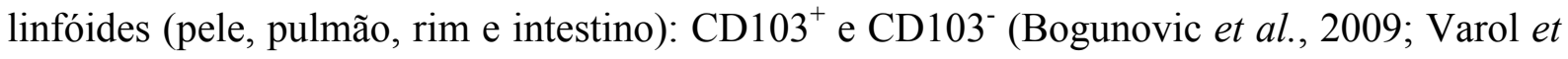
al., 2009 Ginhoux et al., 2009). Isso demonstra a grande plasticidade destas células, e sua capacidade de dar origem a uma diversidade de tipos de DCs tanto em tecidos linfóides quanto não-linfóides. Entretanto, não se pode afirmar que elas dariam origem a todos os tipos de DCs conhecidas, uma vez que em experimentos de transferência adotiva deste tipo celular não se observou, por exemplo, o repovoamento do compartimento de células de Langerhans (Ginhoux et al., 2006).

Há, contudo, uma divergência sobre a origem das DCs plasmocitóides. Sabe-se que estas não têm origem nas pré-DCs, umas vez que a transferência destas células não repovoa o compartimento de pDCs. O estudo de Liu et al. (2009) demonstrou de uma forma inovadora que MDPs e CDCs (Precursor Comum de pDCs e cDCs) possuem a capacidade de se diferenciar em pDCs, e é justamente a perda desta capacidade que caracteriza a distinção 
funcional entre as CDCs e as pré-DCs. Além disso, outros estudos indicam que as pDCs podem se diferenciar completamente na medula óssea, a partir de um precursor CDP CD11c ${ }^{-}$, embora já tenha sido observado uma célula semelhante às CDPs, sendo esta CD11 $\mathrm{c}^{+}$, no baço, com capacidade de originar pDCs e pré-DCs (Onai et al., 2007). Tais estudos abrem a possibilidade de que CDPs possam, sob certas circunstâncias ainda indefinidas, adquirir a capacidade de deixar a medula óssea, através da circulação (Schmid et al., 2010).

Outro ponto controverso refere-se aos fatores essenciais à manutenção das populações de DCs no organismo saudável. GM-CSF, M-CSF e Flt3L são três conhecidos fatores de crescimento essenciais ao desenvolvimento das células da linhagem mielóide tanto in vivo quanto in vitro. O receptor Flt3 é expresso precocemente na hematopoiese, em progenitores de linfócitos e em todos os precursores mielóides (Karsunky et al., 2003). Entretanto, exceto pelas pré-DCs, a expressão deste receptor é perdida pela grande maioria dos leucócitos quando estes atingem a circulação (Liu et al., 2009). No entanto, mesmo em progenitores que perderam a expressão do receptor Flt3, a indução de sua expressão ou a ativação da cascata de sinalização deste receptor foi capaz de restaurar o potencial destas células em dar origem a cDCs e pDCs (Onai et al., 2006). Isto se dá provavelmente devido a um loop de sinalização positiva presente na cascata de sinalização de Flt3, onde a ativação deste receptor e sua via intracelular, dependente de stat3, induzem a um aumento da expressão do próprio receptor (Metcalf, 1998).

Ao contrário, a expressão do receptor de M-CSF é mantida pelas células da linhagem monocítica mas perdida pelas pré-DCs e pelas DCs (Liu et al., 2009). Interessantemente a deficiência de M-CSF, além de depletar o desenvolvimento de monócitos e macrófagos, também impede o desenvolvimento do compartimento de Células de Langerhans, mas não das células dendríticas do baço ou dos linfonodos (Witmer et al., 1993). A super expressão de Flt3L leva à expansão seletiva das populações de Células Dendríticas e à completa diferenciação de DCs nos órgãos linfóides (Marakovsky et al., 1996).

O compartimento de DCs é constantemente renovado nos diversos órgãos linfóides e não-linfóides. Apesar disso, experimentos demonstraram que as Células Dendríticas não se originavam unicamente dos precursores pré-DCs do sangue, mas que as DCs também eram capazes de se dividir, dando origem a novas células, que auxiliam na manutenção do compartimento de DCs nos tecidos (Kabashima et al., 2005). Dessa forma, acredita-se atualmente que a renovação das células dendríticas mortas nos diversos tecidos se dá tanto de novo via pré-DCs do sangue quanto in situ via divisão das próprias DCs (Liu et al., 2007). A divisão das DCs é controlada pelo receptor de linfotoxina- $\beta$ (LT- $\beta$ R) e Flt3L, embora a ação 
do LT- $\beta$ R parece se limitar à população de DCs CD8- (Kamath et al., 2002), diferente de Flt3L, que atua sobre todas as sub-populações (Maraskovsky et al., 1996).

Outros estudos parecem comprovar que GM-CSF não é essencial para a renovação do compartimento de DCs no organismo sadio; contudo esta citocina age de uma forma expressiva durante a inflamação, sendo importante para a maturação das DCs durante o processo inflamatório (Vremec et al., 1997). Além disso, embora os níveis séricos de GMCSF sejam baixos, parece haver uma ação local dessa citocina, em sinergia com Flt3L, na geração do compartimento dermal de DCs CD11b ${ }^{+}$(Kingston et al., 2009).

\subsection{Imunidade X Tolerância.}

Tipicamente, as DCs estimuladas apenas por padrões aos quais sejam sensibilizadas, sem um estímulo inflamatório concomitante, possuem uma ação imunoreguladora, podendo inclusive contribuir para indução e manutenção de tolerância aos mais diversos tipos de substâncias. Por outro lado, as DCs são ativadas quando entram em contato com estímulos aos quais não foram sensibilizadas, especialmente quando estes estímulos são concomitantes com uma modificação no perfil de citocinas. Neste estado as DCs se tornam potentes APCs, sendo ainda capazes de liberar citocinas e quimiocinas (Steinman et al., 2003).

\subsection{Relação entre DCs e células T reguladoras.}

As DCs estão envolvidas em processos de tolerância, tanto central quanto periférica, sendo que, mesmo no timo, as DCs residentes (DCs tímicas) já foram descritas como centrais no processo de seleção negativa (Brocker et al., 1997). Além delas, as DCs presentes na circulação podem entrar no timo e parecem também estar envolvidas no estabelecimento da tolerância central e na indução de Linfócitos $\mathrm{T}$ regulatórios específicos para determinados antígenos (Bonasio et al., 2006).

A relação entre as DCs e as células T reguladoras (Tregs) ainda é pouco estudada, mas alguns dados parecem relevantes. Estudos apontam que quando há uma diminuição no número de Tregs, há um concomitante aumento no número de DCs nos órgãos linfóides (Kim et al., 2007). Embora tenha-se inicialmente imaginado que este aumento ocorria devido a um aumento no aporte de precursores da medula óssea, observou-se que, na verdade, ocorre um aumento na divisão celular deste tipo celular na periferia, sendo este evento dependente de uma produção aumentada de Flt3L (Liu et al., 2009). 
Outros estudos, no entanto, demonstraram que um aumento no número de DCs através da injeção de Flt3L, leva a um aumento concomitante da população de Tregs. Por outro lado, uma diminuição da população de DCs, pela deleção genética de Flt3L, leva a uma diminuição também da população de Tregs. Por esta razão, postulou-se que haja uma fina regulação entre estes dois tipos celulares, mediado por Flt3, que auxilia na manutenção das populações fisiológicas destas células no organismo sadio (O’Keeffe et al., 2005). Alterações neste balanço podem acarretar diferentes modificações no curso de doenças auto-imunes (O'Keeffe et al., 2005). Este mecanismo é consistente com os papéis propostos para as DCs na manutenção da tolerância e na regulação das respostas imunes in vivo (Liu e Nussenzweig, 2010).

Os primeiros estudos envolvendo direcionamento de antígenos para células dendríticas surpreenderam ao observar que, quando um antígeno era direcionado para o receptor DEC205 de DCs, ocorria uma expansão dos clones de Linfócitos $\mathrm{T}$ específicos para antígenos daquela proteína mas, em seguida, havia uma retração e desaparecimento desta população, gerando tolerância aos antígenos em questão (Hawiger et al., 2001; Bonifaz et al., 2002). Estudos subsequentes demonstraram que o direcionamento do antígeno na ausência de um estímulo de maturação para as DCs era capaz de gerar tolerância a partir da indução de diferenciação de Linfócitos $\mathrm{T} \mathrm{CD}^{+}{ }^{+}$Foxp3 $3^{-}$em Linfócitos $\mathrm{T}$ reguladores $\mathrm{CD}^{+} \mathrm{Foxp}^{+}$, de uma forma dependente de TGF- $\beta 1$ (Luo et al., 2007). Este mesmo grupo, anos antes, havia demonstrado como o direcionamento de um antígeno de células beta para DCs era capaz de reverter quadros experimentais de diabetes em camundongos através da expansão de Linfócitos $\mathrm{T}$ $\mathrm{CD} 4{ }^{+} \mathrm{CD} 25^{+}$específicos, mais tarde descritos como Tregs (Tarbell et al., 2004).

Outro trabalho envolvendo o direcionamento de células mortas para DCs in vivo novamente demonstrou a indução de tolerância e ausência de respostas contra os antígenos das células direcionadas (Liu et al., 2002). Embora ainda seja um campo obscuro e controverso, a indução e a expansão de clones de células Tregs específicas para determinados antígenos tem sido estudada por diferentes grupos, com resultados igualmente promissores (Kretschmer et al., 2005; Mahnke et al., 2003; Yamazaki et al., 2008).

\subsection{Os Receptores DEC205 e DCIR2.}

Tanto o receptor DEC205 (CD205) quanto o DCIR2 são receptores endocíticos e, portanto, são endocitados pelas DCs quando sofrem ligação de seus respectivos ligantes (Tacken et al., 2007). Até o presente momento, os ligantes naturais destes receptores ainda 
não foram identificados, entretanto algumas diferenças já foram apontadas entre as populações de DCs que expressam um ou outro receptor (Dudziak et al., 2007, Steinman e Idoyaga, 2010).

$\mathrm{O}$ receptor DEC205 pertence à família das lectinas tipo $\mathrm{C}$ do tipo I que inclui o receptor conhecido como MMR (“macrophage mannose receptor”) (Jiang et al., 1995; Mahnke et al., 2000). Como o MMR, o receptor DEC205 apresenta um domínio aminoterminal intracelular rico em cisteínas, um domínio de fibronectina tipo II e múltiplos domínios de reconhecimento de carboidratos (revisto por Figdor et al., 2002). O DEC205 é altamente expresso pelas DCs presentes nas zonas de células $\mathrm{T}$ dos tecidos linfóides, particularmente nas DCs CD ${ }^{+}$(den Haan et al, 2000).

O receptor DCIR2 também é uma lectina tipo C, porém do tipo II. Ao contrário do receptor DEC205, ele contém apenas um domínio de ligação a carboidratos na porção carboxi-terminal extracelular (revisto por Figdor et al, 2002).

\subsection{As populações de células dendríticas do baço: semelhanças e diferenças.}

Vários artigos publicados principalmente na última década apontam para uma dicotomia funcional no papel exercido pelas DCs CD8 ${ }^{+}$DEC $205^{+}$versus as DCs CD8 ${ }^{-}$DCIR2 ${ }^{+}$ no que diz respeito à indução da resposta imune contra patógenos. Com base nos dados disponíveis, as DCs $\mathrm{CD} 8^{+} \mathrm{DEC} 205^{+}$parecem ser especializadas na captura de células mortas (Iyoda et al., 2002) e na ativação de células T CD8 ${ }^{+}$durante infecções virais, enquanto que as DCs CD8DCIR2 ${ }^{+}$parecem estar envolvidas preferencialmente na indução de respostas de células $\mathrm{T} \mathrm{CD}^{+}$, particularmente durante infecções bacterianas (revisto por Villadangos e Schnorrer, 2007). Este conceito ganhou suporte quando Dudziak et al. (2007) propuseram que a habilidade preferencial das DCs $\mathrm{CD}^{+} \mathrm{DEC}_{205^{+}} \mathrm{e} \mathrm{CD}^{-} \mathrm{DCIR} 2^{+}$em induzir células T $\mathrm{CD} 8^{+}$ e $\mathrm{CD} 4^{+}$correlaciona com a capacidade diferencial destas populações de processar e apresentar antígenos associados a moléculas de MHC I ou II, respectivamente. Porém, é importante ressaltar que as $\mathrm{DCs} \mathrm{CD} 8^{+} \mathrm{DEC} 205^{+}$não estão apenas envolvidas na ativação de células $\mathrm{T}$ $\mathrm{CD} 8^{+}$. Há estudos que indicam que elas podem também ativar células $\mathrm{T} \mathrm{CD}^{+}$durante infecções virais, bacterianas e parasitárias (Belz et al.,2005; Maroof e Kaye, 2008; Yarovinsky et al., 2006). De fato, esta população de DCs parece ter papel importante na indução de respostas protetoras do tipo Th1 contra patógenos intracelulares (Allan et al., 2006; Mount et al., 2008; Belz et al., 2005; Sponaas et al., 2006; Yarovinsky et al., 2006). Estas células são capazes de ativar linfócitos Th1 por mecanismos dependentes (Maldonado- 
Lopez et al., 2001; Maroof e Kaye, 2008) e independentes da produção de IL-12 (Soares et al., 2007).

\subsection{Direcionando antígenos para as populações de DCs $\mathrm{CD8}^{+} \mathrm{DEC}^{-05}{ }^{+}$e $\mathrm{CD8}^{-} \mathrm{DCIR2}{ }^{+}$.}

As vacinas desenvolvidas e utilizadas atualmente induzem potente resposta humoral, mas existe ainda enorme dificuldade no desenvolvimento de estratégias vacinais capazes de gerar uma resposta protetora mediada por uma resposta celular dependente de Linfócitos $\mathrm{T}$. Tais vacinas seriam de extremo interesse, principalmente para o combate de infecções em que a resposta humoral isolada parece ser insuficiente, como: HIV1/AIDS, tuberculose, malária, leishmanioses, e especula-se até mesmo sua utilidade no combate a certos tipos de câncer (Trumpheller et al., 2011). A descrição recente de outro grupo de linfócitos T, os Linfócitos T reguladores, e a possibilidade de manipulação das respostas deste grupo de células, suscitam ainda possibilidade de atuação vacinal no combate a outros tipos de patologias, como alergias, rejeição de transplantes, autoimunidade, inflamações crônicas e arteroesclerose (Hermansson et al., 2010). O conhecimento sobre a biologia das células dendríticas, em franca expansão, tem permitido o desenvolvimento de estratégias vacinais baseadas na capacidade destas células de modular as respostas imunes adaptativas, inclusive e principalmente aquelas baseadas em Linfócitos T (Trumpheller et al., 2011).

Embora a vacinação utilizando proteínas, complexos protéicos, ou subunidades de proteínas tenha potenciais vantagens - custo, segurança, facilidade de produção - em relação a outros tipos de vacina, normalmente estes protocolos apresentam problemas de baixa imunogenicidade para células $\mathrm{T}$, mesmo quando altas doses são repetidamente administradas. No entanto, recentemente, alguns grupos de cientistas têm desenvolvido técnicas para tornar tais protocolos de vacinação baseados em proteínas mais imunogênicos, em especial graças a duas descobertas.

A primeira foi a descrição de novos marcadores moleculares para DCs, que foram em seguida melhor estudados, e verificou-se sua capacidade de mediar, in vivo, a captação, o processamento e a apresentação de antígenos. O primeiro destes marcadores descritos foi o antígeno CD205, ou DEC205 (Jiang et al., 1995), e a ele se seguiram outros como DC-SIGN (Geijtenbeek et al., 2000) e DCIR2 (Flornes et al., 2004). A partir deste conhecimento, surgiu a possibilidade de se direcionar proteínas diretamente para DCs através destes receptores, aumentando a apresentação de antígenos para linfócitos $\mathrm{T} \mathrm{CD}^{+}$e $\mathrm{CD} 8^{+}$tanto em animais quanto em humanos. 
A segunda descoberta foi uma nova classe de receptores inatos, descritos primeiramente em moscas, os receptores Toll (Lemaitre et al., 1996), capazes de desencadear um complexo de sinalizações intracelulares que estimulam a maturação de alguns tipos de células, auxiliando na resposta imune nestes insetos. A esta descoberta seguiu-se a identificação e descrição de receptores semelhantes em mamíferos, os receptores semelhantes a Toll - ou TLRs (Medzhitov et al., 1997; Poltorak et al., 1998; Hoshino et al., 1999; Qureshi et al., 1999). À sua descoberta, seguiram-se estudos identificando os diversos TLRs e os seus ligantes exógenos correspondentes, em geral componentes microbiais e moléculas que os mimetizassem (Takeushi et al., 1999; Hemmi et al., 2000). A literatura científica demonstra a capacidade dos TLRs de sinalizar para a produção de citocinas e quimiocinas por diversos tipos celulares e, no caso das DCs, havia a partir daquele momento uma forma em potencial de sinalizar para a maturação destas células através de compostos exógenos específicos.

Este conhecimento levantou a possibilidade de se direcionar antígenos para DCs através de receptores específicos, e simultaneamente induzir a maturação destas células pela administração de ligantes de TLRs, garantindo uma captura e processamento adequados dos antígenos de interesse, para que fossem apresentados para Linfócitos $\mathrm{T} \mathrm{CD}^{+}$e $\mathrm{CD} 8^{+}$num contexto de inflamação (Trumpheller et al., 2011).

O direcionamento de antígenos para DCs utilizando o anticorpo $\alpha$ DEC205 foi inicialmente descrito por Hawiger et al. (2001) e Bonifaz et al. (2002). Nesses estudos iniciais, o anticorpo $\alpha \mathrm{DEC}$ foi conjugado ou fusionado diretamente a antígenos modelo como a ovalbumina (OVA) e lisozima de ovo de galinha (HEL). A administração desses anticorpos híbridos ( $\alpha$ DEC-OVA e $\alpha$ DEC-HEL) foi capaz de direcionar os antígenos à população de DCs $\mathrm{CD}^{+} \mathrm{DEC} 205^{+}$in vivo. Os antígenos foram então eficientemente processados e apresentados tanto para células $\mathrm{T} \mathrm{CD}^{+}$quanto para células $\mathrm{T} \mathrm{CD}^{+}$transgênicas. A apresentação de antígenos do meio extracelular para linfócitos $\mathrm{T} \mathrm{CD} 8^{+}$por células dendríticas - denominado cross-priming - é um fenômeno descrito para a captação de antígenos de células apoptóticas por APCs (Albert et al., 1998), e que vem sendo estendido para outros contextos.

$\mathrm{Na}$ ausência de inflamação induzida por ligantes de TLR, o direcionamento de antígenos resultou na indução de tolerância periférica, observada pela deleção de células $\mathrm{T}$ transgênicas específicas para o antígeno utilizado. Entretanto, quando os anticorpos foram administrados na presença de um estímulo de maturação para as DCs, como o anticorpo agonista $\alpha \mathrm{CD} 40$, houve ativação prolongada de células $\mathrm{T} \mathrm{CD}^{+}$e $\mathrm{CD}^{+}$. Além disso, a 
imunidade induzida foi de longa duração e mais efetiva do que a induzida pela administração da proteína não-direcionada na presença de potentes adjuvantes como o adjuvante completo de Freund (Hawiger et al., 2001; Bonifaz et al., 2002). Dando continuidade a esses estudos, o mesmo grupo mostrou que camundongos vacinados com o anticorpo $\alpha$ DEC-OVA na presença de $\alpha \mathrm{CD} 40$ tornaram-se resistentes a infecção pelo vírus vaccínia transgênico expressando OVA (Bonifaz et al., 2004). Além disso, a imunização de animais com o mesmo anticorpo promoveu a ativação de células $\mathrm{T} \mathrm{CD}^{+}$de memória (Boscardin et al., 2006), importantes para a ativação de linfócitos B antígeno específicos.

Os estudos citados acima abriram a possibilidade de se utilizar anticorpos híbridos aDEC205 conjugados a antígenos clinicamente relevantes para a indução de imunidade protetora contra diferentes doenças prevalentes.

A primeira doença escolhida foi a AIDS, e a proteína Gag do HIV foi fusionada ao anticorpo $\alpha$ DEC205, uma vez que haviam evidências de que respostas imunes mediadas por células $\mathrm{T}$ contra essa proteína continham pelo menos alguma capacidade protetora (Zuniga et al., 2006; Edwards et al., 2002).

$\mathrm{O}$ anticorpo $\alpha \mathrm{DEC}-\mathrm{Gag}$ foi administrado em uma única dose na presença de Poly I:C e $\alpha \mathrm{CD} 40$ em camundongos, e observou-se uma resposta melhor quando Gag era direcionada, do que quando era administrada em fusão com um anticorpo inespecífico, Iso-Gag (Trumpfheller et al., 2006). Neste mesmo estudo, observou-se que diversos peptídeos foram apresentados a múltiplos tipos de MHC de camundongos, que a resposta induzida era duradoura, e que os camundongos imunizados resistiam a um desafio utilizando um vírus quimérico Vaccinia-Gag. No entanto, a utilização de $\alpha \mathrm{CD} 40$ em humanos é controversa, e o uso de Poly I:C como único adjuvante foi testado em seguida, com resultados aquém do esperado quando foi administrada uma única dose, mas satisfatórios quando uma segunda dose, idêntica a primeira, de $\alpha$ DEC-Gag + Poly I:C foi injetada. Após a administração da segunda dose houve inclusive a indução de linfócitos $\mathrm{T} \mathrm{CD} 4^{+}$poli-funcionais (produtores de diversas citocinas simultaneamente) específicos para peptídeos da proteína Gag e persistentes por pelo menos 7 semanas (Trumpfheller et al., 2008).

Embora este estudo não tenha observado resposta apreciável por Linfócitos T $\mathrm{CD}^{+}$ nos camundongos imunizados, um outro trabalho, avaliando a capacidade de DCs apresentarem o antígeno Gag direcionado in vitro via $\alpha$ DEC-Gag para Linfócitos $\mathrm{T}$ de indivíduos infectados pelo HIV, observou a ativação de Linfócitos T $\mathrm{CD}^{+}$destes pacientes, no contexto de diferentes classes de MHCI. Mas, uma vez que estes linfócitos já se 
encontravam primados, denominou-se o fenômeno observado de cross-presentation (Bozzacco et al., 2007). Um estudo mais recente observou o mesmo fenômeno ocorrendo em camundongos, inclusive quando a proteína Gag foi direcionada para outros receptores da mesma população de DCs CD8 ${ }^{+} \mathrm{DEC} 205^{+}$, como os receptores Langerina e CLEC9A, ou para o DEC205 (Idoyaga et al., 2011). Este estudo nos permite analisar que os efeitos observados não se devem exclusivamente ao receptor para qual o direcionamento é realizado, mas também, e talvez principalmente, à subpopulação de DCs que expressam o receptor específico do anticorpo quimérico utilizado.

O direcionamento com $\alpha$ DEC utiliza-se de uma única subpopulação de DCs, $\mathrm{CD}^{+}{ }^{+} \mathrm{DEC} 205^{+}$. Contudo, outras populações de DCs podem ser alvo desta estratégia de direcionamento, como é o caso das DCs CD8DCIR2 ${ }^{+}$, que expressam o receptor DCIR2, alvo do anticorpo específico denominado 33D1. Estudos comparativos utilizando anticorpos $\alpha$ DEC-OVA e 33D1-OVA, demonstraram que quando direciona-se antígenos para cada uma destas populações na presença de Poly I:C, observa-se diferenças significavas entre o tipo de resposta celular desenvolvida, sendo que o direcionamento para DCIR2 mostrou-se mais eficiente na apresentação de antígenos para Linfócitos $\mathrm{T} \mathrm{CD}^{+}$, enquanto o direcionamento para DEC205 foi superior na indução de resposta por Linfócitos T CD8 ${ }^{+}$(Dudziak et al., 2007).

Um estudo similar, utilizando anticorpos quiméricos fundidos à proteína LACK de Leishmania major, corroborou os dados prévios de que ambas populações de DCs são capazes de induzir uma resposta de Linfócitos $\mathrm{T} \mathrm{CD}^{+}$, sendo 33D1 mais eficiente que $\alpha \mathrm{DEC}$. Contudo, ao analisar o perfil de citocinas induzido nestas células, observou-se um perfil mais Th1 induzido pelo direcionamento para o receptor DEC205, com maior número de células produtoras de IFN- $\gamma$ induzidas quando o antígeno é direcionado para a população de dendríticas que expressam este receptor (Soares et al., 2008).

Em outros estudos envolvendo proteínas de outros patógenos relevantes, Boscardin et al. (2006) utilizaram o anticorpo $\alpha \mathrm{DEC} 205$ fusionado à proteína circunsporozoíta (CS) expressa no estágio pré-eritrocítico de desenvolvimento do Plasmodium yoelii, agente causador da malária murina. A administração de uma única dose do anticorpo quimérico aDEC-CS, na presença de um estímulo de maturação para as DCs, foi capaz de induzir células $\mathrm{T} \mathrm{CD}^{+}$e $^{\mathrm{CD}} 8^{+}$produtoras de INF- $\gamma$ em diferentes linhagens de camundongos. Além disso, a indução de resposta imune humoral também foi observada após a administração de uma dose de reforço do anticorpo, na ausência de qualquer outro adjuvante. 
Em outro trabalho, macacos Rhesus foram imunizados com o anticorpo $\alpha$ DEC205 fusionado à proteína CS de P. falciparum na presença de Poly I:C. Observou-se a indução de células $\mathrm{T} \mathrm{CD}^{+}$poli-funcionais e a produção de anticorpos anti-CS com características neutralizantes, capazes de bloquear em cerca de $43 \%$ a invasão de eritrócitos pelo $P$. falciparum in vitro (Tewari et al., 2010).

Mais recentemente, a imunização de primatas com o anticorpo $\alpha$ DEC205 fusionado à proteína Gag, seguida de um reforço utilizando um vírus vaccínia codificando as proteínas Gag, Pol e Nef do HIV, foi capaz de induzir forte resposta celular (Flynn et al., 2011).

Além dos ensaios utilizando proteínas do vírus HIV e de Plasmodium, a estratégia de direcionar antígenos utilizando os anticorpos $\alpha$ DEC205 e 33D1 foi testada com um antígeno derivado da bactéria Yersinia pestis (agente causador da peste pneumônica). Quando a proteína LcrV foi fundida ao anticorpo $\alpha$ DEC205 e administrada a camundongos na presença de estímulos de maturação para as DCs, forte resposta imune celular foi induzida (Do et al., 2008). Além disso, observou-se a indução de resposta humoral com níveis de anticorpos semelhantes àqueles induzidos pela vacina comercial. Da mesma forma, a proteína LcrV direcionada para o receptor DCIR2 foi capaz de induzir proteção contra desafio utilizando uma cepa virulenta (Do et al., 2010).

Além de experimentos in vivo utilizando camundongos e macacos, o anticorpo aDEC205 também foi utilizado com sucesso para direcionar antígenos para as DCs de humanos in vitro. Bozzacco et al. (2007) mostraram que ocorreu ativação de linfócitos T $\mathrm{CD}^{+}$e produção de INF- $\gamma$ quando o anticorpo híbrido $\alpha$ DEC205 fusionado à proteína Gag do vírus HIV foi incubado com DCs provenientes de pacientes soropositivos, e depois reestimuladas com as células $\mathrm{T}$ autólogas. Gurer et al. (2008) obtiveram resultados semelhantes quando utilizaram um anticorpo $\alpha \mathrm{DEC}$ humano em fusão com o antígeno EBNA-1 do vírus Epstein-Barr.

Novos anticorpos $\alpha$ DEC205 humano foram gerados e selecionados por sua capacidade de reconhecer com alta afinidade o receptor DEC205. Esses anticorpos foram fusionados à proteína Gag de HIV e observou-se a indução de ampla resposta celular quando camundongos transgênicos expressando o DEC205 humano foram utilizados em ensaios de imunização (Cheong et al., 2010). Mais interessante ainda foi o fato de que esses anticorpos, assim como o anticorpo utilizado por Bozzaco et al. (2007), foram também capazes levar à estimulação de células $\mathrm{T} \mathrm{CD}^{+}$in vitro. 
Os resultados pré-clínicos obtidos com o anticorpo $\alpha \mathrm{DEC}$-Gag foram tão promissores que testes clínicos de fase I foram iniciados no primeiro semestre de 2010 (http://www.clinicaltrials.gov, identificador NCT01127464) com objetivo de verificar a segurança, tolerabilidade e imunogenicidade do anticorpo $\alpha$ DEC-Gag em indivíduos saudáveis .

\subsection{Receptores de Padrões de Patógenos e seu papel nos inflamossomos.}

Os inflamossomos foram recentemente descritos como sendo um tipo integrado de resposta imune que envolve simultaneamente diferentes classes de Receptores de Padrões de Patógenos (PRRs). Estes complexos sistemas de sinalização estão sendo amplamente estudados e parecem ser importantes para a promoção de uma resposta pró-inflamatória mais eficiente, através da clivagem proteolítica de precursores de citocinas inflamatórias, entre outras ações (Martinon et al., 2009).

Os PRRs são atualmente constituídos por 3 grupos de proteínas que estão presentes em DCs, macrófagos e em alguns outros tipos celulares, e que são capazes de reconhecer os mais diversos padrões moleculares de patógenos. Os Receptores Semelhantes a Toll (TLRs) constituem o grupo mais conhecido de PRRs e vêm sendo estudados há algum tempo como potentes ativadores do sistema imune. Até o momento, 12 membros desta família foram descritos em mamíferos (TLRs 1 a 12) sendo que alguns estão presentes na superfície das células enquanto outros são intracelulares (Kumar et al., 2009). Os dois outros grupos citados são: os Receptores Semelhantes a NOD (NLRs) e as Helicases Semelhantes a RIG-1 (RLHs). Estes grupos compreendem proteínas citosólicas que seriam capazes de identificar padrões de patógenos que venham a atingir o citosol da célula (Kumagai et al., 2008).

Diferentes ligantes de TLRs vêm sendo testados como adjuvantes. No caso da imunização utilizando-se os anticorpos quiméricos, o ligante sintético do TLR3 conhecido como Poly I:C ("polyriboinosinic:polyribocytidylic acid") mostrou-se bastante promissor. A administração de duas doses do anticorpo quimérico $\alpha$ DEC-GAG juntamente com o Poly I:C foi capaz de induzir uma resposta de células $\mathrm{T} \mathrm{CD}^{+}$bastante duradoura e protetora (Trumpfheller et al., 2008). Além disso, quando Poly I:C ou um análogo do Poly I:C (Poly ICLC) foi utilizado em conjunto com capsômeros do vírus HPV ("human pappiloma vírus") em macacos Rhesus, observou-se a indução de forte resposta imune humoral e celular do tipo Th1 contra o mesmo (Stahl-Hennig et al., 2009). Interessantemente, o Poly I:C tem ainda uma segunda sinalização, que se dá via receptor citosólico MDA5 (Melanoma Differentiation- 
Associated Gene 5). Em 2007, Trumpfheller et al. demonstraram a importância desta via na sinalização via Poly I:C, visto que camundongos nocaute para o receptor TLR3 ainda exibiam resposta significativa, mas menor que camundongos selvagens, a estímulos com este ligante. Estudos mais recentes do mesmo grupo demonstraram a importância da sinalização deste adjuvante pelo receptor MDA5, demonstrando que a sinalização por este receptor em tipos celulares diversos induz um aumento sistêmico dos níveis de Interferons tipo I, que parecem ser importantes na indução da maturação de DCs e na indução de respostas Th1 por Linfócitos T CD4 ${ }^{+}$(Longhi et al., 2009). Outros agonistas de TLRs diversos foram testados neste estudo, e assim como nenhum foi eficiente na indução de Interferons tipo I, nenhum foi tão eficiente quanto Poly I:C na indução da maturação de DCs.

CpG oligodeoxinucleotídeos não metilados ligam-se ao receptor TLR9 e vêm sendo testados com relativo sucesso como adjuvantes para vacinas contra diversas doenças infecciosas. A administração de CpGs induz resposta do tipo Th1 e produção de citocinas próinflamatórias, além da ativação e maturação de DCs, particularmente DCs plasmocitóides (Klinman et al., 2009). Em seres humanos, CpGs já foram utilizados em alguns ensaios clínicos em conjunto com vacinas contra hepatite B (Halperin et al., 2003), gripe (Klinman et al., 2000) e malária (Ellis et al., 2009). Os resultados descritos indicam que a inclusão de CpGs nas formulações vacinais melhorou em diversos aspectos a resposta imune.

Já o agonista MDP ("muramyl dipeptide") é um composto da parede celular das mais diversas bactérias que é reconhecido pelos NLRs NOD2 e NALP3. Sua ligação aos NLRs leva a produção de IL-1 $\beta$ (Martinon et al., 2009). A imunização de cachorros com uma formulação contendo antígenos solúveis de Leishmania infantum juntamente com MDP foi capaz de conferir 100\% de proteção após o desafio (Lemestre et al., 2005). Além disso, certo grau de proteção também foi observado contra esquistossomose, quando primatas foram imunizados com uma combinação de glutationa-S-transferase+MDP (Boulanger et al., 1995).

Como descrito acima, os inflamossomos são formados quando ocorre a ativação de TLRs, sua internalização e a concomitante ativação de NLRs/RLHs no citosol. É a interação entre estas proteínas que é capaz de promover a maturação de células apresentadoras de antígenos (especialmente as DCs) que vão orquestrar a ativação de respostas imunes eficientes (Benko et al., 2008). Por este motivo, a utilização concomitante de um agonista capaz de ativar TLRs (Poly I:C ou CpG, por exemplo) com um agonista capaz de ativar NLRs, como é o caso do MDP, surge como uma alternativa interessante para maturação das DCs e indução de uma resposta pró-inflamatória contra o patógeno de interesse. 


\subsection{A dengue e a NS-1.}

A dengue é uma doença típica de regiões tropicais e sub-tropicais, que reportam cerca de 50 a 100 milhões de casos anualmente, sendo que até 500.000 destes casos evoluem para a forma hemorrágica da doença, resultando em mais de 20.000 mortes (Guzmán e Kouri, 2002). Embora até 1970 apenas cinco países do sudeste asiático houvessem reportado casos das formas mais severas da doença (Gubler, 1998), atualmente já existem relatos em mais de 60 países, de pelo menos quatro continentes (WHO, 1997). Diversos estudos publicados recentemente reiteram sua emergência e ressurgência (Kyle e Harris, 2008; Wilder-Smith et al., 2010; Mackenzie et al., 2004). Atualmente, a dengue é a infecção arboviral mais comum em humanos nas regiões tropicais e subtropicais do planeta (Thomas e Endy, 2011).

A doença é causada pelo vírus da dengue (DENV) e existem 4 sorotipos relacionados: DENV-1, DENV-2, DENV-3 e DENV-4 (Lindenbach e Rice, 2001), sendo que DENV2 e DENV4 parecem estar menos relacionados com as formas mais severas da doença em infecções primárias (Fried et al., 2010). Cada vírus é composto de um RNA simples, positivo, e com cerca de $11 \mathrm{~Kb}$, que é transcrito em uma única fase de leitura e traduzido numa poliproteína, que é então processada por proteases do vírus e do hospedeiro para produzir três proteínas que compõem a partícula viral - capsídio (C), pré-membrana/membrana (prM/M) e envelope (E) - e sete outras proteínas não-estruturais - NS1, NS2a, NS2b, NS3, NS4a, NS4b, NS5 (Lindenbach e Rice, 2001). A síntese da poliproteína ocorre no retículo endoplasmático rugoso, e regiões de ancoragem à membrana direcionam a topologia da poliproteína, sendo que as proteínas prM, E e NS1 se projetam para o lúmen do retículo, onde a montagem e maturação do vírus ocorrem (Murphy e Whitehead, 2011).

A origem do vírus parece ser de um flavivírus africano, que evoluiu independentemente em quatro vírus distintos ao longo dos últimos 1000 anos (Holmes e Twiddy, 2003). Estimativas indicam que a transição da transmissão do DENV, de selvática para sustentada e humana, foi um evento recente, ocorrido entre 320 e 125 anos atrás, sendo que a pandemia global atual dos 4 tipos de vírus ocorreu durante o último século (Twiddy e Holmes, 2003). A evolução do DENV, que se replicava numa população imunologicamente adaptada a outros flavivírus - devido a outras infecções por DENV, ou resultado de infecções pelo vírus da febre amarela, ou pelo vírus da encefalite japonesa - causou a adaptação do vírus de uma forma única, de tal forma que este se tornou capaz de escapar de anticorpos neutralizantes heterotípicos (NAb) e de utilizar-se de anticorpos anti-DENV pré-existentes para amplificar sua própria infecção, um mecanismo conhecido como amplificação 
dependente de anticorpo (do inglês, antibody-dependent enhancement ou ADE). Isto criou um vírus que eventualmente produziu quadros clínicos ainda mais graves, como a febre hemorrágica e a síndrome do choque da dengue, observada pela primeira vez em 1950 (Halstead et al., 1963 apud Thomas e Endy, 2011).

A evasão imune é uma característica do DENV, sendo este capaz de inibir a produção dos IFN- $\alpha$ e IFN- $\beta$ pelas DCs humanas (Rodriguez-Madoz et al., 2010a e Rodriguez-Madoz et al., 2010b). As proteínas não-estruturais (NS2a, NS4a, NS4b e NS5) são importantes no antagonismo das vias de sinalização de IFNs, tendo sido demonstrada a capacidade de NS5 de se ligar a STAT2, reduzindo sua expressão, que é essencial para a sinalização por IFNs (Ashour et al., 2009). É comumente aceito que após a liberação na derme, pelo mosquito em repasto, o DENV se replica localmente em células dendríticas (Palucka, 2000 e Boonnak et al., 2008), e num segundo momento, quando da chegada na circulação, infecta sistemicamente macrófagos/monócitos (Blackley et al., 2007 e Kou et al., 2008). Outros tipos celulares, principalmente hepatócitos, podem ser infectados, sem manifestações clínicas decorrentes deste fato, exceto nos casos mais graves e de maior viremia (Jessie et al., 2004).

A proteína E, responsável pela interação do vírus com a célula hospedeira, é suscetível a ação de anticorpos neutralizantes (NAb) e, por este motivo, é o principal alvo de estratégias vacinais. No entanto, concentrações sub-neutralizantes destes anticorpos podem ser responsáveis por mediar o fenômeno de ADE, e acredita-se que sejam importantes na patogênese de formas mais severas da doença (Thomas e Endy, 2011). Outros estudos recentes demonstraram que a capacidade da proteína E de se ligar a anticorpos DENVespecíficos é utilizada pelo vírus, não somente para invadir células que expressam o receptor Fc, mas também para evadir o sistema imune, invadindo monócitos (Ubol et al., 2010). Estes complexos ativam reguladores negativos da produção de interferons tipo 1 e estimulam a produção de IL-10, que diminui respostas antivirais secundárias, como a produção de radicais de óxido nítrico (Ubol et al., 2010).

Uma infinidade de fatores do hospedeiro (tipo de HLA, idade, sexo, outras infecções, perfil de respostas celular e humoral anti-DENV pré-existentes, ...) e do vírus (tipo de DENV, genótipo do DENV, sequência de infecções, ...) já foram propostos para explicar o grande espectro de formas clínicas da doença, que variam de subclínica a severa (Imrie et al., 2010; Rothman, 2010 e Rothman et al., 1997). Há considerável evidência de que após a primeira infecção (infecção primária), a resposta do hospedeiro promove um período variável (2 a 6 meses) de proteção a infecções subsequentes (homotípicas e heterotípicas) e um período longo (décadas) de proteção a re-infecções homotípicas (Endy et al., 2010). Contudo, ainda 
não está claro exatamente o que constitui uma resposta imune protetora e uma resposta imune imunopatogênica após a infecção por DENV. Por outro lado, são consistentes os dados que demonstram clinicamente que as formas de infecção mais severas não ocorrem em indivíduos expostos a uma primeira infecção, mas em contextos de re-infecções heterotípicas (Halstead, 1966; Halstead, 1970 e Halstead et al., 2010).

A OMS considera a prevenção da Dengue como uma área de pesquisa prioritária (WHO, 2010), e a despeito do longo tempo de pesquisas sobre o tema, ainda não se definiu com clareza o tipo de resposta desejado para uma vacina ideal contra DENV. Este quadro se agrava principalmente pela falta de bons modelos murinos e primatas de infecção por DENV para testes iniciais e pela literatura conflitante, tanto sobre as origens das formas mais severas da doença (síndrome do choque - DSS - e dengue hemorrágica - DHF), quanto sobre possíveis interações entre as imunizações e a facilitação destes quadros (Miller, 2010).

Sabe-se que anticorpos gerados numa infecção podem facilitar a infecção celular de outro sorotipo do vírus através do receptor de Fc, o que caracteriza o fenômeno de ADE (Tan e Alonso, 2009). Por outro lado, a ativação, em uma reinfecção heterotípica, de células T de memória com baixa afinidade pelo novo sorotipo, pode resultar em diversas complicações, inclusive a liberação anormal de citocinas, a eliminação incompleta do vírus, apoptose e extravasamento de líquido vascular (Tan e Alonso, 2009). Além disso, a sequência em que ocorrem as infecções também parece determinar tipos distintos de respostas celulares protetoras ou que agravem o quadro clínico (Beaumier e Rothman, 2009). Por todas estas razões, sabe-se que a vacina com potencial para uso clínico em humanos deve ser tetravalente, ou seja, deve promover proteção duradoura contra todos os sorotipos simultaneamente.

Existem dois tipos principais de abordagem na busca deste tipo de vacina tetravalente. O primeiro envolve a apresentação de antígenos específicos de cada um dos quatro sorotipos numa mesma vacina. O segundo envolve a apresentação de um ou mais antígenos que sejam relativamente constantes entre os quatro sorotipos. Mais importante, qualquer destas abordagens deve induzir uma imunidade balanceada contra todos os sorotipos, o que pode ser dificultado, especialmente no primeiro tipo, por eventos como interferência viral, imunodominância, apresentação desbalanceada dos antígenos e em ambas abordagens, por variações genéticas do vírus (Miller, 2010).

Também é complexo o entendimento acerca do tipo de resposta desejável em uma vacina contra o DENV. A infecção por DENV aparentemente gera populações heterogêneas de Linfócitos $\mathrm{T}$ específicos, que podem tanto exacerbar o quadro clínico observado quanto contribuir para a eliminação do vírus (Thomas et al., 2009). Infecções primárias parecem 
gerar uma resposta celular significativa em murinos. Em um modelo de infecção de camundongos por uma cepa de DENV2, foi observada resposta específica de Linfócitos T $\mathrm{CD}^{+}$contra 12 epitopos de seis proteínas do DENV, e a depleção deste tipo celular se correlaciona com um aumento da viremia, enquanto a imunização com os epitopos específicos para células $\mathrm{T} \mathrm{CD}^{+}$favoreceu a eliminação do vírus (Yauch et al., 2009). Em outro estudo do mesmo grupo, identificou-se também pelo menos 4 epitopos de 3 proteínas do vírus e, embora esta resposta não pareça ser importante na indução das respostas mediadas por Linfócitos $\mathrm{T} \mathrm{CD}^{+}$ou por Linfócitos $\mathrm{B}$, parece contribuir para a proteção conferida pela imunização (Yauch et al., 2010). Um outro estudo identificou um peptídeo de 9 aminoácidos da proteína NS1, específico para Linfócitos $\mathrm{CD}^{+}$, e conservado entre os 4 sorotipos, capaz de induzir respostas citotóxicas eficazes (Gao et al., 2008).

Mais estudadas que as respostas celulares são as respostas humorais geradas por diferentes protocolos de imunização, embora tal estudo seja dificultado pela variedade de cepas e genótipos existentes dentro de cada sorotipo (Kyle e Harris, 2008). Sabe-se que a maior parte dos anticorpos no soro de humanos infectados por DENV reconhecem o domínio DII da proteína E, que é o domínio classicamente relacionado a eventos de ADE. Os anticorpos específicos que reconhecem o domínio DIII da proteína E são cerca de $1 \%$ da resposta humoral observada, sendo estes anticorpos classicamente relacionados com a capacidade de neutralização do vírus (Crill et al., 2009). Outro estudo avaliou que a depleção da maior parte dos anticorpos DIII específicos do soro humano não diminuiu significativamente a capacidade de neutralização deste (Wahala et al., 2009). Este resultado indica que ou os anticorpos anti-DIII não são os mediadores principais de neutralização do DENV, ou que baixos níveis de anticorpos anti-DIII sejam suficientes para neutralizar o vírus da dengue. Como este estudo não depletou os epitopos inter-domínios, supõe-se, ainda, que estes possam também ser capazes de mediar a neutralização do vírus (Wahala et al., 2009).

Além da $\mathrm{ADE}$ já descrita, outras reações podem ser observadas em função de respostas humorais ao DENV. Anticorpos contra a proteína NS1 podem apresentar reaçãocruzada com plaquetas (Chen et al., 2009), ou causar apoptose de células endoteliais (Lin et al., 2003), o que poderia contribuir para o extravasamento de líquido vascular através de ambos mecanismos. Estes eventos podem ser resolvidos pelo truncamento da proteína NS1, retirando-se sua porção C-terminal (Chen et al., 2009).

Uma vacina tetravalente baseada em uma sequência consenso do domínio DIII da proteína $\mathrm{E}$ de 15 cepas distintas de cada um dos quatro sorotipos foi capaz de induzir anticorpos anti-DIII capazes de neutralizar os 4 sorotipos do vírus em um modelo murino 
(Ramanathan et al., 2009). A expressão do domínio DIII dos quatro sorotipos em uma única sequência sugere níveis de expressão semelhantes para todos eles, favorecendo uma resposta imune balanceada contra todos.

Além de vacinas de DNA, diversas vacinas baseadas em subunidades de proteínas do vírus vem sendo produzidas e testadas, principalmente focadas no domínio DIII da proteína E. Em um estudo, foi desenvolvida uma proteína utilizando-se o consenso nas regiões do domínio DIII da proteína E nos quatro sorotipos. A proteína resultante, quando injetada em camundongos, foi capaz de induzir anticorpos neutralizantes contra todos os quatro sorotipos, mas a resposta contra DENV4 foi mais baixa que as demais, o que poderia sugerir um risco de ADE (Leng et al., 2009).

Sabe-se que a infecção de humanos por DENV resulta no desenvolvimento de respostas específicas de células $\mathrm{T} \mathrm{CD}^{+}$e $\mathrm{CD} 8^{+}$conta o vírus, que reconhecem epitopos presentes em diversas proteínas do vírus, mas principalmente das proteínas não-estruturais (Mathew e Rothman, 2008). As respostas de células T foram caracterizadas, e podem ter um papel na patogênese da dengue em infecções secundárias (Mathew e Rothman, 2008). Uma resposta específica $\mathrm{T} \mathrm{CD}^{+}$ocorre durante infecções secundárias e é caracterizada pela aquisição de marcadores de ativação, proliferação e altos níveis de apoptose (Myint et al., 2006). As células $T$ heterotipicamente reativas exibem degranulação sub-ótima, mas alta secreção de citocinas (Mongkolsapaya et al., 2006). A magnitude da resposta específica de células $\mathrm{T} \mathrm{CD}^{+}$parece correlacionar-se com a severidade do quadro clínico da doença (Mongkolsapaya et al., 2006; Mongkolsapaya et al., 2003 e Mangada et al., 2002). Contudo, o número de pacientes nestes estudos foi baixo demais para estabelecer um papel patogênico independente para a resposta de células $\mathrm{T}$ durante infecções secundárias. A interpretação de tais associações é complicada pela observação de que os quadros clínicos graves da doença são claramente associados à magnitude de replicação viral, e espera-se que esta alta carga de antígeno induza respostas robustas de células T (Murphy e Whitehead, 2011). Portanto, estabelecer uma contribuição das células T para a proteção ou para o agravamento da infecção necessitaria de uma ampla amostragem, junto a uma análise quantitativa de múltiplos parâmetros virológicos e imunológicos para definir o papel de qualquer fator para o quadro clínico final da infecção. Tais estudos vêm sendo realizados e têm gerado suporte para a hipótese de que células $\mathrm{T}$ de memória específicas para o DENV geradas em uma primeira infecção podem representar um fator determinante da severidade da doença (Murphy e Whitehead, 2011). Há evidências de que, numa infecção heterotipica secundária, células T de memória existentes são reativadas ao novo sorotipo. Esta resposta heterotipica pode ser 
exacerbada em algumas células $\mathrm{T}$ e resultaria numa liberação excessiva de citocinas inflamatórias. Alternativamente, algumas células $\mathrm{T}$ de memória poderiam sofrer de uma sinalização distinta, que resultaria em uma falha na sua capacidade citotóxica em relação às células infectadas por DENV e uma consequente compensação, com a produção de uma quantidade ainda maior de citocinas (Rothman, 2009). Estas respostas poderiam resultar em efeitos diretos e indiretos que levariam a um aumento da permeabilidade vascular e, consequentemente, a formas mais severas da doença.

Alguns modelos para avaliar a importância destas respostas celulares utilizam vetores virais (quimeras) para apresentar diferentes proteínas do DENV. Estudos utilizando Vírus West Nile (Suzuki et al. 2009) e Vírus da Febre Amarela (Guy et al., 2009) modificados para expressar proteínas do DENV mostraram indução de resposta imune humoral neutralizante e proteção contra desafios em camundongos e primatas, respectivamente. O modelo utilizando Vírus da Febre Amarela esta atualmente em estágio de testes clínicos em voluntários que já respondem a algum tipo de flavivírus ou que nunca tiveram contato com estes, sendo que neste último grupo a resposta humoral contra o sorotipo DENV4 foi insatisfatória, sendo corrigida com uma segunda dose, 4 meses após a primeira (Guy et al., 2008).

Em outro estudo, a proteína $\mathrm{C}$ recombinante foi utilizada e induziu proteção em camundongos. Como o capsídeo não encontra-se exposto, a resposta foi principalmente celular, e o estudo demonstrou que esta preparação induziu a liberação de IFN- $\gamma$ por linfócitos $\mathrm{T} \mathrm{CD}^{+}$e CD8 ${ }^{+}$. Ainda reforçando esta teoria, a depleção de células T neste modelo reduziu a taxa de sobrevivência ao desafio (Gil et al., 2009). Este trabalho soma-se a outros que utilizaram proteínas não expostas do vírus, as proteínas não estruturais (Chen et al., 2009 e Gao et al., 2008), para indicar que uma resposta imune celular poderia, por si só, prover imunidade ao vírus da dengue, além de corroborarem outros estudos que demonstram a importância da resposta celular ao DENV em murinos (Yauch et al., 2009 e Yauch et al., 2010).

Células T CD8 ${ }^{+}$e $C D 4^{+}$específicas contra DENV que são induzidas por uma infecção parecem representar um papel moderado na eliminação do vírus e na proteção contra a infecção experimental em camundongos (Kyle et al., 2008; Yauch et al., 2009; Yauch et al., 2010 e Gil et al., 2009). Além disso, dados demonstram que crianças amamentadas até 6 meses de idade em áreas endêmicas são pouco suscetíveis a formas severas de infecção por DENV, sendo que a susceptibilidade aumenta dos 6 aos 12 meses, mesmo para uma infecção primária, decaindo em seguida (Halstead et al., 2002; Kliks et al., 1988 e Nguyen et al., 2004). Interpreta-se usualmente estes dados para concluir que provavelmente os anticorpos 
neutralizantes maternos anti-DENV transferidos para o bebê nos primeiros meses de vida sejam suficientes para impedir infecções graves. Contudo, com o decaimento dos títulos de anticorpos para concentrações sub-neutralizantes, facilita-se a ocorrência do fenômeno da $\mathrm{ADE}$, resultando em formas severas da doença, mesmo numa primeira infecção, decaindo esta susceptibilidade com o tempo e o desaparecimento dos anticorpos maternos subneutralizantes (Murphy e Whitehead, 2011). Se, de fato, o fenômeno de ADE e a susceptibilidade a formas severas da dengue estão diretamente relacionados a uma presença sub-neutralizante de anticorpos, a resposta celular poderia ser mais segura numa formulação vacinal contra DENV.

A proteína NS1 do DENV é um componente do complexo de replicação do vírus e quando madura é hidrofílica e não possui um domínio de membrana. No entanto, durante a infecção viral, ela é translocada para o retículo endoplasmático e se associa na forma de homodímeros (Falgout et al., 1989; Pryor e Wright, 1993; Winkler et al., 1989). Nas células infectadas, a NS1 dimérica é encontrada associada a proteínas da membrana celular e também secretada na circulação na forma de multímeros (Flamand et al., 1999; Jacobs et al., 2000; Young et al., 2000).

Pacientes infectados com o vírus da dengue produzem anticorpos contra a proteína NS1, embora estes sejam principalmente detectados após a segunda infecção, o que indica uma baixa imunogenicidade humoral desta proteína quando comparada a NS3 ou E (Churdboonchart et al., 1991 e Valdes et al., 2000). A presença da proteína no soro dos indivíduos tem sido utilizada em diferentes testes diagnósticos para detecção precoce da infecção (Ramirez et al., 2009). Estudos demonstraram que anticorpos anti-NS1 de DENV2 seriam capazes de proteger parcialmente animais desafiados num modelo de infecção com DENV2 (Henchal et al., 1988). A indução de proteção, em modelos experimentais animais, também já foi descrita quando a proteína NS1 foi utilizada em protocolos de imunização na forma de DNA (Wu et al., 2003; Timofeev et al., 2004; Costa et al., 2006; e Costa et al., 2007) ou de proteína recombinante (Srivastava et al., 1995). Outros modelos também foram testados, como vírus vaccinia expressando a proteína NS1 recombinante, e também observaram proteção dos camundongos ao desafio com DENV (Falgout et al., 1990). Porém, um estudo recente levantou a possibilidade de que anticorpos anti-NS1 inibam a agregação plaquetária (Cheng et al., 2009). O mesmo estudo também mostrou que a deleção da porção C-terminal da NS1 abole a disfunção plaquetária e a tendência a sangramento mediada pelos anticorpos anti-NS1 (Chen et al., 2009). Além disso, a proteína NS1 parece ser também alvo 
da resposta imune adaptativa e um epitopo imunodominante para células $\mathrm{T} C D 8^{+}$foi identificado na linhagem de camundongos BALB/c (Gao et al., 2008).

Em todos os casos analisados, apesar da reação cruzada dos anticorpos anti-NS1 entre sorotipos distintos (DENV1-4), a proteção induzida foi específica para o sorotipo utilizado na produção da proteína recombinante (DENV2), o que sugere que, assim como para a proteína E, uma vacina utilizando NS1 recombinante teria de apresentar a proteína específica de diferentes sorotipos (Murphy e Whitehead, 2011).

Com base nos dados mencionados acima, acreditamos que o estudo do direcionamento da proteína NS1 para diferentes populações de DCs seria de grande utilidade no desenvolvimento de novas estratégias terapêuticas contra o vírus da dengue. 
2. OBJETIVOS 


\subsection{Objetivo Geral}

Analisar as respostas imunes celular e humoral geradas pelo direcionamento da proteína NS1 para as subpopulações de DCs $\mathrm{CD}^{+}{ }^{+} \mathrm{DEC} 205^{+}$ou $\mathrm{CD}^{-} \mathrm{DCIR} 2^{+}$através da injeção dos anticorpos quiméricos $\alpha \mathrm{DEC}$ e 33D1, respectivamente, na presença de diferentes estímulos de maturação para DCs.

\subsection{Objetivos Específicos}

- Clonagem da sequência de DNA da proteína NS1 de DENV2 em fusão com as sequências dos anticorpos $\alpha \mathrm{DEC}$ e 33D1;

- Produção dos anticorpos quiméricos por transfecção transiente de células HEK293T e purificação dos mesmos a partir dos sobrenadantes das culturas;

- Análise da ligação destes anticorpos aos receptores DEC205 e DCIR2 de camundongos;

- Produção das proteínas recombinantes NS1 de DENV2;

- Imunização de camundongos com os anticorpos quiméricos monoclonais produzidos na presença dos adjuvantes poly I:C, CpG e MDP;

- Comparação das respostas imunes celular e humoral geradas após o direcionamento da proteína NS1 para as duas principais populações de células dendríticas presentes no baço;

- Desafio dos animais imunizados com os anticorpos quiméricos contra infecção experimental por DENV2. 
3. MATERIAL E MÉTODOS 


\subsection{Animais.}

Camundongos machos ou fêmeas BALB/c ou C57BL/6 com idades entre 6-8 semanas foram obtidos do Biotério de Camundongos Isogênicos do Departamento de Parasitologia do ICB/USP. Os animais foram mantidos em condições "germ-free" durante o curso dos estudos. Todos os procedimentos utilizados foram aprovados pelo comitê de ética de experimentação animal (CEEA) do Instituto de Ciências Biomédicas da USP (protocolo número 082).

\subsection{Obtenção dos plasmídeos codificando para as cadeias leve e pesada dos anticorpos anti-DEC205 e 33D1.}

Os plasmídeos contendo as cadeias leves e pesadas dos anticorpos foram gentilmente cedidos pelo Dr. Michel Nussenzweig (The Rockefeller University, Nova York).

Cada plasmídeo da cadeia pesada codifica para a porção variável do anticorpo de interesse (anti-DEC205 ou 33D1) seguida da porção constante da IgG1 de camundongo e de uma sequência "linker" (ASDMAKKETVWRLEEFGRF, Hawiger et al., 2001 e Dudziak et al., 2007). Todas as sequências dos genes de interesse foram clonadas em fase com estas sequências.

\subsection{Amplificação das sequências de DNA da proteína NS1 por PCR.}

O plasmídeo contendo o gene $n s 1$ de DENV2 foi gentilmente cedido pela Dra. Ada Maria de Barcelos Alves (Fundação Oswaldo Cruz, Instituto Oswaldo Cruz, Rio de Janeiro). A NS1 de DENV2 foi amplificada utilizando-se o plasmídeo pcENS1 (Costa et al., 2007) como molde.

Para a amplificação do gene $n s 1$ de DENV2, desenhamos o seguinte par de oligonucleotídeos:

NS1-Forward:

5'- GCTCGAGGAGTTCGGTAGGTTCGATAGTGGTTGCGTTGTGAG-3'

NS1-Reverse:

\section{5'- GGCGGCCGCTCAGGCTGTGACCAAGGAGTTG -3'}

Os sítios sublinhados correspondem às sequências das enzimas Xho I e Not I, respectivamente. 
Os oligonucleotídeos foram obtidos da Invitrogen na escala de síntese de $25 \mathrm{nM}$ e diluídos em estoques de $50 \mu \mathrm{M}$ em água MilliQ.

As reações de PCR foram feitas utilizando-se a enzima "Pfu DNA Polymerase" (Stratagene), seguindo-se as instruções do fabricante. Brevemente, para cada 40 ng de DNA molde adicionou-se tampão Pfu $1 \mathrm{X}, 0,2 \mathrm{mM}$ de dNTP, 0,4 $\mu \mathrm{M}$ de cada oligonucleotídeo iniciador e 1,25 U da enzima Pfu DNA Polymerase. As reações de amplificação foram feitas da seguinte maneira: 1 ciclo de $94{ }^{\circ} \mathrm{C}$ por 5 minutos, seguido de 30 ciclos de $94{ }^{\circ} \mathrm{C}$ por 30 segundos, $55^{\circ} \mathrm{C}$ por 30 segundos e $72{ }^{\circ} \mathrm{C}$ por $1-2$ minutos (dependendo do tamanho do gene a ser amplificado). O ciclo de extensão foi feito a $72{ }^{\circ} \mathrm{C}$ por 10 minutos. Acrescentou-se então 1 $\mathrm{U}$ da enzima Taq DNA polimerase e as reações foram incubadas por mais 15 minutos a $72{ }^{\circ} \mathrm{C}$. As amostras foram misturadas com tampão de amostra e analisadas imediatamente em géis de agarose $1 \%$.

\subsection{Clonagem do gene ns1 de DENV2 em fusão com os plasmídeos codificando as cadeias pesadas dos anticorpos anti-DEC205 e 33D1.}

Os produtos de PCR amplificados com descrito no item anterior foram clonados no vetor pCR2.1 utilizando-se o "TA cloning kit" (Invitrogen), de acordo com as instruções do fabricante. Os produtos da ligação foram então transformados em bactérias DH5a e plaqueados em placas de LB sólido contendo $100 \mu \mathrm{g} / \mathrm{mL}$ de ampicilina (LB/AMP). Além de ampicilina, cada placa foi também tratada com $40 \mu \mathrm{L}$ de X-gal $(40 \mathrm{mg} / \mathrm{mL}$, Sigma) e $40 \mu \mathrm{L}$ de IPTG (100mM, Amresco). Este tratamento permitiu que as colônias fossem separadas em brancas (contendo inserto) e azuis (sem inserto). Cinco colônias brancas foram então crescidas meio LB/AMP por 16 horas a $37{ }^{\circ} \mathrm{C}$ e sob agitação constante ( 200 rpm). Os plasmídeos foram então extraídos por maxi-prep.

Cerca de 1-3 $\mu$ g dos plasmídeos pCR2.1 contendo o gene ns1 de DENV2 foram digeridos com $5 \mathrm{U}$ das combinações das enzimas de restrição Xho I/Not I (New England Biolabs) na presença de tampão adequado (1X), a $37{ }^{\circ} \mathrm{C}$ por 2-16 horas. Os fragmentos de DNA equivalentes aos tamanhos dos genes de interesse foram separados por eletroforese e purificados dos géis utilizando-se o "Qiaquick gel extraction kit” (QIAGEN).

Paralelamente, $2 \mu \mathrm{g}$ dos plasmídeos contendo as cadeias pesadas dos anticorpos $\alpha \mathrm{DEC}$ e 33D1 foram digeridos com $5 \mathrm{U}$ da combinação das enzimas de restrição Xho I e Not I na 
presença de tampão adequado $(1 \mathrm{X})$, a $37^{\circ} \mathrm{C}$ por 2-16 horas. A separação e purificação dos fragmentos de DNA foram feitas conforme descrito acima. Após a purificação, os DNAs foram dosados e as ligações foram realizadas utilizando-se $1 \mathrm{U}$ da enzima T4 DNA ligase (New England Biolabs) e 1X tampão de ligação contendo ATP em $10 \mu 1$ de reação. Considerou-se então uma proporção molar de 3:1 entre inserto: vetor e cerca de 50ng de vetor foram utilizados em cada ligação, seguindo a seguinte fórmula:

[tamanho do inserto (pb) X quantidade do vetor]/ tamanho do vetor $(\mathrm{pb})=$ quantidade do inserto (ng)

As ligações aconteceram a $14{ }^{\circ} \mathrm{C}$ pelo período de 16-18 horas e foram transformadas em bactérias DH5a. Cerca de quatro colônias obtidas de cada ligação foram crescidas, tiveram seus plasmídeos extraídos e digeridos com as enzimas Xho I/Not I, conforme descrito acima.

Os plasmídeos contendo insertos de tamanho correto foram sequenciados. Os plasmídeos contendo as sequências corretas foram designados: pDEC-NS1 e p33D1-NS1.

\subsection{Produção dos anticorpos quiméricos por transfecção transiente de células HEK293T e purificação dos mesmos à partir dos sobrenadantes das culturas.}

Foram utilizadas placas de 150mm (Costar ou TPP) posteriormente semeadas com 7,5×10 ${ }^{6}$ células HEK293T (gentilmente cedidas pelo Prof. Dr. Armando Morais Ventura, Universidade de São Paulo, Departamento de Microbiologia, São Paulo) em meio DMEM, acrescido de $2 \mathrm{mM}$ L-glutamina, 10U/mL antibiótico-antimicótico, $1 \mathrm{mM}$ piruvato de sódio e $5 \%$ de soro fetal bovino com baixa concentração de IgG (Invitrogen). Após dois dias em cultura (quando a confluência estava em torno de 70\%), o meio das placas foi substituído por meio DMEM contendo os aditivos acima, sendo o soro fetal bovino substituído por $1 \%$ de nutridoma (Roche). Em seguida, as células foram transfectadas utilizando-se $10 \mu \mathrm{g}$ de cada um dos plasmídeos que codificam para as cadeias leve e pesada dos anticorpos $\alpha \mathrm{DEC}$ e 33D1 em fusão com a proteína NS1 de DENV2 na presença de polietilenimina $(0,45 \mathrm{mg} / \mathrm{mL}$, Sigma). Brevemente, os $10 \mu \mathrm{g}$ de cada plasmídeo foram dissolvidos em $1 \mathrm{~mL}$ de uma solução de $150 \mathrm{mM}$ de $\mathrm{NaCl}$. Após curta agitação, $100 \mu \mathrm{L}$ de uma solução de polietilenimina 0,45 $\mathrm{mg} / \mathrm{mL}$ foram adicionados e a mistura foi submetida a agitação por 10 segundos, seguida de incubação por 10 minutos à temperatura ambiente. $\mathrm{O}$ volume final de $1,1 \mathrm{~mL}$ foi então 
adicionado a cada placa utilizado-se uma pipeta de 1mL. Após 5-7 dias em cultura, os sobrenadantes das culturas foram coletados, filtrados e então precipitados em uma solução contendo $60 \%$ de sulfato de amônio (Sigma). Os precipitados foram coletados por centrifugação e re-dissolvidos em PBS. Após uma diálise de 4 horas em PBS, os anticorpos quiméricos foram purificados utilizando-se "beads" de proteína G (Amersham-Pharmacia) de acordo com o protocolo descrito pelo fabricante.

\subsection{Avaliação da integridade dos anticorpos quiméricos e da proteína NS1 fusionada a} eles.

A integridade dos anticorpos foi analisada em gel de SDS-PAGE 12\% em condições redutoras (aquecimento a $95{ }^{\circ} \mathrm{C}$ por 5 minutos na presença de DTT) seguido de coloração por Coomassie Blue. A concentração dos anticorpos foi obtida utilizando-se uma curva padrão de IgG1 (BD biosciences) e o reagente de Bradford (Amresco). Os anticorpos quiméricos foram então aliquotados e estocados a $-20^{\circ} \mathrm{C}$ até uso.

Também avaliamos a integridade da proteína NS1 fusionada aos anticorpos através da detecção desta em ensaio de Western Blot. Brevemente, $1 \mu \mathrm{g}$ de cada um dos anticorpos $(\alpha \mathrm{DEC}-\mathrm{NS} 1$ e 33D1-NS1) ou de um anticorpo controle negativo $(\alpha \mathrm{DEC}-\Delta \mathrm{N}$, contendo a proteína circusmporozoíta de Plasmodium falciparum) foram aplicados em um gel de SDSPAGE $12 \%$ e submetidos a uma corrente elétrica fixa em uma cuba de eletroforese. O Gel foi então retirado, e montado sobre uma membrana de nitrocelulose em aparato específico para transferência. Aplicou-se uma corrente fixa de $100 \mathrm{~V}$ por $2 \mathrm{~h}$ para que as proteínas do gel migrassem para a membrana de nitrocelulose que foi então recuperada, avaliando-se a transferência por coloração com corante Ponceau S. A membrana foi então bloqueada por $12 \mathrm{~h}$ em PBS $+0.05 \%$ Tween $20+5 \%$ Leite Desnatado, e marcada utilizando-se um soro primário anti-NS1 na concentração de 1:2000 (Gentilmente cedido pelo Prof. Luis Carlos de Souza Ferreira, Universidade de São Paulo, Departamento de Microbiologia, São Paulo) ou anti-IgG 1:10000 (BD Bioscience). Após lavagem com PBS+Tween20 0.05\% utilizamos um anticorpo secundário anti-IgG2a para detectarmos o anticorpo primário sem detectarmos os anticorpos monoclonais (subclasse IgG1). Revelamos a membrana em filme fotográfico ou aparelho de quimioluminescência. 


\subsection{Ensaio para deteç̧ão de LPS.}

Para dosagem de LPS nas amostras contendo os anticorpos quiméricos, utilizou-se o kit QCL-1000 (Lonza). Brevemente, $5 \mu \mathrm{g}$ de cada anticorpo quimérico foram diluídos em um volume final de $50 \mu \mathrm{L}$ de água livre de pirógeno. Em seguida, cada amostra foi incubada a $37{ }^{\circ} \mathrm{C}$. Após estabilização da temperatura, foram adicionados $50 \mu \mathrm{L}$ de lisado de amebócitos de limulus. Após incubação a $37{ }^{\circ} \mathrm{C}$ por 10 minutos, foram adicionados $100 \mu \mathrm{L}$ de uma solução cromógena, seguindo incubação por mais 6 minutos. A reação foi parada adicionando-se $50 \mu \mathrm{L}$ de ácido acético a $25 \%$. As amostras foram lidas em espectrofotômetro com $\mathrm{DO}_{405 \mathrm{~nm}}$. Uma curva contendo concentrações conhecidas de LPS (1, 0.5, 0.25 e 0.125 $\mathrm{EU} / \mathrm{mL}$ ) foi diluída juntamente com as amostras.

\subsection{Ensaio de ligação dos anticorpos híbridos a DCs presentes no baço de camundongos.}

Os anticorpos híbridos purificados foram testados nas seguintes concentrações: 10, 1, $0,1 \mu \mathrm{g} / \mathrm{mL}$. Estes anticorpos foram então incubados com $5 \times 10^{6}$ esplenócitos obtidos após lise das hemácias com tampão ACK (EDTA 0,1mM, $\mathrm{NH}_{4} \mathrm{Cl}$ 0,15 mM, $\mathrm{KHCO}_{3} 1 \mathrm{mM}$ ) e ressuspendidos em tampão de FACS (PBS+2\% soro fetal bovino) contendo o anticorpo Fc block (anti-CD16/32, BD Pharmingen) na diluição de 1:100. Após 15 minutos de incubação em gelo, os anticorpos híbridos nas concentrações finais citadas acima foram adicionados. Após mais 45 minutos de incubação, as células foram centrifugadas e lavadas 2 vezes com tampão de FACS. Seguiu-se então uma incubação de 45 minutos com os anticorpos (todos da BD Pharmingen): anti-IgG1-PE, anti-MHC II-FITC, anti-CD8-PECy7, anti-CD11c-APC, anti-DX5 biotinilado e anti-CD19 biotinilado. Após mais 2 lavagens, as células foram incubadas com estreptavidina-PerCP por mais 30 minutos. Finalmente, após 2 lavagens, as amostras foram então lidas em citômetro de fluxo (FACS Canto) e analisadas utilizando-se o software FlowJo (TreeStar).

\subsection{Clonagem, expressão e purificação da proteína recombinante NS1 produzida em bactérias.}

A fase de leitura aberta da proteína NS1 foi subclonada no vetor pET28b, sob o controle de um operon lac, para fusão com uma cauda de histidinas. A purificação das 
proteínas em fusão com as caudas de histidina foi realizada utilizando colunas de níquel (NiNTA Fast Flow, Qiagen) e os protocolos descritos no manual QIAExpressionist da Quiagen. Brevemente, bactérias BL21DE3 foram transformadas e selecionadas por crescimento em placa de meio LB-Ágar + Ampicilina $100 \mu \mathrm{g} / \mathrm{mL}$, através da presença de um gene de resistência ao antibiótico Ampicilina existente no vetor pET28b. Uma colônia que apresentava o vetor com o inserto do gene $n s l$ foi selecionada e cultivada em $500 \mathrm{~mL}$ de meio $\mathrm{LB}($ Amresco $)+$ Ampicilina a $37^{\circ} \mathrm{C}$ e sob agitação constante até atingir $\mathrm{OD}_{600}$ entre 0,6 e 0,8. Então, adicionou-se $0,01 \mathrm{mM}$ de IPTG (uma molécula análoga ao repressor do operon lac que compete pelo sítio do repressor, e permite a expressão das moléculas sob controle deste operon), e incubamos a cultura a $37{ }^{\circ} \mathrm{C}$ por $4 \mathrm{~h}$ sob agitação constante. As bactérias foram coletadas por centrifugação e ressuspendidas em tampão de sonicação $(100 \mathrm{mM}$ Tris- $\mathrm{HCl}$ e $500 \mathrm{mM} \mathrm{NaCl}-\mathrm{pH} 8.0$ ). A lise ocorreu no gelo com o auxílio de um sonicador (Branson Sonifier Ultrasonic Processor 450, USES). Três ciclos de sonicação foram aplicados consistindo de pulsos de 5 minutos com 5 minutos de intervalo na potência 45 . O lisado bacteriano foi centrifugado a $18.000 \mathrm{X}$ g por 30 minutos a $4{ }^{\circ} \mathrm{C}$.

Após a centrifugação, a fração insolúvel de corpúsculos de inclusão foi ressuspendida em Tampão de Desnaturação (100 mM Tris-HCl, $500 \mathrm{mM} \mathrm{NaCl}$ e $8 \mathrm{M}$ Uréia - pH 8,0) e mantido sobre agitação leve a $4{ }^{\circ} \mathrm{C}$ por $12-18 \mathrm{~h}$. O extrato obtido foi centrifugado a $18.000 \mathrm{x} \mathrm{g}$ por $45 \mathrm{~min}$ e filtrado. O sobrenadante foi incubado sob agitação com uma resina de $\mathrm{Ni}^{2+}$-NTAAgarose (QIAGEN) e aplicado a uma coluna montada para eluição da proteína por cromatografia de afinidade a Níquel, que foi então lavada exaustivamente com Tampão de Desnaturação. A proteína foi eluída com a utilização de um Tampão de Eluição (100 mM Tris- $\mathrm{HCl}, 500 \mathrm{mM} \mathrm{NaCl}$ e $8 \mathrm{M}$ Uréia - pH 4,0). As amostras foram testadas por coloração com Reagente de Bradford (Amresco) e as amostras positivas para a presença de proteína foram separadas e testadas em gel de SDS-PAGE 12\% para confirmar sua pureza.

Por fim, para realizar o refolding da proteína desnaturada, as amostras foram agrupadas e dialisadas contra um gradiente de tampão que variou lentamente $(0.25 \mathrm{~mL} / \mathrm{min})$ por $18 \mathrm{~h}$ do Tampão de Eluição ao Tampão Final $(100 \mathrm{mM}$ Tris-HCl, $500 \mathrm{mM} \mathrm{NaCl}, 2 \mathrm{M}$ Uréia e 10\% Glicerol - pH8.0). 


\subsection{Imunização de camundongos com os diferentes anticorpos quiméricos na presença de diferentes estímulos de ativação para as DCs e análise da resposta imune celular gerada pelas diferentes combinações.}

Para os estudos envolvendo a proteína NS1 do vírus da dengue, o delineamento experimental foi o seguinte: grupos de 5 camundongos $\mathrm{BALB} / \mathrm{c}$ foram imunizados (intraperitonealmente) nas seguintes condições:

Camundongos fêmeas BALB/c receberam uma dose única dos anticorpos quiméricos na presença de diferentes estímulos de maturação para DCs. Utilizamos $50 \mu \mathrm{g}$ de cada anticorpo quimérico na presença das seguintes concentrações de adjuvantes:

$\mathrm{CpG}-25 \mu \mathrm{g} / \mathrm{animal}$

Poly I:C $-50 \mu \mathrm{g} /$ animal

MDP - $100 \mu \mathrm{g} / \mathrm{animal}$

As condições específicas de cada experimento serão descritas na seção de Resultados.

Sangrias foram realizadas nos animais 7 dias após a imunização. Para os experimentos envolvendo cultura celular os animais foram sacrificados 2 semanas após a imunização, exceto quando especificado diferentemente.

\subsection{Ensaio ELISPOT para análise do número de células produtoras de IFN- $\gamma$.}

Para o ensaio de ELISPOT, utilizou-se o kit "Ready-SET-Go!” (eBioscience) para detecção de INF- $\gamma$ e placas de nitrocelulose com 96 poços (MAIPS 4510, Millipore). As placas foram cobertas com $100 \mu \mathrm{L}$ / poço de tampão estéril contendo o anticorpo monoclonal anti-INF- $\gamma$ de captura diluído $250 x$. Após incubação em período noturno a $4{ }^{\circ} \mathrm{C}$, a solução contendo o anticorpo monoclonal foi removida em ambiente estéril e as placas foram então lavadas 3 vezes com tampão estéril. As placas foram bloqueadas pela incubação dos poços com $200 \mu \mathrm{L}$ de meio RPMI (GIBCO) contendo 10\% de soro fetal bovino (Invitrogen) por, pelo menos, 2 horas a $37^{\circ} \mathrm{C}$.

As células respondedoras foram obtidas dos baços de 2-3 camundongos imunizados com os diferentes anticorpos híbridos ou controles. As hemácias foram lisadas na presença do tampão ACK (EDTA 0,1mM, $\mathrm{NH}_{4} \mathrm{Cl} 0,15 \mathrm{mM}, \mathrm{KHCO}_{3} 1 \mathrm{mM}$ ). As células foram então lavadas 3 vezes com meio RPMI, ressuspendidas em meio RPMI completo contendo $10 \%$ de soro fetal bovino (R10) e $30 \mathrm{U}$ de IL-2 humana recombinante e diluídas para uma concentração de 1 a $1,5 \times 10^{6}$ células $/ \mathrm{mL}$. 
Cada suspensão contendo $100 \mu \mathrm{L}$ de células respondedoras foi pipetada individualmente em cada poço, seguida de mais $100 \mu \mathrm{L}$ do antígeno diluído na concentração desejada. As placas foram incubadas em condições estáticas por $18-20$ horas a $37{ }^{\circ} \mathrm{C}$ em atmosfera contendo $5 \%$ de $\mathrm{CO}_{2}$. Depois da incubação, as células foram desprezadas. Para remover quaisquer células residuais, as placas foram lavadas por 3 vezes com PBS-Tween20 0,05\% (PBS-T0,05). Cada poço recebeu então $100 \mu \mathrm{L}$ do anticorpo monoclonal anticamundongo biotinilado diluído 250x em tampão "assay buffer 1x" contido no kit. As placas foram incubadas por 2 horas a temperatura ambiente. Os anticorpos não ligados foram removidos pela lavagem das placas por 3 vezes com PBS-T0,05. Adicionou-se então estreptavidina-peroxidase diluída 250x em "assay buffer $1 \mathrm{x}$ ” em volume final de $100 \mu \mathrm{L} /$ poço. As placas foram incubadas por 1 hora à temperatura ambiente e então lavadas 3 vezes com PBS-T0,05 e mais 2 vezes com PBS. As placas foram reveladas adicionando-se $100 \mu \mathrm{L} /$ poço do substrato cromogênico contido no kit AEC (Becton Dickinson) seguindo por mais 45 minutos de incubação a $37^{\circ} \mathrm{C}$. A reação foi interrompida descartando-se a solução substrato e lavando-se as placas com água corrente. As placas foram então secas à temperatura ambiente e os "spots" foram contados em contador automatizado (AID GmbH).

\subsection{Análise da sobrevivência dos animais imunizados após desafio utilizando o vírus NGC DENV2.}

O desafio dos animais foi feito pelo grupo da Dra. Ada Maria de Barcelos Alves (Fundação Oswaldo Cruz, Instituto Oswaldo Cruz, Rio de Janeiro) que cresce e mantém o vírus NGC DENV2.

Diferentes grupos de 8 camundongos BALB/c machos foram imunizados intraperitonealmente com 2 doses $(5 \mu \mathrm{g} /$ animal) dos diferentes anticorpos quiméricos e $50 \mu \mathrm{g}$ de Poly I:C, ou somente com Poly I:C ou veículo. Quinze dias após a segunda dose, os animais foram desafiados de acordo com o seguinte protocolo:

Os animais foram anestesiados com uma mistura de quetamina-xilazina e então inoculou-se, através da via intracerebral (i.c.), $3 \mu \mathrm{L}$ de NGC DENV2, que correspondem aproximadamente à $\mathrm{LD}_{50}$. Os camundongos foram então monitorados por 21 dias após o desafio, avaliando-se a mortalidade e a morbidade, expressa principalmente pelo aparecimento de paralisia das patas traseiras e alterações na coluna. A avaliação da morbidade foi realizada utilizando-se uma escala de 0 a $3(0=$ sem alterações; $1=$ paralisia leve de uma pata traseira ou alteração da coluna com uma corcunda pequena; 2 = paralisia severa de uma 
das patas traseiras e alteração da coluna com uma corcunda pequena ou paralisia severa em ambas patas traseiras; 3 = paralisia severa em ambas patas traseiras e coluna deformada ou morte). Após 21 dias, os animais que sobreviveram ao desafio foram sacrificados.

Em um dos experimentos de desafio, grupos de animais imunizados com o anticorpo $\alpha$ DEC-NS1+Poly I:C foram depletados de células T $\mathrm{CD} 4^{+}$ou $\mathrm{CD}^{+}$um dia antes do desafio com o vírus DENV2 utilizando $100 \mu \mathrm{g}$ dos clones GK1.5 (anti-CD4) e 53-6.7 (anti-CD8).

\subsection{Ensaio de ELISA.}

O ensaio de ELISA para a detecção dos anticorpos presentes no soro dos animais imunizados foi realizado da seguinte maneira:

Foram utilizadas placas de ELISA ("High binding", Costar). A cada poço foram adicionados 200ng da proteína NS1 ou 100ng da proteína MSP-1 ${ }_{19}$ de $P$. vivax diluída em PBS 1X. As placas foram então deixadas à temperatura ambiente por 16-18 horas e posteriormente lavadas três vezes com a solução de PBS-Tween20 (Synth) 0,02\%.

Cada poço foi então bloqueado com $150 \mu \mathrm{L}$ de uma solução de bloqueio (PBS-T0,02+ $5 \%$ leite desnatado $+1 \%$ BSA, AMRESCO) durante 1 hora a temperatura ambiente. Em seguida, as placas foram incubadas por 2 horas com $100 \mu \mathrm{L}$ dos soros (diluídos em PBST0,2+ leite 5\%+ BSA 0,25\%) em diluições seriadas (fator de diluição 3). As placas foram então lavadas por 3 vezes com PBS-T0,02 e o anticorpo secundário contendo anti-IgG de camundongo ligada a peroxidase (Jackson Laboratories) diluído em PBS-T0,02+ leite 5\%+ BSA $0,25 \%$ na proporção de 1:10.000 foi adicionado e incubado por mais 2 horas à temperatura ambiente $(50 \mu \mathrm{L} /$ poço). Após três lavagens com PBS-T0,02, cada poço recebeu $100 \mu \mathrm{L}$ do substrato preparado da seguinte maneira: $10 \mathrm{mg}$ de OPD (Sigma) dissolvidos em $10 \mathrm{~mL}$ de uma solução contendo fosfato de sódio (Synth) 0,2M e ácido cítrico (Synth) 0,1M (pH 4,7) acrescido de $10 \mu \mathrm{L}$ de $\mathrm{H}_{2} \mathrm{O}_{2} 30 \%$. Depois de 15 minutos, a reação foi interrompida com $50 \mu \mathrm{L}$ de uma solução de $\mathrm{H}_{2} \mathrm{SO}_{4}$ (Synth) $4 \mathrm{~N}$. As placas foram lidas em leitor BioTek ELx800 (Biotek) em comprimento de onda de $595 \mathrm{~nm}$. Considerou-se como valor de título o primeiro valor de diluição em que a $\mathrm{DO}_{595} \mathrm{~nm}$ observada fosse superior a 0,1 . Os gráficos foram construídos utilizando-se o valor do $\log$ da diluição correspondente ao título encontrado. 


\subsection{Ensaio de marcação intracelular para deteç̧ão das citocinas inflamatórias IFN- $\gamma$, IL-2 e TNF- $\alpha$.}

Esplenócitos isolados dos camundongos injetados com os anticorpos quiméricos ou controles foram plaqueados em uma concentração de $1 \times 10^{6}$ células/poço e incubados com os antígenos específicos, em meio R10 contendo $2 \mu \mathrm{g} / \mathrm{mL}$ do anticorpo $\alpha \mathrm{CD} 28$. Alguns poços foram incubados com $1 \mu \mathrm{g} / \mathrm{mL}$ de $\alpha \mathrm{CD} 3$ como controle positivo. Após uma hora de incubação, cada poço recebeu 0,5 $\mu \mathrm{L}$ de Golgi Plug (Brefeldina A, BD Pharmingen) e as placas foram incubadas por mais 12-16 horas. Após este período, as placas foram centrifugadas por 5 minutos a $1.000 x$ e os sobrenadantes foram descartados por inversão. Acrescentou-se $150 \mu \mathrm{L}$ de tampão de FACS e as triplicatas foram combinadas em um único poço. Seguiu-se incubação com os seguintes anticorpos para marcação extracelular: antiCD4-PerCP-Cy5.5 e anti-CD8-PE-Cy7 por 45 minutos em tampão FACS no gelo. Após esse período, as células foram lavadas 3 vezes com tampão FACS e ressuspendidas em $200 \mu \mathrm{L}$ de PharmingenStain buffer (BD Pharmingen) seguida por mais uma centrifugação, posteriormente adicionando-se $100 \mu \mathrm{L}$ /poço de Cytofix/Cytoperm (BD Pharmingen). As células foram ressuspendidas e incubadas por 15 minutos no gelo. Após esse período, as placas foram centrifugadas e lavadas por 3 vezes com tampão Permwash (BD Pharmingen). As células foram então incubadas com os seguintes anticorpos para marcação intracelular: anti-CD3-APC-Cy7, anti-IL2-FITC, anti-TNF $\alpha$-PE e anti-INF $\gamma$-APC por 45 minutos no gelo. Após mais 3 lavagens com tampão Permwash, as células foram ressuspendidas em tampão de FACS e lidas no citômetro FACS Canto (BD). Todos os anticorpos utilizados foram adquiridos da BD Pharmingen.

\subsection{Ensaio de proliferação por diluição do corante CFSE.}

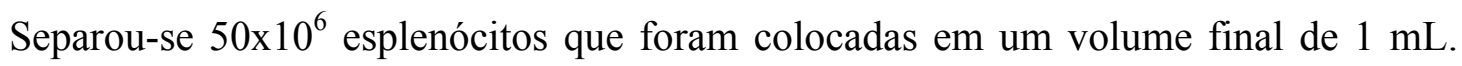
Após centrifugação, as células foram ressuspendidas em PBS previamente aquecido a $37{ }^{\circ} \mathrm{C}$ contendo o corante CFDA na concentração de final de 1,25 $\mu \mathrm{M}$ (Vybrant CFDA SE - Cell Tracer Kit, Molecular Probes). As células foram então incubadas a $37^{\circ} \mathrm{C}$ por 10 minutos em banho-maria e agitadas a cada 2 minutos para se obter uma marcação homogênea. Após esse período, as células foram centrifugadas a 1.000xg por 5 minutos e lavadas por 3 vezes com o 
dobro do volume usado na marcação. Finalmente, as células foram ressuspendidas em $1 \mathrm{~mL}$ de R10 e contadas novamente. Cada poço recebeu $3 \times 10^{5}$ células. As placas foram então incubadas a $37{ }^{\circ} \mathrm{C}, 5 \%$ de $\mathrm{CO}_{2}$ por 5 dias. Após este período, as placas foram centrifugadas, lavadas em tampão FACS e as triplicatas foram combinadas em um único poço. A marcação fenotípica foi feita com os seguintes anticorpos: anti-CD4-PerCP-Cy5.5, anti-CD8-PE-Cy7 e anti-CD3-APC-Cy7 por 45 minutos em tampão FACS e no gelo. As placas foram lavadas por 3 vezes com tampão FACS e as amostras lidas no citômetro FACS Canto.

\subsection{Análise dos resultados}

Análises estatísticas de significância foram realizadas através do teste ANOVA seguido de Tukey para comparação entre os diferentes grupos experimentais. Todos os testes foram realizados utilizando-se o programa GraphPad Prism 5, e diferenças foram consideradas significativas quando $\mathrm{p}<0,05$. 
4. RESULTADOS 


\subsection{Amplificação e clonagem do gene ns1 de DENV2 em fusão com os genes codificando para as cadeias pesadas dos anticorpos $\alpha$ DEC205 e 33D1.}

Os plasmídeos contendo as cadeias pesadas dos anticorpos anti-DEC e 33D1 foram gentilmente cedidos pelo Dr. Michel Nussenzweig (The Rockefeller University, Nova York). As sequências de nucleotídeos correspondentes às porções variáveis de cada um dos anticorpos foram clonadas à partir dos hibridomas originais (Hawiger et al., 2001; Dudziak et $a l .$, 2007) que foram gerados em rato. A porção variável de cada um dos anticorpos foi clonada em fusão com uma sequência de IgG1 de camundongo mutada no sítio reconhecido pelo receptor de Fc para tentar minimizar a geração de resposta imune contra o próprio anticorpo e evitar o direcionamento inespecífico dos anticorpos para células que expressam receptores Fc. Desta forma, as porções constantes são muito parecidas em todos os anticorpos enquanto que são as porções variáveis que diferem mais significativamente, pois são elas que apresentam especificidades de ligação diferentes (FIGURA 1).

FIGURA 1 - Alinhamento múltiplo, pelo método clustal W, das sequências de aminoácidos das cadeias pesadas dos anticorpos $\alpha$ DEC e 33D1.

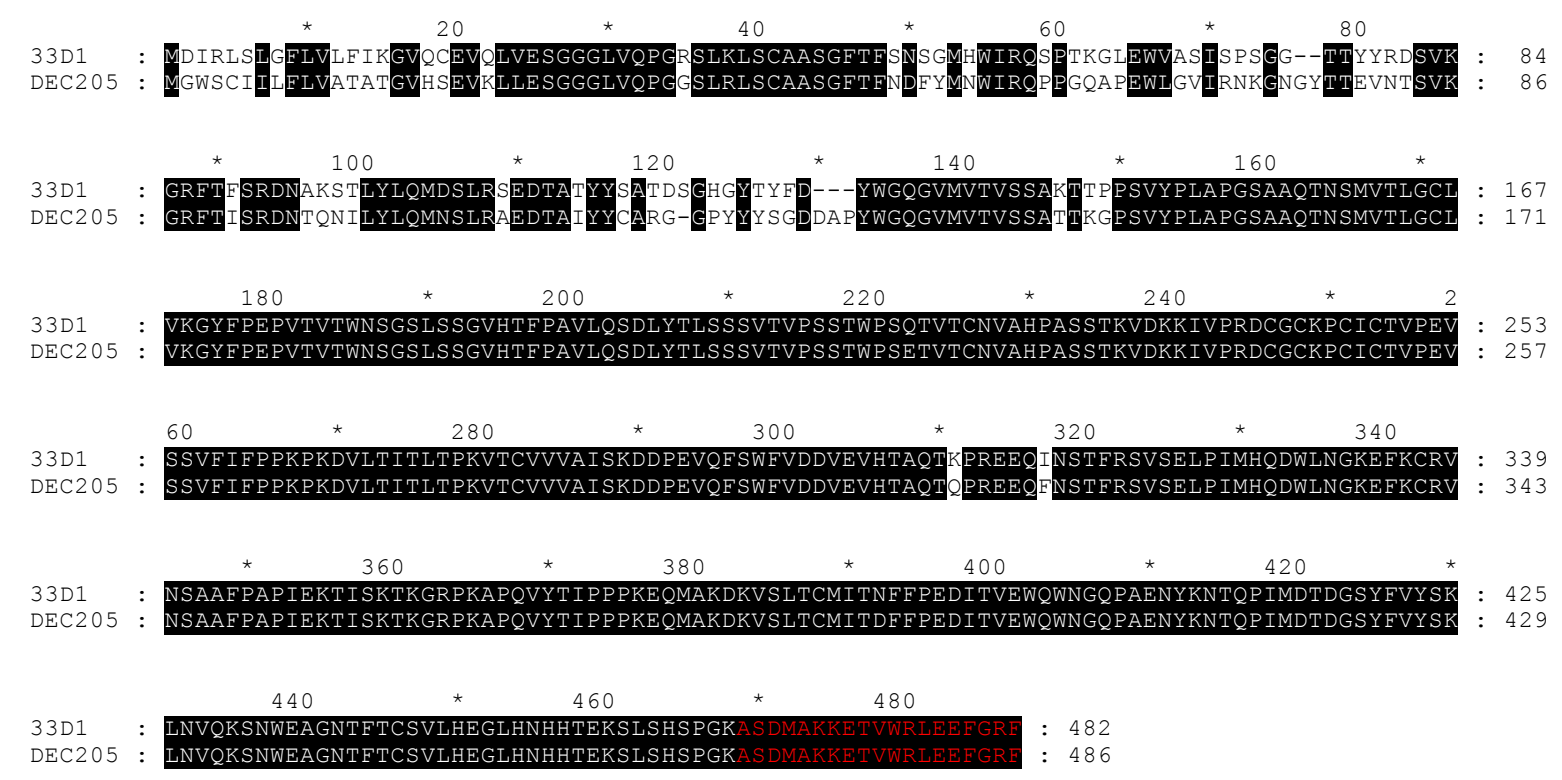

As caixas pretas indicam $100 \%$ de identidade entre as sequências e os aminoácidos marcados em vermelho representam a sequência do "linker".

Fonte: Rezende (2012)

O fragmento correspondente a NS1 de DENV2 foi amplificado por PCR utilizando-se a enzima de alta fidelidade Pfu. Após clonagem no plasmídeo pCR2.1, dois clones foram enviados para sequenciamento e não detectamos nenhuma mutação (dados não mostrados). 
Os mesmos foram também digeridos com as enzimas Xho I e Not I e os insertos clonados em fase nos vetores pDEC e p33D1 (FIGURA 2).

FIGURA 2 - Amplificação e clonagem do gene ns1 do vírus DENV2.
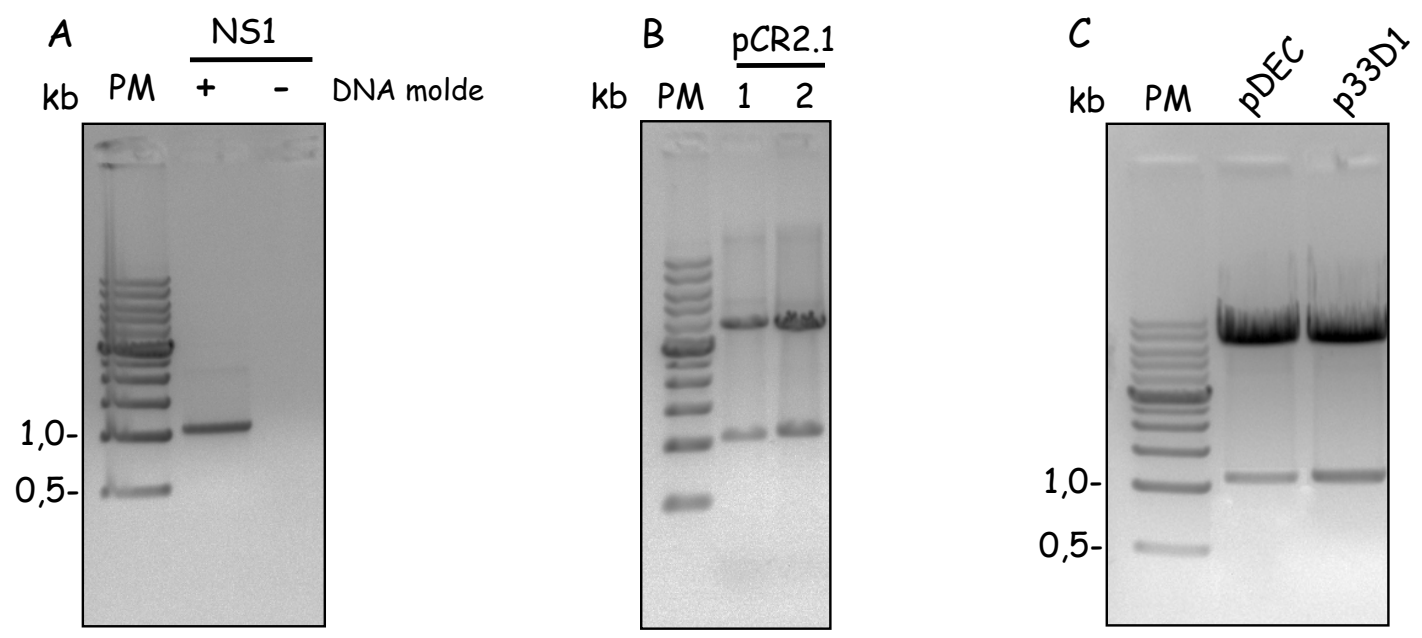

(A) A reação de PCR foi realizada na presença (+) ou ausência (-) do plasmídeo contendo o DNA molde utilizando os pares de oligonucleotídeos baseados na sequência do gene $n s 1$ do vírus DENV-2. (B) Os produtos de PCR foram clonados no vetor pCR2.1 e o DNA de 2 clones derivados de cada ligação foi posteriormente digerido com as enzimas Xho I e Not I. Os fragmentos liberados foram então subclonados nos vetores pDEC e p33D1. (C) Digestão dos plasmídeos pDEC e p33D1 com as enzimas Nhe $\mathrm{I} /$ Not $\mathrm{I}$. Os fragmentos foram separados em géis de agarose $1 \%$ e as bandas de 0,5 e $1,0 \mathrm{~kb}$ do padrão de peso molecular estão indicadas. $\mathrm{O}$ tamanho do fragmento esperado na reação de PCR era de 1056pb.

Fonte: Rezende (2012)

\subsection{Transfecção de células HEK293T e purificação dos anticorpos quiméricos associados} a NS1.

Inicialmente, transfectamos células HEK293T com as cadeias leve e pesada dos anticorpos $\alpha \mathrm{DEC}$ ou 33D1 em fusão com a proteína NS1 de DENV2. Após sua purificação, cada um dos anticorpos foi dosado pelo ensaio de Bradford e, confirmadas as concentrações por gel de SDS-PAGE, testado para contaminação com LPS (kit QCL-1000, Lonza). Nenhum dos anticorpos apresentou contaminação por LPS detectável no ensaio (dados não mostrados). Os géis de SDS-PAGE 12\% em condições redutoras mostraram as cadeias leve (de massa molecular em torno de $25 \mathrm{kDa}$ ) e pesada (aproximadamente $95 \mathrm{kDa}$ ) dos anticorpos $\alpha \mathrm{DEC}$ e 33D1 fundidos a NS1 (FIGURA 3A).

Também foram preparados géis de SDS-PAGE 12\%, em condições não redutoras, mantendo-se as cadeias do anticorpo, e consequentemente a proteína NS1 em sua conformação dimérica. Estes géis foram utilizados para Western Blot. A membrana foi então bloqueada e em seguida procedeu-se à marcação por primário anti-NS1 e por secundário anti- 
IgG2b (FIGURA 3B) ou, após stripping da membrana, marcação por primário anti-IgG total e por secundário anti-IgG2b (FIGURA 3B). Desta forma pudemos verificar a presença da proteína NS1 nos anticorpos, bem como a integridade destes.

FIGURA 3 - Normalização das concentrações de anticorpos quiméricos $\alpha$ DEC-NS1 e 33D1-NS1.

A)

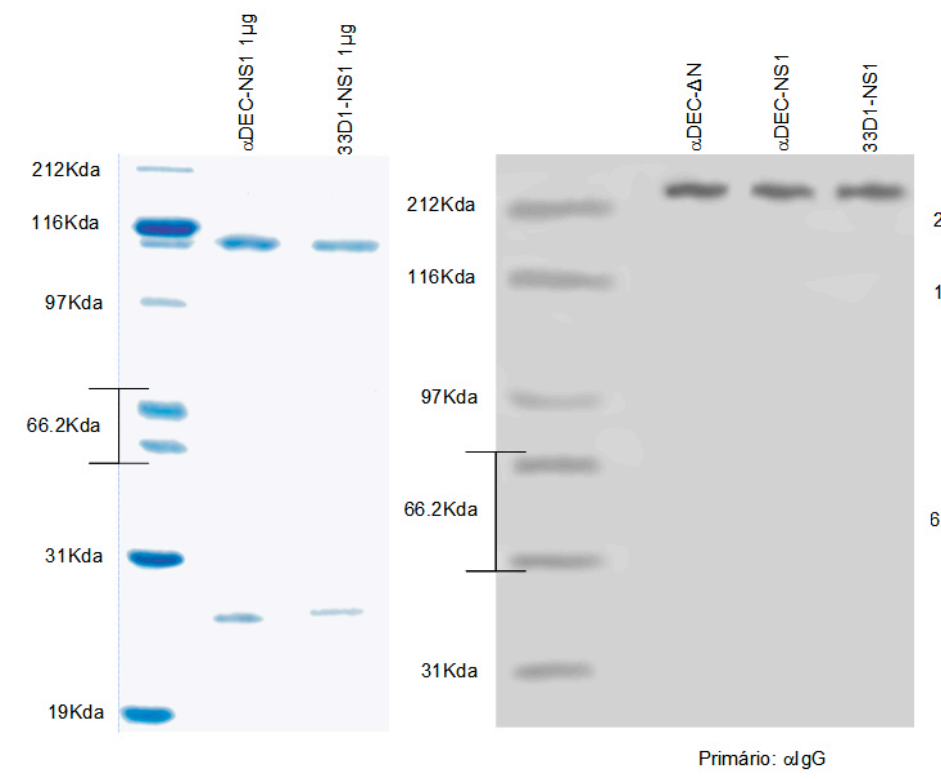

B)

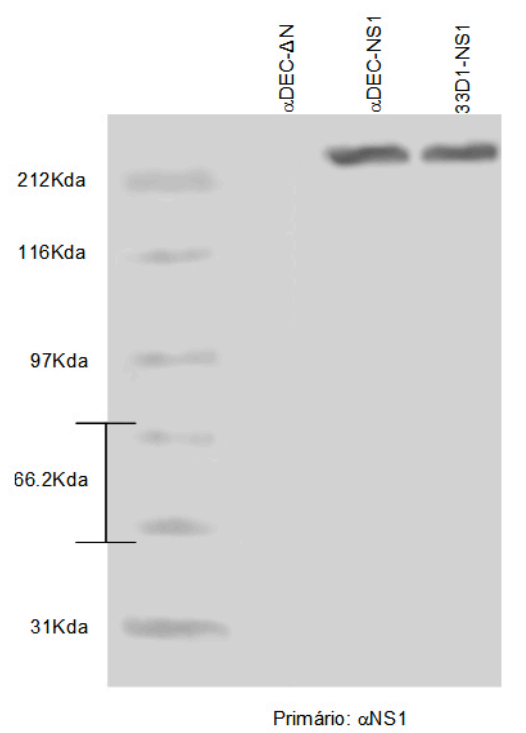

(A) Os anticorpos foram desnaturados em condições redutoras e correu-se um gel SDS-PAGE 12\%. Para cada anticorpo podemos observar a banda referente a cadeia pesada ligada a NS1, com PM de 95kDa, e a banda referente a cadeia leve, com PM de $25 \mathrm{kDa}$. As bandas do peso molecular referentes a 116 , 97 e $31 \mathrm{kDa}$ estão indicadas. (B) Western blot confirmando a presença da proteína NS1 nos anticorpos quiméricos.

Fonte: Rezende (2012)

\subsection{Ensaio de ligação dos anticorpos quiméricos contendo a proteína NS1 em DCs provenientes do baço de camundongos.}

Após verificarmos a integridade dos anticorpos produzidos e da conformação da proteína NS1 fusionada a eles, resolvemos verificar se a cada anticorpo mantinha a especificidade de ligação aos seus receptores específicos DEC205 e DCIR2. Para isso, através de citometria de fluxo, utilizamos uma estratégia de gating baseada, primeiramente, na exclusão de linfócitos $\mathrm{B}\left(\mathrm{CD} 19^{+}\right)$e Células $\mathrm{NK}\left(\mathrm{DX} 5^{+}\right)$, pois estas poderiam apresentar também MHCII. Em seguida, selecionamos a população de células $\mathrm{MHCII}^{+}$, onde esperamos encontrar as DCs. Por fim, selecionamos as células positivas para CD11c (marcador de cDCs), separando estas células, de acordo com a expressão da cadeia alfa da molécula CD8 em duas populações, sendo o grupo de células $\mathrm{CD}^{+}$, considerado como as DCs 
$\mathrm{CD}^{+}{ }^{+} \mathrm{DEC} 205^{+}$e o grupo de células $\mathrm{CD}^{-}$como as $\mathrm{DCs} \mathrm{CD8}^{-} \mathrm{DCIR} 2^{+}$(para a definição desta populações ver Dudziak et al., 2007). Observamos, neste experimento, a ligação específica do anticorpo quimérico $\alpha \mathrm{DEC}-\mathrm{NS} 1$ à população de células $\mathrm{CD} 8^{+} \mathrm{DEC} 205^{+}$e do anticorpo 33D1NS1 à população CD8-DCIR2 ${ }^{+}$(FIGURA 4).

FIGURA 4 - Ligação dos anticorpos quiméricos a populações de células dendríticas presentes no baço de camundongos $B A L B / c$.
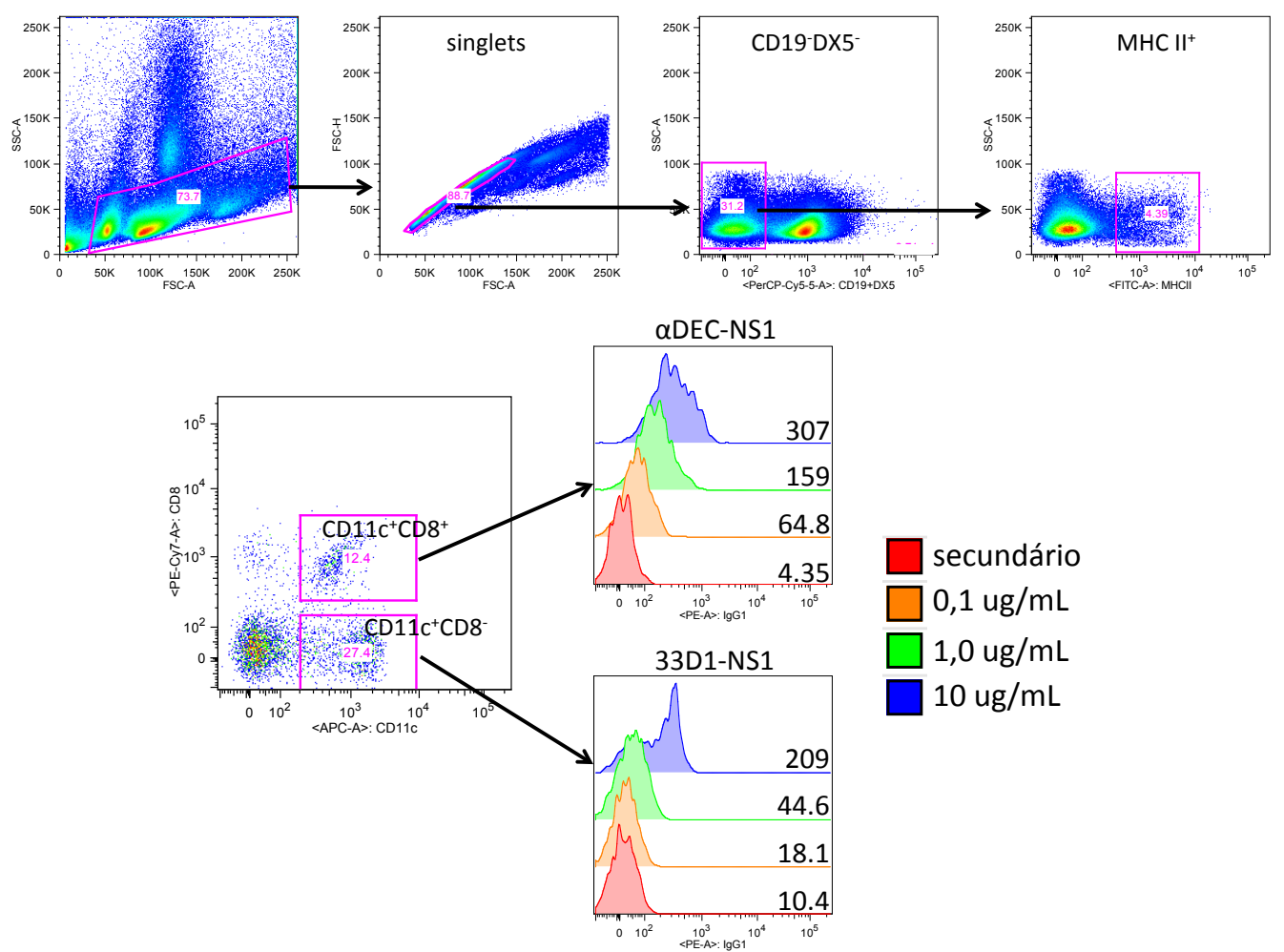

Esplenócitos foram purificados e incubados com 10, 1 e $0,1 \mathrm{ug} / \mathrm{mL}$ dos anticorpos $\alpha$ DEC-NS1 e 33D1-NS. Após incubação, os esplenócitos foram marcados com anticorpos anti-CD19, anti-MHCII, anti-DX5, anti-CD11c e anti-CD8. Através da estratégia de gating mostrada acima, selecionamos as células CD19-DX5 MHCII ${ }^{-} \mathrm{CD} 11 \mathrm{c}^{+}$, que consideramos como DCs clássicas, e subdividimos estas em duas populações, de acordo com a expressão da cadeia alfa da molécula CD8. A ligação das diferentes concentrações dos anticorpos às populações de DCs de interesse está mostrada nos histogramas utilizando-se um anticorpo anti-IgG1 de camundongo como secundário. Os números expressos na frente de cada histograma indicam as medianas de fluorescência (MFI).

Fonte: Rezende (2012)

\subsection{Produção da proteína NS1 recombinante.}

O fragmento correspondente a NS1 de DENV2 foi amplificado por PCR utilizando-se a enzima de alta fidelidade Pfu. Após clonagem no plasmídeo pCR2.1, dois clones foram enviados para sequenciamento e não detectamos nenhuma mutação (dados não mostrados). Os mesmos foram também digeridos com as enzimas Xho I e Not I e os insertos clonados em 
fase no vetor pET28b. O segundo foi transformado em bactérias E. coli da cepa BL21/DE3 competentes e a expressão do plasmídeo foi induzida utilizando-se $0,1 \mathrm{mM}$ de IPTG.

A proteína, após sonicação, foi extraída em coluna de Níquel, mas apresentou precipitação ao ser dialisada contra PBS puro. Procedemos a sua solubilização em PBS+Uréia $8 \mathrm{M}$, que foi em seguida lentamente diluída até chegarmos a uma solução de PBS+2M Uréia $+10 \%$ Glicerol que foi capaz de manter a proteína estável e solúvel. Para confirmarmos a purificação da proteína NS1, comparamos a corrida em gel de SDS-PAGE 12\% de nossa proteína e de uma proteína recombinante testada previamente, gentilmente cedida pelo Prof. Luis Carlos de Souza Ferreira, que comprovou a integridade da proteína produzida (FIGURA $5)$.

Embora a proteína produzida também seja capaz de ser reconhecida por anticorpos específicos de forma comparável àquela produzida com os protocolos mais eficientes descritos (Amorim et al., 2010), infelizmente o fato dela ter de ser mantida em 2M de Uréia mostrou-se tóxico para células em cultura, inviabilizando sua utilização em ensaios celulares. Em consequência disto, optamos por seguir com nossos ensaios celulares utilizando somente o peptídeo descrito por Gao et al. (2008).

FIGURA 5 - A proteína NS1 recombinante produzida por nosso grupo possui tamanho e pureza comparáveis à proteína controle.

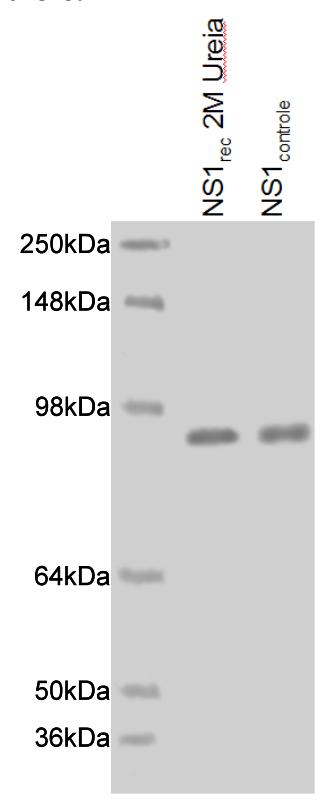

A proteína recombinante em 2M Uréia foi mantida em condições não-redutoras. O gel SDS-PAGE $12 \%$ mostra a banda referente à proteína em sua forma dimérica $(84 \mathrm{kDa})$, semelhante à banda de uma proteína NS1 recombinante controle.

Fonte: Rezende (2012) 


\subsection{Avaliação da resposta de células $\mathrm{T}^{\mathrm{CD8}^{+}}$após a imunização com os anticorpos quiméricos na presença de diferentes estímulos de maturação para DCs.}

A presença de Uréia em nossa proteína recombinante, apesar de permitir a realização de ensaios de ELISA, não permitiu que fizéssemos muitos ensaios celulares devido à sua toxicidade em cultura. Nossas tentativas de conseguir mapear algum epitopo $\mathrm{CD}^{+}$da NS1 também foram infrutíferas: mandamos sintetizar alguns peptídeos baseados em programa de predição de epitopos como PredBALB e SYFPEITHI. Infelizmente nenhum dos peptídeos sintetizados foi eficientemente reconhecido pelas Células $\mathrm{T} \mathrm{CD}^{+}$dos animais imunizados (dados não mostrados).

Resolvemos então focar nossa atenção na resposta de Células $\mathrm{T} \mathrm{CD}^{+}$já que havia um peptídeo reconhecido pelo MHC I de camundongos BALB/c já descrito na literatura (Gao et $a l ., 2008)$. Iniciamos então experimentos de imunização dos camundongos que envolveram a

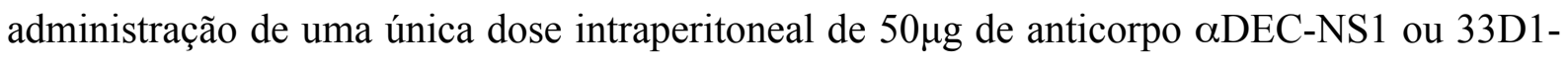
NS1 mais agonista em grupos de cinco camundongos fêmeas. Tal concentração já havia sido previamente utilizada em outros trabalhos de nosso grupo com sucesso. O veículo utilizado foi salina estéril e o estímulo de maturação das DCs (adjuvante) variou entre Poly I:C (FIGURA 6), CpG (FIGURA 7) e MDP (FIGURA 8). Como controle, utilizamos um grupo administrado somente com o adjuvante em questão.

Avaliamos a resposta celular em culturas de esplenócitos que foram reestimuladas com o peptídeo CD8 descrito (AGPWHLGKL, Gao et al., 2008), ou com um peptídeo controle não-relacionado denominado PASTOR (Rosa et al., 2006)

Analisando separadamente os resultados deste experimento, podemos observar que, quando imunizamos os camundongos utilizando Poly I:C como estímulo de maturação para DCs, detectamos uma resposta de células $\mathrm{T} \mathrm{CD} 8^{+}$específica, principalmente nos animais imunizados com o anticorpo quimérico $\alpha$ DEC-NS1 (FIGURA 6).

Por outro lado, quando o estímulo de maturação utilizado foi $\mathrm{CpG}$, cujo receptor, TLR9, é semelhantemente expresso por ambas populações, temos um perfil semelhante de resposta entre os grupos imunizados com $\alpha \mathrm{DEC}-\mathrm{NS} 1$ ou 33D1-NS1, indicando que ambas as populações de DCs são capazes de realizar apresentação cruzada (FIGURA 7). 
FIGURA 6 - Direcionamento da NS1 para as DCs DEC $205^{+}$em presença de Poly I:C induz um maior número de células $\mathrm{T} \mathrm{CD8}^{+}$produtoras de IFN- $\gamma$ do que o direcionamento para as DCs DCIR2 ${ }^{+}$.

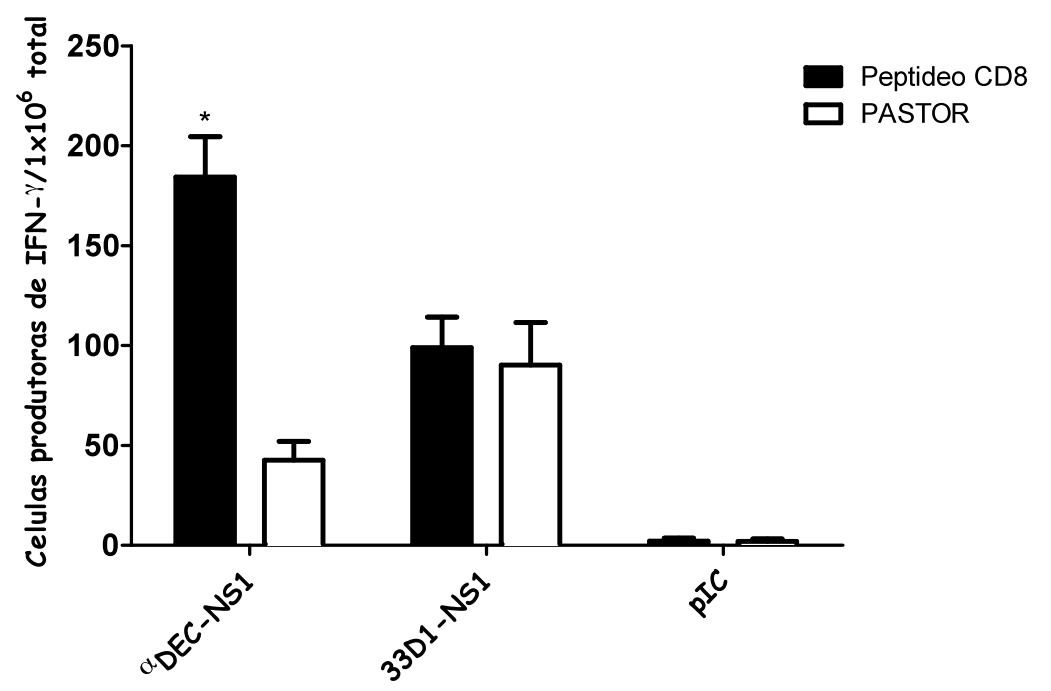

Ensaio de ELISPOT em que esplenócitos de camundongos BALB/c imunizados com 50 $\mu \mathrm{g}$ dos anticorpos quiméricos $\alpha$ DEC-NS1 ou 33D1-NS1 em presença de $50 \mu \mathrm{g}$ de Poly I:C, ou somente com Poly I:C, foram incubados na presença de $5 \mu \mathrm{g} / \mathrm{mL}$ dos peptídeos CD8 ou PASTOR (como controle negativo). O gráfico mostra o número de células produtoras de IFN- $\gamma$ por milhão de esplenócitos. As barras representam as médias \pm errospadrão de 4 experimentos feitos em triplicata. * representa diferença significativa e $p<0.05$.

Fonte: Rezende (2012)

FIGURA 7 - Direcionamento da NS1 para as DCs $\mathrm{DEC205}^{+}$ou $\mathrm{DCIR2}^{+}$em presença de CpG induz números semelhantes de células $\mathrm{T} \mathrm{CD8}^{+}$produtoras de IFN- $\gamma$.

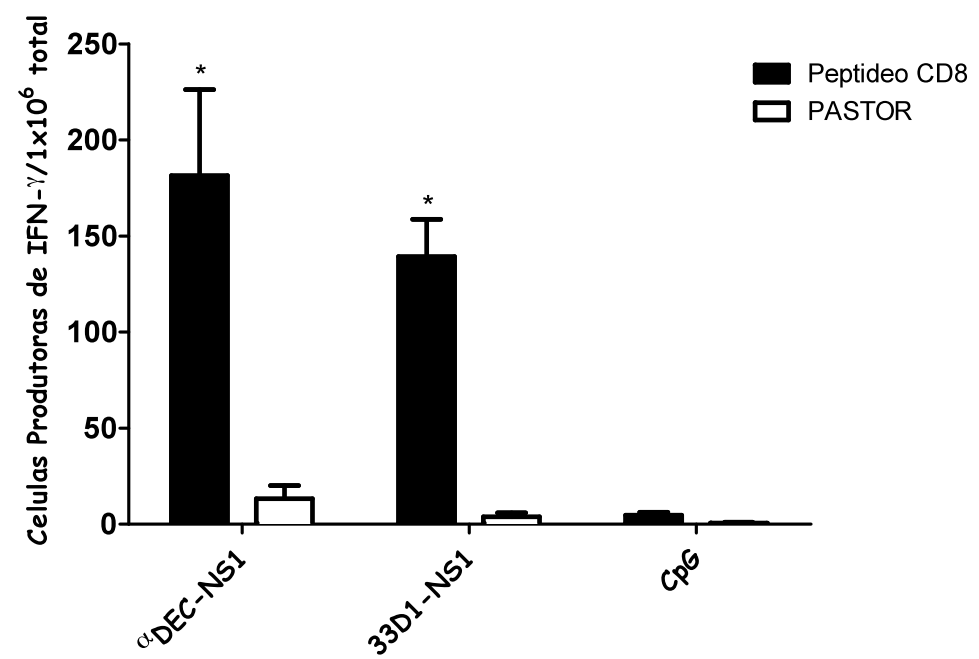

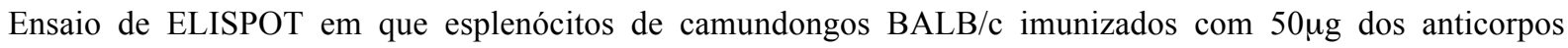
quiméricos $\alpha$ DEC-NS1 ou 33D1-NS1 em presença de $25 \mu \mathrm{g}$ de $\mathrm{CpG}$, ou somente com $\mathrm{CpG}$, foram incubados na presença de $5 \mu \mathrm{g} / \mathrm{mL}$ dos peptídeos CD8 ou PASTOR (como controle negativo). O gráfico mostra o número de células produtoras de IFN- $\gamma$ por milhão de esplenócitos. As barras representam as médias \pm erros-padrão de 4 experimentos feitos em triplicata. * representa diferença significativa e $\mathrm{p}<0.001$ em relação ao peptídeo controle.

Fonte: Rezende (2012) 
Finalmente, quando utilizamos como agonista MDP, uma molécula capaz de ativar vias de sinalização independentes de TLRs e dependentes de NLRs (NOD2 e NALP3), não observamos uma resposta expressiva no grupo de animais imunizados com $\alpha$ DEC-NS1, mas observamos alguma resposta no grupo imunizado com 33D1-NS1 (FIGURA 8).

FIGURA 8 - Em presença de MDP, o direcionamento da NS1 para as DCs DCIR2 ${ }^{+}$induz maior número de células $\mathrm{T} \mathrm{CD8}^{+}$produtoras de IFN- $\gamma$ quando comparado ao direcionamento para as DCs $\mathrm{DEC205}^{+}$.

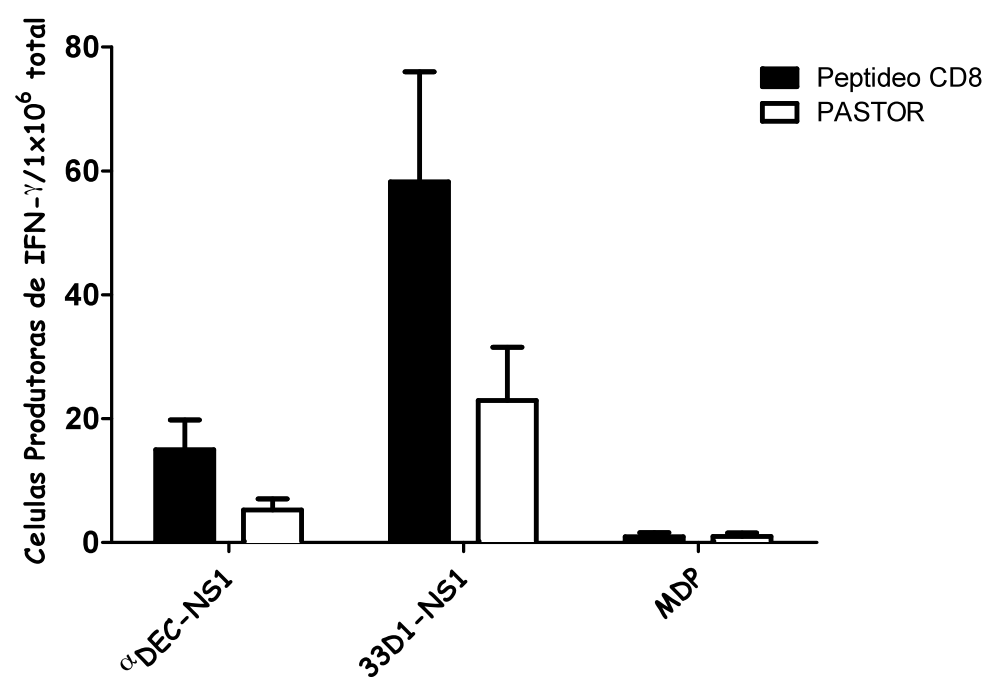

Ensaio de ELISPOT em que esplenócitos de camundongos BALB/c imunizados com 50 $\mu \mathrm{g}$ dos anticorpos quiméricos $\alpha$ DEC-NS1 ou 33D1-NS1 em presença de $100 \mu \mathrm{g}$ de MDP, ou somente com MDP, foram incubados na presença de $5 \mu \mathrm{g} / \mathrm{mL}$ dos peptídeos CD8 ou PASTOR (como controle negativo). O gráfico mostra o número de células produtoras de IFN- $\gamma$ por milhão de esplenócitos. As barras representam as médias \pm erros-padrão de 4 experimentos feitos em triplicata.

Fonte: Rezende (2012)

\subsection{Avaliação da resposta humoral anti-NS1 após a administração de uma dose dos anticorpos quiméricos na presença de diferentes estímulos de maturação para DCs.}

Os soros dos animais imunizados para realização dos experimentos descritos na seção anterior foram também utilizados em ensaios de ELISA para avaliarmos a produção de anticorpos anti-NS1. É importante ressaltar que neste caso estamos observando a resposta primária de anticorpos. Desta forma, observamos uma resposta humoral maior nos animais injetados com 33D1-NS1 e uma resposta mais baixa nos animais injetados com $\alpha$ DEC-NS1. Além disto, a injeção do agonista Poly I:C suscitou os níveis mais altos de títulos de anticorpos, enquanto que os menores títulos foram observados quando a injeção foi realizada na presença de MDP. Os grupos injetados com $\mathrm{CpG}$ apresentaram títulos intermediários entre os outros agonistas (FIGURA 9). 
FIGURA 9 - Imunização com anticorpos quiméricos associados à proteína NS1 induz resposta humoral, principalmente nos animais imunizados com Poly I:C e CpG.

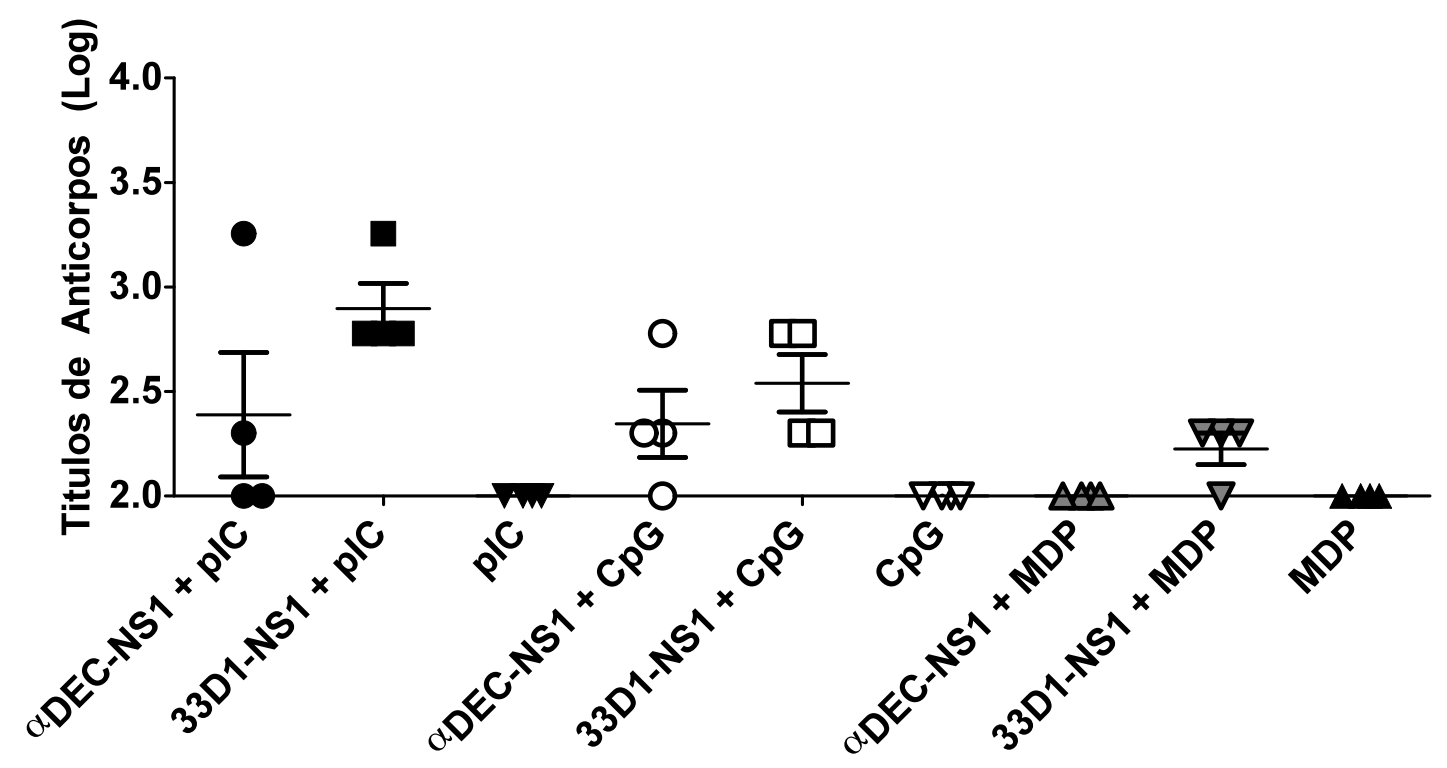

Títulos de anticorpos 7 dias depois da dose única de imunização. Os grupos que receberam anticorpos quiméricos apresentaram níveis detectáveis de anticorpos IgG séricos anti-NS1. Cada símbolo representa um animal e as barras horizontais representam as médias \pm desvio padrão.

Fonte: Rezende (2012)

\subsection{Avaliação da proteção conferida pela imunização de camundongos com os anticorpos quiméricos.}

Concomitante aos experimentos descritos acima, realizamos experimentos de desafio dos animais imunizados com os anticorpos quiméricos. Nestes experimentos, contudo, quisemos avaliar a eficácia de um protocolo prime-boost mais próximo de um protocolo de imunização que poderia ser utilizado em humanos. Primeiramente imunizamos os animais (prime) com $5 \mu \mathrm{g}$ dos anticorpos quiméricos ( $\alpha \mathrm{DEC}-\mathrm{NS} 1$ ou 33D1-NS1 ou $\alpha \mathrm{DEC}-\varnothing$ ou 33D1ø) na presença de Poly I:C. Os anticorpos $\alpha$ DEC-ø e 33D1-ø foram produzidos e testados da mesma forma que os demais anticorpos quiméricos, e consistem nos anticorpos, com a cadeia linker, sem a presença de qualquer proteína de interesse associada. Após um mês da primeira injeção, foi administrada uma segunda dose (boost) idêntica à primeira. Aos 14 dias pós-boost os animais foram sangrados para avaliação dos títulos de anticorpos anti-NS1 (idênticos entre os grupos imunizados com $\alpha$ DEC-NS1 ou 33D1-NS1 - FIGURA 10) e enviados para o experimento de Desafio. Tais experimentos, realizados na Fundação Oswaldo Cruz, sob supervisão da Prof. Ada Maria de Barcelos Alves, consistiram na injeção intracerebral de DENV2 nos animais (LD50), para análise de morbidade e mortalidade nos 21 dias 
subsequentes. Surpreendentemente, somente os animais do grupo imunizado com $\alpha$ DEC-NS1 apresentaram proteção significativamente maior que os controles (FIGURA 11). Também em relação à morbidade, os animais do grupo $\alpha$ DEC-NS1 apresentaram menos sintomas graves, comparados aos animais dos demais grupos (FIGURA 12).

FIGURA 10 - Imunização com 2 doses de $5 \mu$ g dos anticorpos quiméricos associados à proteína NS1 na presença de poly I:C induz forte resposta humoral.

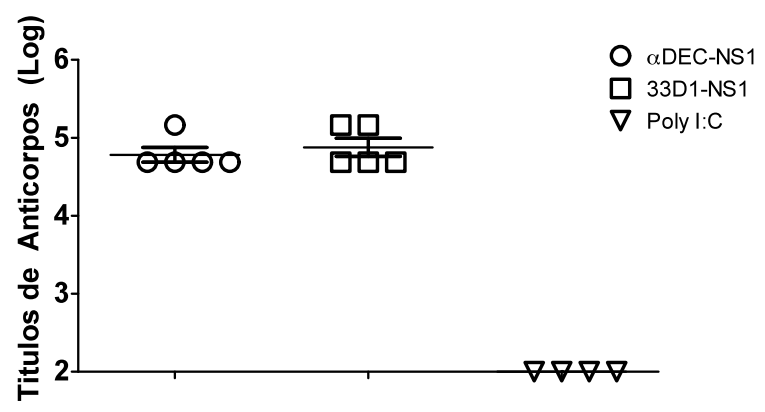

Títulos de anticorpos 14 dias depois da administração da segunda dose de imunização. Os grupos que receberam anticorpos quiméricos apresentaram níveis detectáveis de anticorpos IgG séricos anti-NS1. Cada símbolo representa um animal e as barras horizontais representam a médias \pm desvio padrão.

Fonte: Rezende (2012)

FIGURA 11 - Imunização com o anticorpo quimérico aDEC-NS1 na presença de Poly I:C é capaz de proteger parcialmente os animais do desafio com o vírus DENV2.

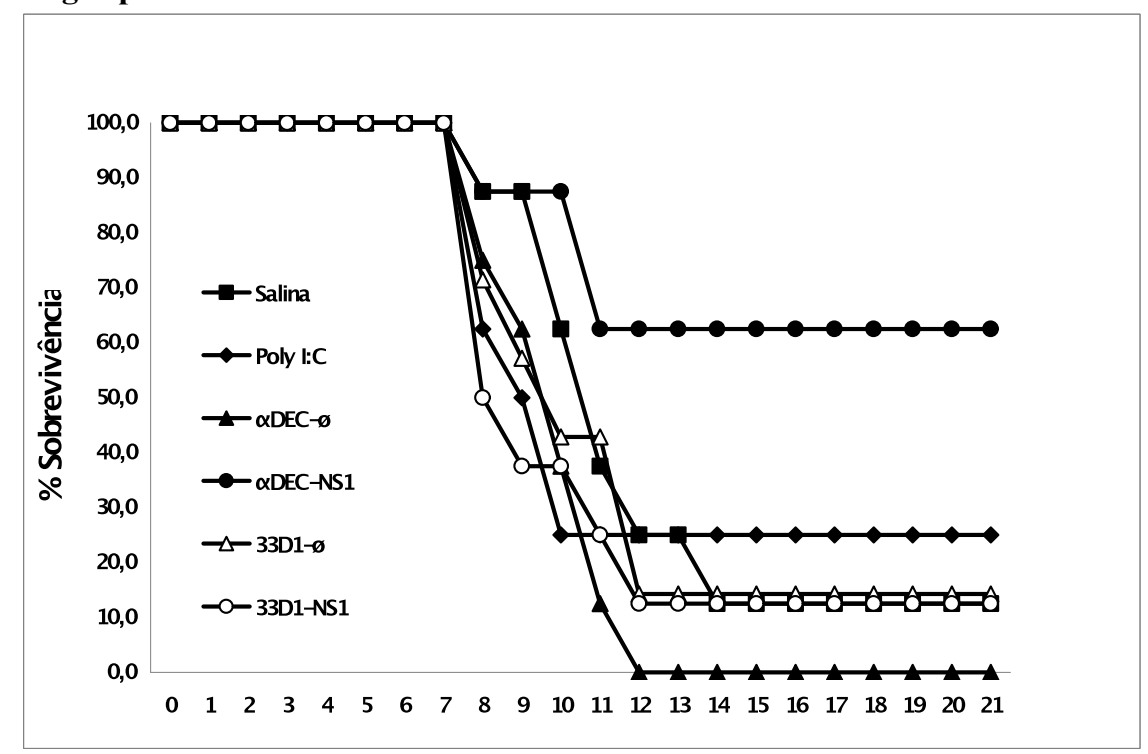

Ensaio de sobrevivência mostrando a porcentagem de animais vivos. Grupos de 8 camundongos BALB/c foram

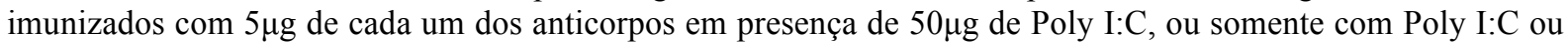
veículo. Um mês após a administração da primeira dose, os animais receberam uma dose de reforço. Quatorze dias após a administração do reforço, os animais foram desafiados intracranialmente com o vírus DENV2 NGC. A mortalidade foi acompanhada diariamente por 21 dias.

Fonte: Rezende (2012) 
FIGURA 12 - Animais imunizados com o anticorpo quimérico aDEC-NS1 apresentam menor morbidade após o desafio quando comparados ao animais imunizados com os demais anticorpos.

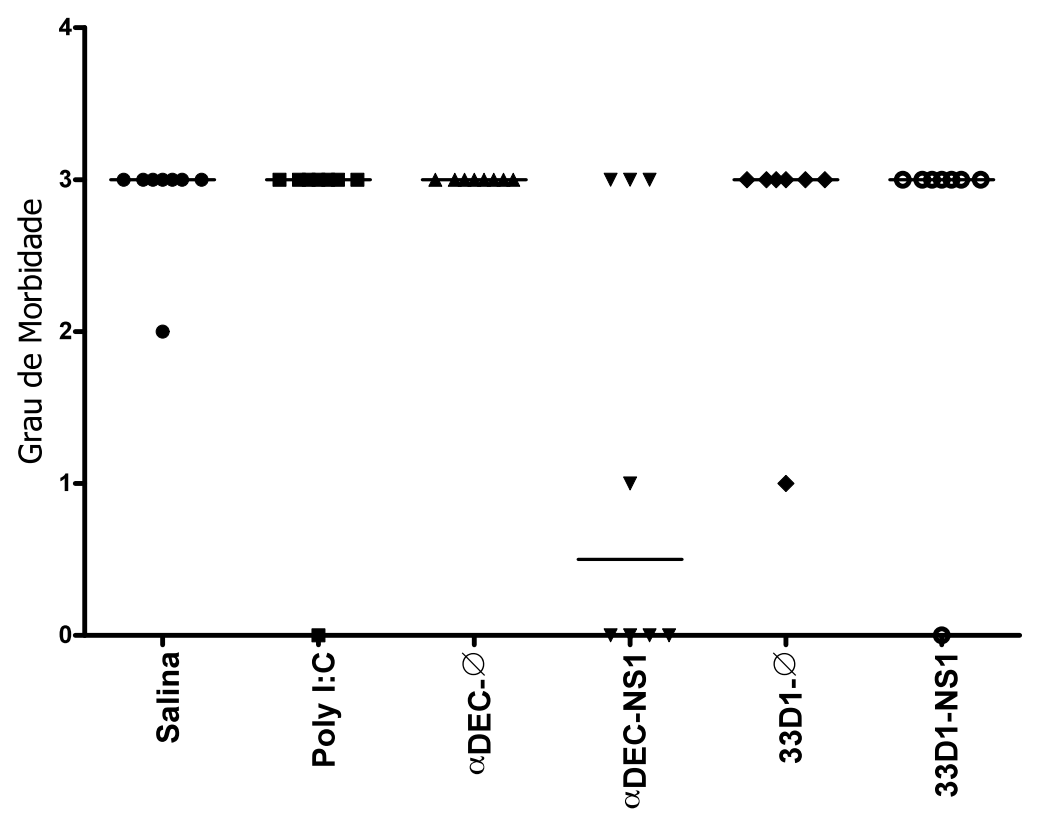

Gráfico comparativo do grau de morbidade dos animais de cada grupo no $21^{\circ}$ dia após o desafio. Os grupos consistiam de 8 animais imunizados com cada um dos anticorpos quiméricos mais adjuvante ou somente adjuvante ou veículo.

Fonte: Rezende (2012)

Tendo em vista a proteção conferida pela imunização com $\alpha$ DEC-NS1, resolvemos investigar que tipo celular poderia estar envolvido neste fenômeno. Decidimos então repetir o experimento anterior, incluindo grupos imunizados com $\alpha \mathrm{DEC}-\mathrm{NS} 1$ e que, no dia anterior ao desafio, seriam depletados de Linfócitos $\mathrm{T} \mathrm{CD}^{+}$ou $\mathrm{CD}^{+}$, através da injeção retro-ocular de anticorpos $\alpha \mathrm{CD} 4$ ou $\alpha \mathrm{CD} 8$, respectivamente. Com este experimento, pretendíamos avaliar a importância de cada uma destas populações na proteção conferida por nosso protocolo de imunização.

Os resultados de mortalidade dos animais (FIGURA 13) confirmam que a imunização com $\alpha$ DEC-NS1 confere proteção à infecção por DENV2 maior que a observada nos grupos controle, o mesmo não sendo observado para o grupo imunizado com 33D1-NS1. No entanto, tanto a depleção da população de Linfócitos $\mathrm{T} \mathrm{CD}^{+}$quanto de $\mathrm{CD} 8^{+}$levou a uma diminuição desta proteção. Além disso, o gráfico de morbidade (FIGURA 14) nos permite especular que a depleção da população $\mathrm{CD}^{+}$causou mais dano, sendo que todos os animais deste grupo evoluíram para o grau 3 de morbidade, enquanto que 62,5\% dos animais depletados da população $\mathrm{CD}^{+}$evoluíram para este grau de morbidade, indicando que ainda possuíam certo nível de proteção conferida pela imunização. 
Tal resultado nos faz pensar que devem haver epitopos para Linfócitos $\mathrm{T}_{\mathrm{CD}} 4^{+}$na molécula NS1 que estejam sendo reconhecidos e que são capazes de conferir proteção. Contudo, nenhum dos epitopos preditos que testamos foi capaz de induzir a produção de IFN$\gamma$ por células $\mathrm{T} \mathrm{CD}^{+}$em ensaios de ELISPOT (dados não mostrados).

FIGURA 13 - A depleção das populações de células $\mathrm{T} \mathrm{CD4}^{+}$e $\mathrm{TCD8}^{+}$reduz a proteção conferida pela imunização com o anticorpo quimérico $\alpha$ DEC-NS1 na presença de Poly I:C.

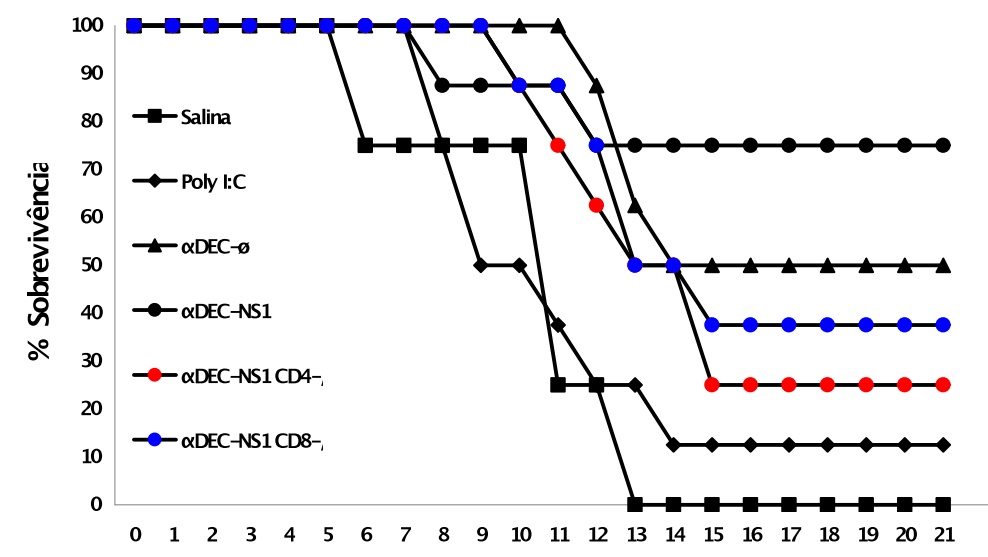

Ensaio de sobrevivência mostrando a porcentagem de animais vivos. Grupos de 8 animais foram imunizados como descrito na figura 10. Um dia antes do desafio, dois grupos de animais que foram imunizados com o anticorpo $\alpha \mathrm{DEC}$-NS1+Poly I:C foram tratados com $100 \mu \mathrm{g}$ dos anticorpos anti-CD4 (triângulos invertidos vermelhos) ou anti-CD8 (triângulos invertidos azuis) para depleção desta populações linfocitárias. A mortalidade foi acompanhada até o dia 21 após o desafio.

Fonte: Rezende (2012)

FIGURA 14 - Grau de morbidade dos animais desafiados com DENV2 após imunização com anticorpos quiméricos na presença de Poly I:C.

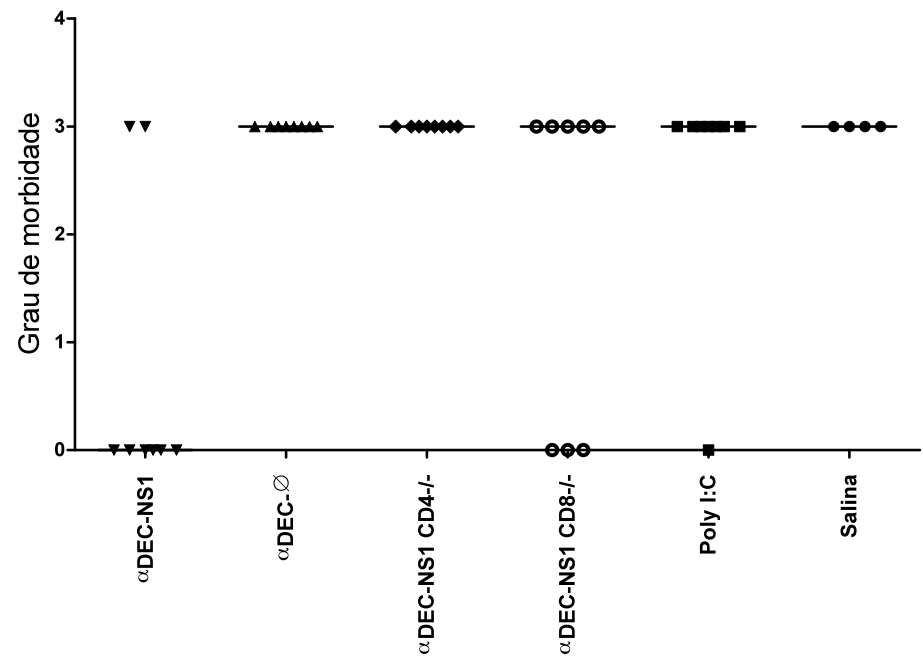

Gráfico comparativo do grau de morbidade dos animais de cada grupo no $21^{\circ}$ dia após o desafio. Os grupos consistiam de 8 animais imunizados com cada um dos anticorpos quiméricos mais adjuvante ou somente adjuvante ou veículo. Grupos de animais imunizados com $\alpha$ DEC-NS1 foram depletados das populações de células $\mathrm{CD}^{+}$ou $\mathrm{CD}^{+}$no dia anterior ao desafio.

Fonte: Rezende (2012) 


\subsection{Avaliação das respostas de células $\mathrm{T} \mathrm{CD4}^{+}$ao peptídeo PADRE em camundongos imunizados com os anticorpos quiméricos contendo a proteína MSP1 $1_{19}$-PADRE.}

Embora tenhamos indícios da importância da resposta de Linfócitos $\mathrm{T} \mathrm{CD}^{+}$na proteção conferida por nosso protocolo de imunização com os anticorpos quiméricos associados a NS1, não conseguimos, por causa das dificuldades mencionadas anteriormente, analisar tais respostas. Desta forma, para comparar as respostas de células $\mathrm{T} \mathrm{CD}^{+}$das duas principais populações de cDCs do baço quando antígenos são direcionados a cada uma destas na presença de diferentes agonistas, decidimos utilizar um modelo já estabelecido em nosso laboratório de imunização de camundongos C57BL/6 com os anticorpos $\alpha \mathrm{DEC}-\mathrm{MSP} 1_{19^{-}}$ PADRE ou 33D1-MSP1 19 -PADRE (Barbosa, 2011). O peptídeo sintético PADRE é um potente estimulador de respostas de Linfócitos T CD4 ${ }^{+}$, descrito por Alexander et al. (1994), e foi utilizado em nossos experimentos, para que obtivéssemos uma boa resolução de resposta $T$ $\mathrm{CD} 4^{+}$-específica.

Tal experimento consistiu na injeção (prime) de $5 \mu \mathrm{g}$ de um dos anticorpos quiméricos

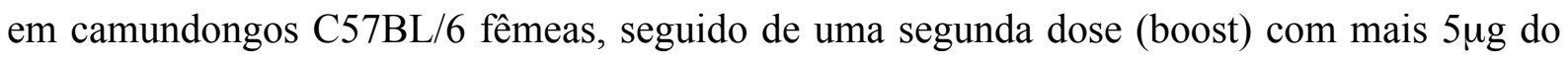
mesmo anticorpo 28 dias após a primeira dose. Tanto o prime quanto o boost foram injetados intraperitonialmente, e tiveram salina como veículo. Utilizamos Poly I:C como agonista em metade dos grupos e $\mathrm{CpG}$ na outra metade, para que pudéssemos comparar as respostas obtidas.

Além das respostas $\mathrm{CD}^{+}$-específicas, também analisamos a resposta humoral dos animais, através da detecção de anticorpos IgG específicos para a proteína MSP $1_{19}$ nos soros dos animais 7 dias após o boost. Assim como para a proteína NS1, quando utilizamos Poly I:C ou CpG como agonista, os grupos apresentaram títulos muito semelhantes de anticorpos, independente do anticorpo quimérico com o qual foram injetados (FIGURA 15).

Em seguida, para avaliarmos a resposta celular ao peptídeo PADRE, os animais foram sacrificados, os baços retirados e macerados e os esplenócitos cultivados na presença de diferentes estímulos. Quando analisamos o número de células produtoras de IFN- $\gamma$, através do ensaio de ELISPOT, novamente observamos que nos animais imunizados na presença de Poly I:C a resposta ao peptídeo PADRE dos animais injetados com $\alpha$ DEC foi significativamente maior que a resposta observada nos demais grupos, embora possamos observar uma pequena resposta no grupo injetado com o anticorpo 33D1 (FIGURA 16.A). Quando o agonista

utilizado foi $\mathrm{CpG}$, observamos um padrão bem diferente, onde somente observamos um 
modesto número de células produtoras de IFN- $\gamma$ no grupo de animais injetados com 33D1 (FIGURA 16.B).

FIGURA 15 - Imunização com anticorpos quiméricos associados a proteína MSP1 19 -PADRE induz resposta humoral, independente do agonista utilizado.

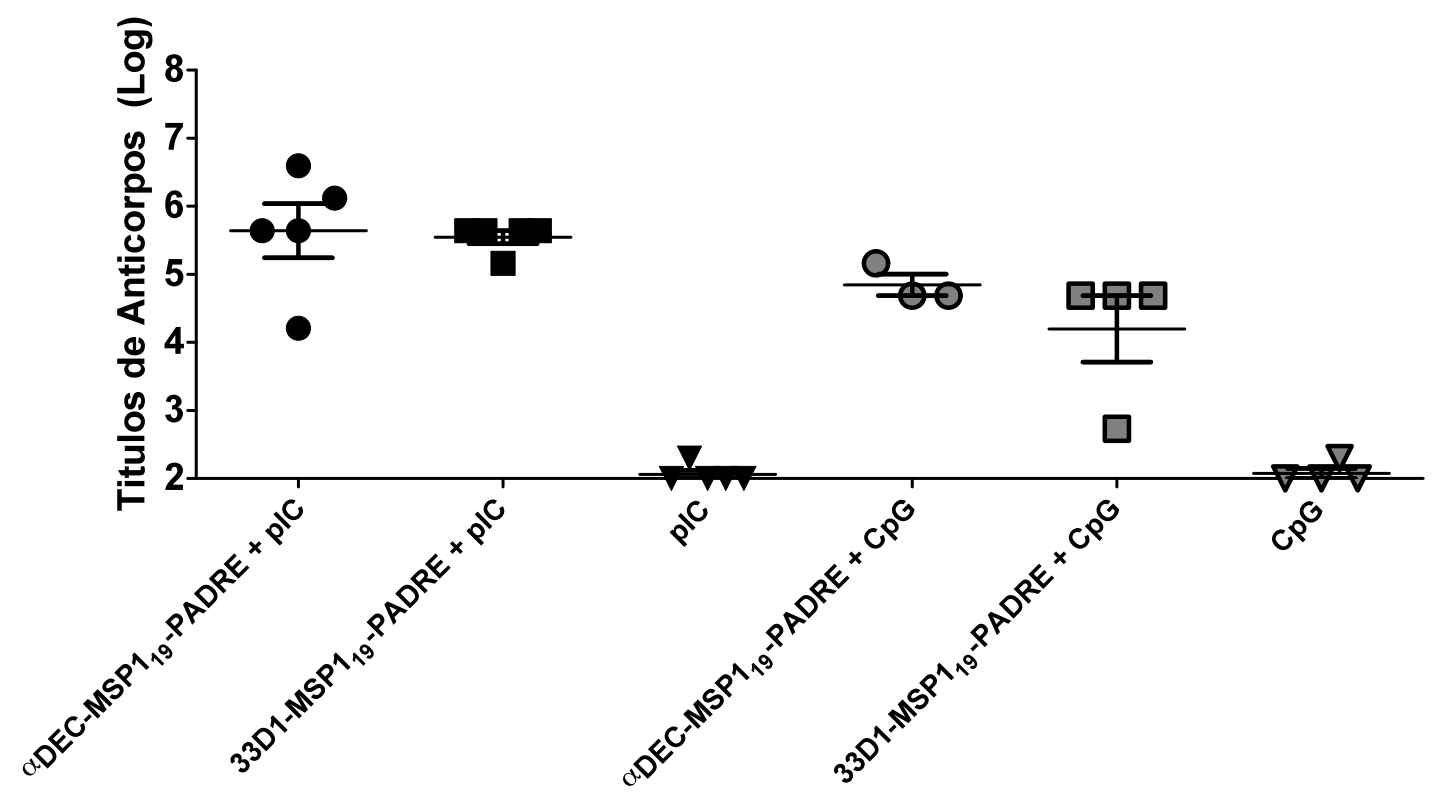

Títulos de anticorpos 7 dias depois (pós-boost) da segunda dose da imunização. Os grupos que receberam anticorpos quiméricos apresentaram altos níveis de anticorpos IgG séricos anti-MSP1 19 . Cada símbolo representa um animal e as barras horizontais representam a médias \pm desvio padrão.

Fonte: Rezende (2012)

FIGURA 16 - Produção de IFN- $\gamma$ contra peptídeo PADRE induzida pela imunização com anticorpos quiméricos na presença de diferentes agonistas.

A)

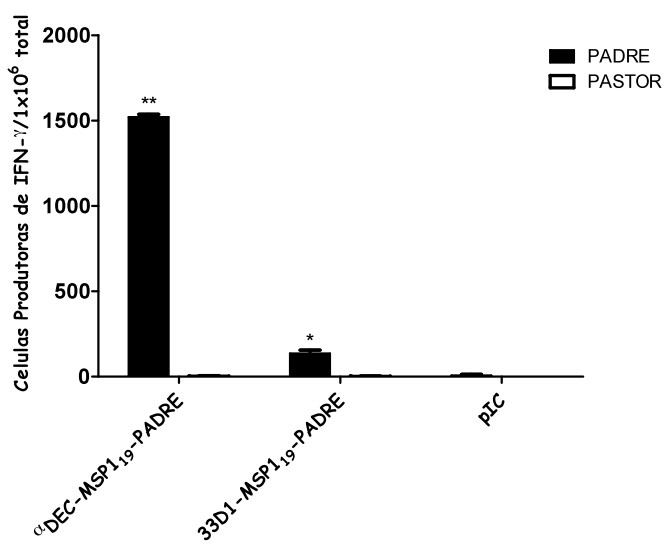

B)

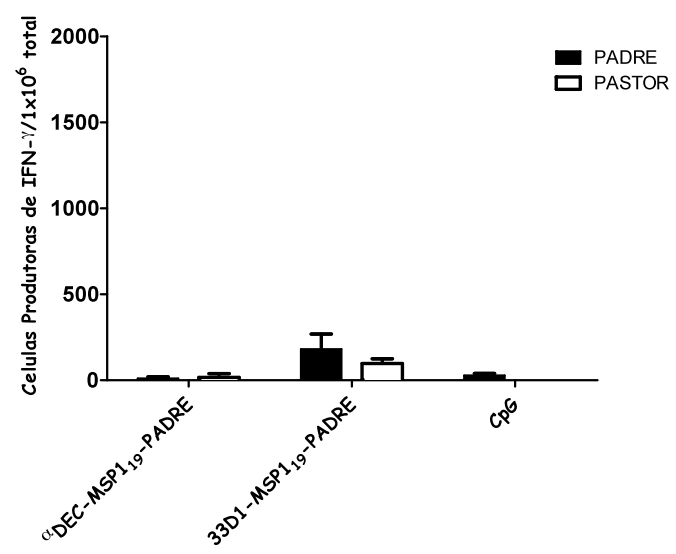

Ensaio de ELISPOT mostrando o número de células produtoras de IFN- $\gamma$ por milhão de esplenócitos após reestímulo com o peptídeo PADRE quando o agonista utilizado na imunização foi Poly I:C (A) ou CpG (B). As barras representam as médias \pm desvio-padrão de um experimento feito em triplicata. ** representa diferença significativa de todos os demais grupos e $\mathrm{p}<0.001$. * representa diferença significativa de todos os demais grupos e $\mathrm{p}<0.01$.

Fonte: Rezende (2012) 
Analisamos também a proliferação de Linfócitos T $\mathrm{CD}^{+}$, através da técnica de CFSE, após a re-estimulação in vitro com o peptídeos PADRE ou um peptídeo não-relacionado PASTOR. Nos grupos de animais injetados na presença de Poly I:C, novamente observamos uma proliferação consideravelmente maior no grupo injetado com $\alpha \mathrm{DEC}$ que naquele injetado com 33D1 (FIGURA 17.A). Contudo, nos grupos injetados na presença de CpG, embora novamente a resposta seja bem menor que na presença de Poly I:C, os grupos injetados com $\alpha \mathrm{DEC}$ ou com 33D1 apresentaram proliferação muito semelhante (FIGURA 17.B).

FIGURA 17 - Proliferação de Linfócitos T $\mathrm{CD4}^{+}$re-estimulados in vitro com peptídeo PADRE induzida pela imunização com anticorpos quiméricos na presença de diferentes agonistas.

A)

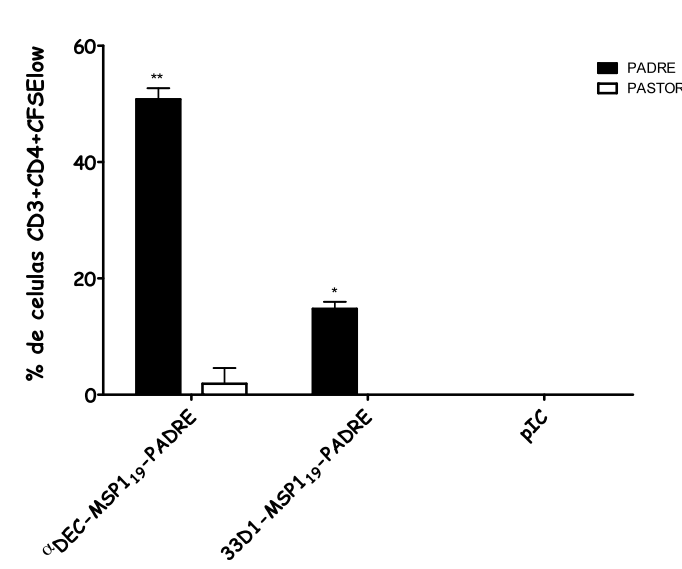

B)

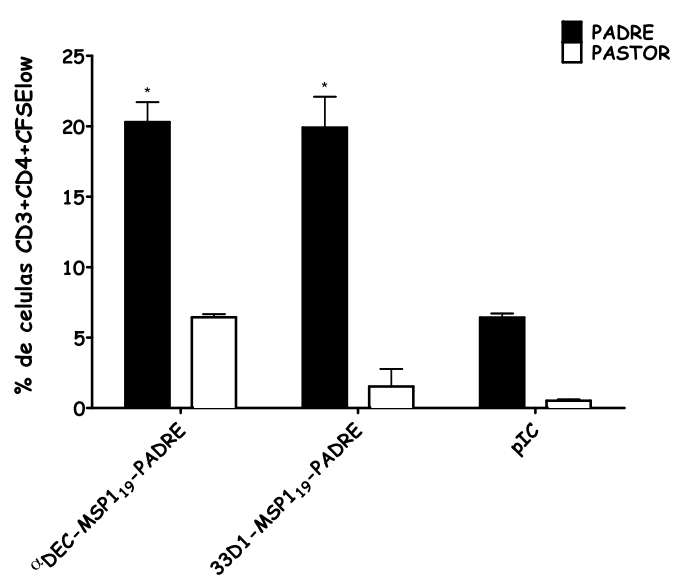

Ensaio de CFSE mostrando a proliferação de linfócitos T $\mathrm{CD}^{+}$sob estímulo do peptídeo PADRE ou PASTOR (controle negativo) quando o agonista utilizado na imunização foi Poly I:C (A) ou $\mathrm{CpG}$ (B). As barras representam as médias \pm desvio-padrão de um experimento feito em duplicata. ${ }^{* *}$ representa diferença significativa de todos os demais grupos e $\mathrm{p}<0.001 . *$ representa diferença significativa de todos os demais grupos e $\mathrm{p}<0.05$.

Fonte: Rezende (2012)

Por fim, também analisamos pelo método de Intracellular Staining (ICS) a expressão de algumas citocinas tipicamente associadas a uma resposta imune tipo Th1 por linfócitos $\mathrm{T}$ $\mathrm{CD}^{+}$do baço dos camundongos imunizados com os diferentes anticorpos quiméricos na presença dos agonistas Poly I:C ou CpG.

Novamente, quando Poly I:C foi utilizado como agonista, somente observamos uma resposta robusta nos animais imunizados com $\alpha \mathrm{DEC}$, seja quando analisamos a expressão de IFN- $\gamma$ (FIGURA 18.A), IL-2 (FIGURA 19.A) ou TNF- $\alpha$ (FIGURA 20.A).

Quando CpG foi utilizado como agonista, a resposta, de uma forma geral, mostrou-se bem menos pronunciada e muito mais variável do que quando utilizamos Poly I:C. Em 
relação a produção de IFN- $\gamma$, observamos uma pequena resposta nos grupos imunizados com aDEC e com 33D1 (FIGURA 18.B).

FIGURA 18 - Porcentagem de Linfócitos T CD4 ${ }^{+}$expressando IFN- $\gamma$ após re-estimulação in vitro com peptídeo PADRE induzida pela imunização com anticorpos quiméricos na presença de diferentes agonistas.

A)

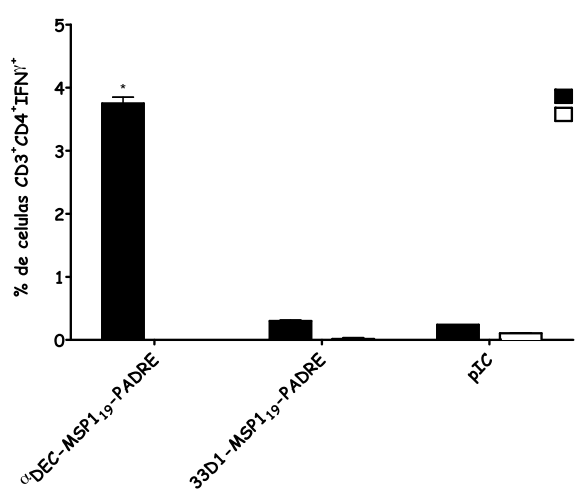

B

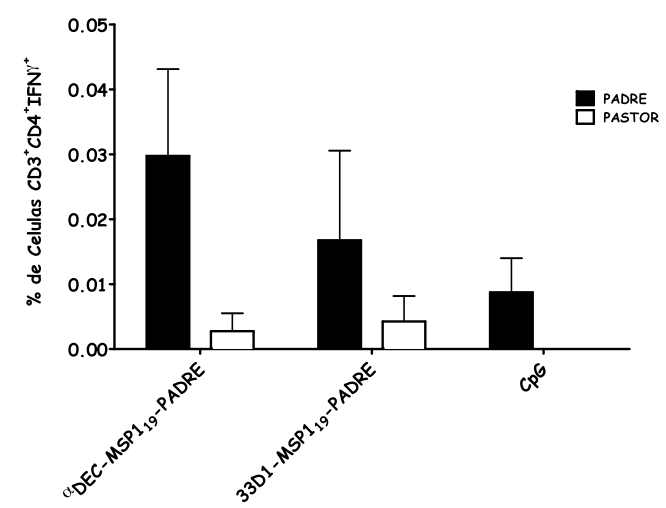

Ensaio de ICS mostrando a porcentagem de linfócitos T $\mathrm{CD}^{+}$expressando IFN- $\gamma$ após estímulo dos peptídeos PADRE ou PASTOR (controle negativo) quando o agonista utilizado na imunização foi Poly I:C (A) ou CpG (B). As barras representam as médias \pm erro-padrão de dois experimentos feitos em duplicata. * representa diferença significativa e $\mathrm{p}<0.001$.

Fonte: Rezende (2012)

Também diferente de Poly I:C, quando analisamos a expressão de IL-2 quando CpG foi utilizado como agonista, observamos uma resposta ao re-estímulo com PADRE em todos os grupos, inclusive no grupo controle (FIGURA 19.B).

FIGURA 19 - Porcentagem de Linfócitos $\mathrm{T} \mathrm{CD4}^{+}$expressando IL-2 após re-estimulação in vitro com peptídeo PADRE induzida pela imunização com anticorpos quiméricos na presença de diferentes agonistas.

A)

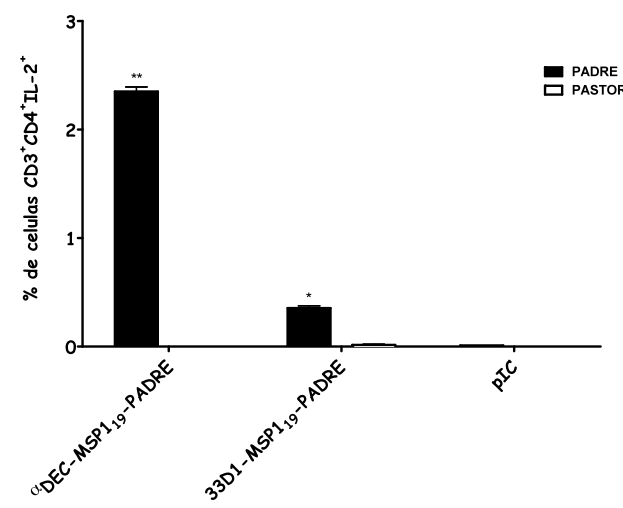

B)

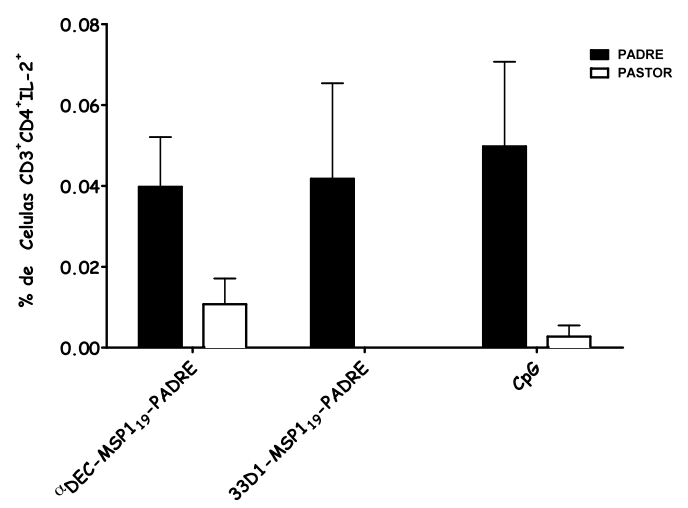

Ensaio de ICS mostrando a porcentagem de linfócitos T CD4+ expressando IL-2 após estimulo do peptídeo PADRE quando o agonista utilizado na imunização foi Poly I:C (A) ou CpG (B). As barras representam as médias \pm desvio-padrão de um experimento feito em duplicata. ** representa grupos com diferença significativa em relação aos demais e $\mathrm{p}<0.001$. * representa grupos com diferença significativa e $\mathrm{p}<0.01$.

Fonte: Rezende (2012) 
Também analisamos a produção de TNF- $\alpha$ e, assim como a expressão de IFN- $\gamma$, a imunização com $\mathrm{CpG}$ como agonista resultou em níveis consideravelmente mais baixos, comparados com Poly I:C, mas novamente detectamos a expressão da citocina nos grupos imunizados com $\alpha$ DEC e com 33D1 (FIGURA 20.B).

FIGURA 20 - Porcentagem de Linfócitos T CD4 ${ }^{+}$expressando TNF- $\alpha$ após re-estimulação in vitro com peptídeo PADRE induzida pela imunização com anticorpos quiméricos na presença de diferentes agonistas.

A)

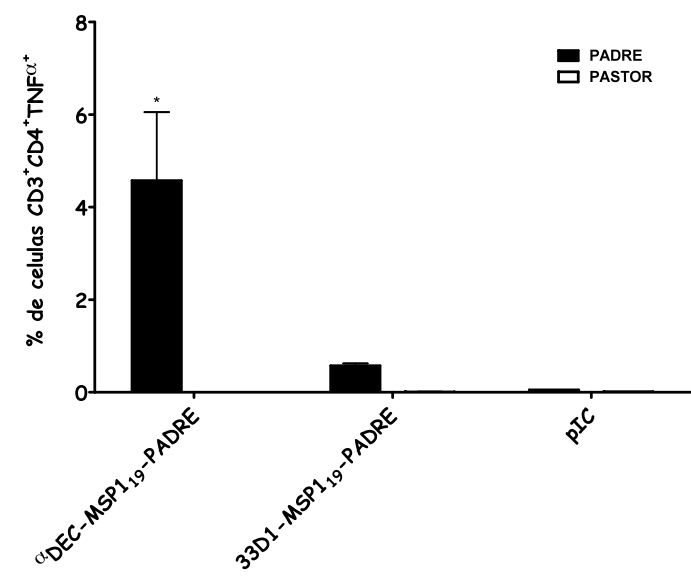

B)

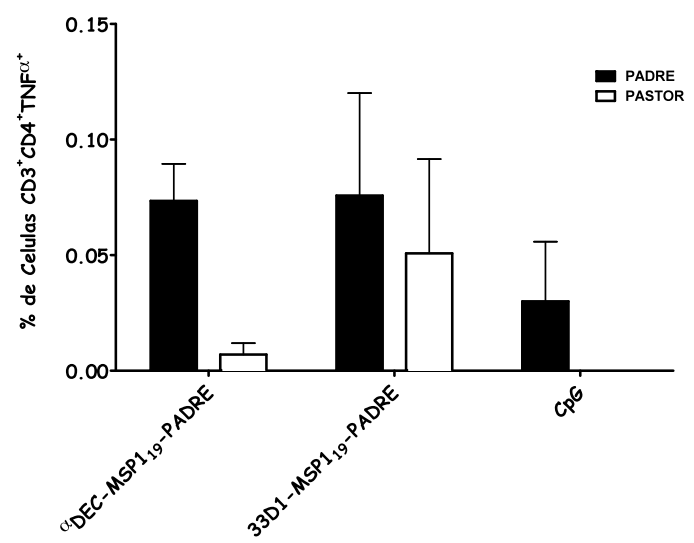

Ensaio de ICS mostrando a porcentagem de linfócitos T CD4 $4^{+}$expressando TNF- $\alpha$ após estímulo do peptídeo PADRE quando o agonista utilizado na imunização foi Poly I:C (A) ou CpG (B). As barras representam as médias \pm desvio-padrão de um experimento feito em duplicata. * representa diferença significativa e $\mathrm{p}<0.001$. Fonte: Rezende (2012) 
5. DISCUSSÃO 
Conforme demonstramos em nossos resultados, fomos capazes de produzir em larga escala os anticorpos quiméricos associados à proteína NS1 de DENV2, comprovando sua integridade, bem como a conformação da proteína NS1 fusionada a eles. A proteína NS1 é encontrada nativamente principalmente na forma dimérica, sendo que é esta a forma reconhecida pela maioria dos anticorpos do soro de camundongos imunizados com a proteína recombinante, e a perda desta conformação correlaciona-se com uma diminuição quase total da resposta humoral anti-NS1 (Amorim et al., 2010). O fato de nosso anticorpo possuir duas cadeias pesadas fusionadas a NS1 favoreceu a presença da proteína em sua conformação dimérica nativa. De fato, anticorpos de animais imunizados com a proteína NS1 em presença de CFA só foram capazes de reconhecer a proteína NS1 fusionada aos anticorpos quiméricos quando estes anticorpos não foram reduzidos (FIGURA 3B). Quando os mesmos anticorpos foram reduzidos na presença de DTT, o reconhecimento da NS1 foi abolido (dados não mostrados).

Outra preocupação que tínhamos era quanto à manutenção da capacidade de ligação específica dos anticorpos aos seus respectivos receptores. Para analisarmos esta questão, realizamos um ensaio de ligação a partir dos esplenócitos do baço de um camundongo BALB/c. Para tanto, selecionamos as células CD19DX $5^{-} \mathrm{MHCII}^{+} \mathrm{CD} 11 \mathrm{c}^{+}$, que consideramos como o conjunto de células dendríticas, subdividimos este grupo quanto a expressão da cadeia alfa da molécula de CD8, e desta forma identificamos um grupo de DCs $\mathrm{CD}^{+}$(descritas como sendo DEC205 ${ }^{+}$) e outro grupo de DCs $\mathrm{CD}^{-}$(descritas como sendo DCIR2 ${ }^{+}$). De fato, observamos a ligação específica do anticorpo $\alpha \mathrm{DEC}-\mathrm{NS} 1$ ao grupo de $\mathrm{DCs} \mathrm{CD}^{+}$, e do anticorpo 33D1-NS1 (cuja especificidade é dirigida ao receptor DCIR2) ao grupo de DCs CD8- De interesse aqui, temos o fato de que a ligação do anticorpo $\alpha$ DEC-NS1 ao conjunto de células $\mathrm{CD}^{+}$gera um deslocamento do pico de fluorescência de uma forma quase totalitária, demonstrando que de fato há uma forte correlação entre o gate de células que criamos e a população que esperávamos observar. No caso da ligação de 33D1-NS1 ao conjunto de células $\mathrm{CD}^{-}$não observamos este deslocamento generalizado, restando células de nosso gate que não são reconhecidas pelo anticorpo 33D1-NS1. Embora esta observação pudesse ser interpretada de forma a concluir que o anticorpo 33D1-NS1 não seja completamente específico para o receptor DCIR2, nosso grupo acredita que esta observação se dá, na verdade, pela presença de outros tipos de dendríticas além das CD8DCIR2 ${ }^{+}$. Corroboram com esta nossa interpretação dados de outros membros de nosso grupo que observam este mesmo efeito, e outros autores que descrevem diferentes subpopulações de DCs no baço que são negativas para a cadeia $\alpha$ do CD8 e se distinguem pela expressão de 
$\mathrm{CD} 4$, havendo uma população $\mathrm{CD}^{-} \mathrm{CD}^{+}$e uma população duplo negativa (Vremec et al., 2000).

Confirmada a integridade e a especificidade dos anticorpos quiméricos a serem utilizados, restava-nos ainda a produção de uma proteína NS1 recombinante que pudéssemos utilizar em experimentos de titulação de resposta humoral e em ensaios celulares de reestimulação in vitro. Embora tenhamos despendido tempo e esforço neste intuito, a proteína sempre apresentou-se de difícil manuseio. Mesmo sendo a expressão em procariotos apreciável, a NS1 recombinante era sempre encontrada na fração insolúvel obtida após sonicação das bactérias. A solubilização desta fração em Uréia mostrou-se mais eficiente que em GluHCl (Glucosamine Hydrochloride), e obtivemos uma boa quantidade de proteína em PBS $+8 \mathrm{M}$ Uréia por cromatografia em colunas de Níquel. Os maiores entraves, entretanto, encontramos quando tentamos dialisar a proteína para uma solução livre de Uréia. O resultado deste procedimento, realizado de diferentes maneiras, era invariavelmente a precipitação da NS1. Diversos autores já haviam relatado as dificuldades de obtenção e manuseio da proteína NS1, mas curiosamente Amorim et al. (2010), de uma equipe de pesquisadores de nosso Instituto, haviam publicado naquela época uma metodologia inovadora para a produção desta proteína. Quando utilizamos um sistema semelhante ao por eles descrito, conseguimos diluir a proteína até uma concentração limite de $2 \mathrm{M}$ de Uréia na presença de $10 \%$ de Glicerol, sendo que qualquer tentativa que realizamos de diálise da proteína além deste limite resultou novamente na precipitação da mesma. Os motivos pelos quais não fomos capazes de reproduzir exatamente os resultados obtidos por aquele grupo provavelmente se devem a diferenças sutis na metodologia utilizada. Outras estratégias, como a clivagem de anticorpos contendo NS1 por papaína foram testados pra obtenção de uma proteína que gerasse respostas celulares observáveis, sem sucesso (dados não mostrados).

Os problemas que encontramos na produção da proteína NS1 recombinante impediram sua utilização eficaz em ensaios celulares de reestimulação in vitro, sem contudo interferir nos ensaios de titulação da resposta humoral. Para darmos prosseguimento aos ensaios celulares, lançamos mão de uma estratégia distinta que consistiu na utilização de um peptídeo especificamente reconhecido por linfócitos $\mathrm{T} \mathrm{CD}^{+}$que havia sido previamente descrito (Gao et al., 2008). Embora não haja peptídeos da proteína NS1 descritos na literatura que sejam especificamente reconhecidos por linfócitos $\mathrm{T} \mathrm{CD}^{+}$, utilizamos 2 diferentes programas de predição de epítopos - PredBALB e SYFPEITHI - para desenharmos e produzirmos quatro peptídeos correspondentes às regiões da NS1 mais prováveis de serem reconhecidas por este tipo celular. Infelizmente nenhum dos epítopos preditos resultou em respostas satisfatórias em 
nossos ensaios de reestimulação de esplenócitos in vitro. Portanto, seguimos nossos estudos sobre a imunização com anticorpos fusionados a NS1 utilizando somente o peptídeo previamente descrito na literatura (FIGURAS 5-8) e que seria reconhecido por células $\mathrm{T}$ $\mathrm{CD}^{+}$de camundongos $\mathrm{BALB} / \mathrm{c}$.

Uma vez definido o estímulo que utilizaríamos em nossos experimentos celulares, iniciamos nossos protocolos de imunização de camundongos. Após testes diversos, e seguindo resultados prévios de nosso grupo, selecionamos a concentração de $50 \mu \mathrm{g}$ de anticorpo em uma única dose como nosso protocolo básico para avaliação das respostas celulares suscitadas por anticorpos quiméricos fusionados a NS1. Embora este não seja um protocolo provável de ser utilizado em situações de testes em humanos, foi escolhido por evidenciar de forma eficiente as respostas celulares que buscávamos avaliar em um primeiro momento.

Com todos os elementos do nosso sistema definidos e funcionando, partimos para a realização de um grande experimento comparativo, onde injetamos animais com cada um de nossos anticorpos quiméricos: $\alpha$ DEC-NS1 ou 33D1-NS1 na presença de diferentes agonistas. São eles: Poly I:C (sinaliza via TLR3/MDA5), CpG (sinaliza via TLR9) ou MDP (sinaliza via Nalp3/NOD2).

Conforme visto em outros experimentos similares (Hawiger et al., 2001; Bonifaz et al., 2002; Thrumpheller et al., 2006; Boscardin et al., 2006), o direcionamento de antígenos na presença de Poly I:C só é capaz de induzir o fenômeno de cross-priming eficientemente quando o direcionamento tem por alvo a população de DCs $\mathrm{CD} 8^{+} \mathrm{DEC} 205^{+}$. Também em nosso sistema observamos este fenômeno nas mesmas condições previamente relatadas (FIGURA 6).

Células produtoras de IFN- $\gamma$ também foram detectadas nos animais imunizados com o anticorpo 33D1-NS1 na presença de Poly I:C. Porém, esta resposta não foi específica para a NS1 já que praticamente o mesmo número de células foi detectado quando os esplenócitos foram estimulados com o peptídeo PASTOR que não é específico da NS1, e não deveria induzir qualquer resposta apreciável. Este resultado é interessante, mas não inesperado, uma vez que as células dendríticas DCIR2 ${ }^{+}$parecem expressar níveis baixos de TLR3, o principal receptor responsivo ao estímulo com Poly I:C (Edwards et al., 2003). Conforme demonstrado previamente, quando o direcionamento é realizado sem um estímulo concomitante que sinalize para a maturação das DCs, não se observa ativação de linfócitos T específicos para a proteína direcionada mas, ao contrário, pode-se até mesmo induzir tolerância a esta (Hawiger et al., 2001). 
Por outro lado, quando o estímulo de maturação utilizado foi $\mathrm{CpG}$, cujo receptor, TLR9, é semelhantemente expresso por ambas populações, temos um perfil semelhante de resposta entre os grupos imunizados com $\alpha$ DEC-NS1 ou 33D1-NS1, indicando que ambas as populações de DCs são capazes de realizar apresentação cruzada. Este dado é bastante interessante porque até o presente momento, não há na literatura nenhum dado que mostre conclusivamente que as DCs DCIR2 $^{+}$sejam capazes de fazer apresentação cruzada. A ausência desta evidência pode se dever ao fato de que o anticorpo 33D1 fusionado a proteínas de interesse foi sempre utilizado na presença de Poly I:C e/ou Poly I:C+anti-CD40 (Dudziak et al., 2007; Soares et al., 2007) ou aos sistemas utilizados nestes estudos.

O nosso resultado mais surpreendente, entretanto, foi o que obtivemos com as imunizações na presença de MDP. O MDP é um agonista dos receptores NOD2 e Nalp3, que dão início a uma via de sinalização capaz de ativar respostas mediadas por inflamossomos e dependentes de IL-1 $\beta$ (Martinon et al., 2009). Outros estudos envolvendo direcionamento de antígenos para células dendríticas e comparação entre diversos agonistas demonstraram que a maior eficiência de Poly I:C em estimular respostas celulares quando antígenos são direcionados para a população de $\mathrm{DCs} \mathrm{CD} 8{ }^{+} \mathrm{CD} 205^{+}$está justamente no fato deste agonista ser capaz de estimular receptores do tipo NLR - no caso, MDA5 - e com isso induzir a expressão de níveis séricos elevados de Interferons tipo I liberados por DCs, células epiteliais e monócitos, que auxiliam na maturação eficiente das DCs, e estimulam sua migração para órgãos linfóides (Longhi et al., 2009). Outros estudos preliminares ainda não publicados do mesmo grupo apontam que a indução da expressão e liberação de Interferons tipo I pelas próprias DCs, em uma via de sinalização autócrina, já seria suficiente para gerar estes efeitos (Trumpfheller et al., 2011).

No entanto, quando utilizamos MDP como agonista - sem um estímulo concomitante via TLR, como é o caso para Poly I:C - não observamos indução de respostas celulares apreciáveis quando NS1 foi direcionada para a população de $\mathrm{DCs} \operatorname{CD} 8^{+} \mathrm{CD} 205^{+}$. Quando o direcionamento teve por alvo a população de DCs CD8 ${ }^{-}$DCIR2 $^{+}$observamos uma baixa resposta celular específica.

Conjuntamente, os resultados destes experimentos confirmam dados prévios sobre a eficiência das $\mathrm{DCs} \mathrm{CD}^{+} \mathrm{CD} 205^{+}$apresentarem antígenos, através do fenômeno de crosspriming, para linfócitos $\mathrm{T} \mathrm{CD}^{+}$. Diferente de outros estudos, contudo, observamos este fenômeno ocorrendo em outras populações de DCs, com eficiência comparável às $\mathrm{CD}^{+} \mathrm{CD} 205^{+}$, quando a imunização foi realizada na presença de outros agonistas, como o CpG. 
Também avaliamos nestes experimentos a resposta humoral suscitada por nossas imunizações, através da detecção dos títulos de anticorpos IgG anti-NS1. Observamos de uma forma geral títulos mais altos nos animais imunizados na presença de Poly I:C, títulos intermediários quando imunizamos na presença de $\mathrm{CpG}$ e títulos menos pronunciados nos animais imunizados na presença de MDP. Mais interessante, entretanto, foi nossa observação de que os animais imunizados com o anticorpo $\alpha$ DEC-NS1 apresentaram títulos mais baixos de anticorpos do que aqueles imunizados com 33D1-NS1. Como comprovamos que os epítopos de NS1 reconhecidos por Linfócitos B são quase exclusivamente conformacionais, esta observação pode estar intimamente relacionada com o tempo que a proteína NS1 se encontra intacta e, portanto, não internalizada e processada, em cada um destes sistemas. Assim, podemos especular que o direcionamento via $\alpha$ DEC-NS1 induza a internalização e o processamento da proteína NS1 mais rapidamente do que o direcionamento via 33D1-NS1. Outros estudos preliminares realizados por nosso grupo, contudo, parecem mostrar que não é este o caso, quando os anticorpos $\alpha$ DEC-NS1 e 33D1-NS1 encontram as respectivas populações de DCs para os quais são específicos. Portanto, poderíamos ainda especular que o anticorpo 33D1-NS1 não encontre seu receptor específico tão prontamente quanto $\alpha \mathrm{DEC}$ NS1. Mais estudos se fazem necessários para avaliar esta questão.

Além destes ensaios para a avaliação das respostas imunes celulares e humorais, dado nosso interesse em desenvolver novas estratégias vacinais com possibilidade de utilização em humanos, decidimos testar nossos protocolos de imunização contra um desafio envolvendo a injeção intra-cerebral de uma dose (LD50) de DENV2, capaz de suscitar uma infecção aguda. Esta infecção leva a um quadro de sintomatologias diversas como paralisia das patas traseiras e dianteiras, recrudescimento da coluna, podendo evoluir para a morte do camundongo, muitas vezes por inanição. Contudo, para estes experimentos, decidimos utilizar um protocolo de imunização distinto que consiste na administração de duas doses de $5 \mu \mathrm{g}$ dos diferentes anticorpos quiméricos, distantes 28 dias entre si. O desafio ocorreu sempre 15 dias após a segunda dose de nossa formulação vacinal. As imunizações ocorreram na presença do agonista Poly I:C.

Interessantemente, a imunização com o anticorpo $\alpha$ DEC-NS1 foi capaz de induzir proteção ao desafio nos animais imunizados (FIGURA 11), além de impedir o desenvolvimento dos quadros de infecção mais graves na maior parte dos camundongos imunizados (FIGURA 12). Este dado nos deixou bastante otimistas, mas analisado isoladamente nos informava pouco acerca dos mecanismos de proteção. No mesmo 
experimento, contudo, os animais imunizados com 33D1-NS1 não apresentaram qualquer melhora na sobrevivência ao desafio quando comparados aos animais dos grupos controle. Estes animais, embora não apresentem nenhum indício de resposta celular específica contra NS1, possuem títulos de anticorpos anti-NS1 muito semelhantes aos apresentados pelos animais imunizados com $\alpha$ DEC-NS1. Embora não tenhamos uma análise qualitativa que nos permita inferir que tais títulos de anticorpos sejam específicos para os mesmos epitopos, estes dados, junto a uma análise do local da infecção - o cérebro - pouco propícia à ação de anticorpos, nos fizeram supor que a proteção estaria sendo mediada principalmente por eventos de imunidade celular específica, dependentes de linfócitos $\mathrm{T}$.

Por esta razão, resolvemos repetir o experimento anterior, incluindo grupos imunizados com $\alpha$ DEC-NS1 e que, no dia anterior ao desafio, seriam depletados de Linfócitos $\mathrm{T} \mathrm{CD}^{+}$ou $\mathrm{CD}^{+}$, através da injeção retro-ocular de anticorpos $\alpha \mathrm{CD} 4$ ou $\alpha \mathrm{CD} 8$, respectivamente. Com este experimento, pretendíamos avaliar a importância de cada uma destas populações na proteção conferida por nosso protocolo de imunização.

De fato, conforme supúnhamos, a depleção da população de linfócitos T $\mathrm{CD}^{+}$ reverteu o quadro de sobrevivência dos animais imunizados com $\alpha$ DEC-NS1. Contudo, de forma bastante interessante e surpreendente, a depleção deste grupo celular não impediu uma proteção contra os sintomas da infecção aguda de forma tão intensa como a depleção da população de linfócitos $\mathrm{T} \mathrm{CD}^{+}$. A depleção desta segunda população não só reverteu o quadro de sobrevivência observado (FIGURA 13), como reverteu completamente a proteção observada em relação à morbidade causada pelo desafio (FIGURA 14). Este experimento nos dá amplo apoio na suposição de que nosso protocolo de vacinação esteja induzindo respostas celulares mediadas tanto por linfócitos $\mathrm{T} \mathrm{CD}^{+}$quanto por linfócitos $\mathrm{T} \mathrm{CD} 4^{+}$, muito embora nosso sistema de reestimulação não nos permita visualizar a indução destes últimos eventos, devido à falta de peptídeos especificamente reconhecidos por células $\mathrm{T} C D 4^{+}$que possamos utilizar nestes ensaios. Além disso, este ensaio nos permite concluir que uma vacina eficiente contra DENV poderia ser baseada ao menos parcialmente em respostas protetoras mediadas por linfócitos $\mathrm{T}$.

Apesar das evidências sobre a presença de respostas celulares mediadas por linfócitos $\mathrm{T} \mathrm{CD}^{+}$específicos contra NS1, nosso sistema não nos permitiu cumprir um outro objetivo de nosso projeto, que seria a comparação das respostas mediadas por linfócitos $\mathrm{T} \mathrm{CD}^{+}$ específicas contra NS1 quanto esta proteína fosse direcionada para as populações de DCs $\mathrm{CD}^{+}{ }^{+} \mathrm{DEC}_{20} 5^{+}$ou $\mathrm{CD}^{-} \mathrm{DCIR}^{+}$na presença de diferentes agonistas. Por este motivo, decidimos avaliar estas diferenças em outro modelo, direcionando o peptídeo PADRE, 
extremamente imunogênico e especificamente reconhecido pela população de linfócitos $\mathrm{T}$ $\mathrm{CD}^{+}$, para estas duas populações de DCs através de anticorpos monoclonais $\alpha \mathrm{DEC}-\mathrm{MSP} 1_{19^{-}}$ PADRE ou 33D1-MSP1 $1_{19}$-PADRE em duas doses de $5 \mu \mathrm{g}$ na presença de Poly I:C ou CpG.

Embora nosso interesse não estivesse centrado na proteína $\mathrm{MSP}_{19}$, os títulos de anticorpos gerados contra esta proteína foram um bom indicador, que já havia sido descrito por nosso grupo, para verificar a eficiência de nossa imunização. Também nesse sistema verificamos títulos mais expressivos de anticorpos induzidos por Poly I:C (FIGURA 15).

Contudo, graças ao modelo utilizando PADRE, pudemos realizar diversos experimentos para avaliar diferentes aspectos das respostas de linfócitos T CD4 ${ }^{+}$específicos para este peptídeo induzidas pelo direcionamento para as duas principais populações de DCs do baço de camundongos.

Quando avaliamos o número de células produtoras de IFN- $\gamma$, observamos que quando direcionamos antígenos na presença de Poly I:C, também a resposta de linfócitos T CD4 ${ }^{+}$só parece ser induzida eficientemente quando direcionada para a população de DCs que apresenta receptores para este agonista, as $\mathrm{CD}^{+} \mathrm{DEC} 205^{+}$. O direcionamento para as DCs CD8`DCIR2 ${ }^{+}$também promoveu um aumento do número de células produtoras desta citocina, porém mais discreto (FIGURA 16.A). Diferente do observado para NS1, contudo, o direcionamento de PADRE na presença de CpG não foi capaz de induzir qualquer tipo de resposta observável por esta metodologia, o que poderia indicar uma diferença significativa entre a indução de respostas por linfócitos T CD4 ${ }^{+}$e CD8 ${ }^{+}$(FIGURA 16.B).

Surpreendentemente, ao analisarmos a proliferação celular dos linfócitos T CD4 ${ }^{+}$ específicos para o PADRE, fomos capazes de detectar altos níveis de proliferação tanto no direcionamento na presença de Poly I:C quanto na de CpG. Contudo estas respostas foram bastante distintas, sendo que na presença de Poly I:C continuamos observando resposta significativas somente quando o antígeno é direcionado para a população de DCs $\mathrm{CD}^{+}{ }^{+} \mathrm{DEC}_{205^{+}}$(FIGURA 17.A), e na presença de $\mathrm{CpG}$, embora a proliferação seja menos pronunciada que aquela induzida na presença de Poly I:C, observamos níveis semelhantes de proliferação quando o antígeno é direcionado para qualquer das duas populações de DCs testadas (FIGURA 17.B).

Este dado, contudo, pode ter pouca significância, uma vez que analisando o perfil de citocinas expresso por células dos mesmos camundongos, não observamos quantidades significativas de quaisquer das citocinas analisadas - IFN- $\gamma$ (FIGURA 18.B); IL-2 (FIGURA 19.B); ou TNF- $\alpha$ (FIGURA 20.B), quando o antígeno foi direcionado para qualquer uma das 
populações de células dendríticas analisadas. Outros autores observaram um tipo de resposta semelhante, que envolvia proliferação de uma população de linfócitos sem uma resposta inflamatória concomitante, e provaram que, em seu sistema, o fenômeno na verdade estava relacionado com o posterior desaparecimento deste grupo de células e tolerização ao antígeno (Hawiger et al., 2001). Embora não possamos afirmar tal coisa, podemos especular que algo semelhante poderia estar acontecendo quando direcionamos PADRE na presença de CpG. No entanto, dado o nosso protocolo de imunização baseado em duas doses de antígeno, esta conclusão é menos provável.

Por outro lado, o direcionamento para as DCs $\mathrm{CD} 8^{+} \mathrm{DEC} 205^{+}$na presença de Poly I:C mostrou-se capaz de induzir níveis apreciáveis de todas as três citocinas analisadas (FIGURAS 18.A; 19.A; e 20.A), conforme o esperado, tendo em vista outros experimentos nossos e de outros grupos que atualmente trabalham com direcionamento de antígenos para células dendríticas.

Desta forma, podemos especular que, de fato, o direcionamento na presença de Poly I:C seja mais eficiente que qualquer outro protocolo que tenha sido testado até o presente momento (Longhi et al., 2009), embora ainda precisemos averiguar se os indicadores analisados se traduzem em correlatos e proteção eficazes. 


\section{CONCLUSÕES}


Nossos resultados nos permitem concluir que:

- A produção dos anticorpos quiméricos em fusão com a proteína NS1 foi realizada com sucesso. Os anticorpos se mantiveram íntegros e suas capacidades de ligação especificas aos receptores DEC205 e DCIR2 foram preservadas.

- A imunização com uma única dose do anticorpo $\alpha$ DEC-NS1 na presença de poly I:C é capaz de induzir uma resposta celular mediada por Linfócitos $\mathrm{T} C \mathrm{C} 8^{+}$. Na presença de $\mathrm{CpG}$, uma única dose de $\alpha$ DEC-NS1 ou 33D1-NS1 é igualmente eficaz na indução deste tipo de resposta. Quando o agonista utilizado é o MDP, somente a imunização com 33D1-NS1 induziu respostas celulares mediadas por Linfócitos T $\mathrm{CD} 8^{+}$.

- A imunização com uma única dose de qualquer um dos anticorpos na presença de qualquer dos três agonistas analisados foi capaz de induzir respostas humorais, exceto quando utilizamos $\alpha$ DEC-NS1 na presença de MDP, que não induziu qualquer resposta humoral detectável.

- A imunização com duas doses de anticorpo aDEC-NS1 ou 33D1-NS1 na presença de Poly I:C foi capaz de induzir títulos elevados de anticorpos anti-NS1.

- A imunização com duas doses de anticorpo só foi capaz de induzir proteção dos animais a um desafio experimental por DENV2 quando a proteína NS1 foi direcionada para a população de $\mathrm{DCs} \mathrm{CD}^{+} \mathrm{DEC} 205^{+}$. Esta proteção não se manteve quando depletamos a população de Linfócitos T $\mathrm{CD} 4^{+}$ou $\mathrm{CD}^{+}$dos animais imunizados com $\alpha \mathrm{DEC}-\mathrm{NS} 1$.

- A imunização com duas doses de $\alpha$ DEC-MSP $1_{19}$-PADRE ou 33D1-MSP $1_{19}$-PADRE induziu forte resposta humoral anti-MSP1 $1_{19}$, independente do agonista utilizado ser Poly I:C ou CpG.

- A imunização com duas doses de $\alpha$ DEC-MSP1 ${ }_{19}$-PADRE na presença de poly I:C induziu as mais robustas respostas celulares mediadas por Linfócitos $\mathrm{T} \mathrm{CD}^{+}$, tanto quando avaliamos a proliferação destas células quanto a produção de citocinas por elas.

- A imunização com duas doses de $\alpha$ DEC-MSP $1_{19}$-PADRE ou 33D1-MSP1 $1_{19}$-PADRE na presença de $\mathrm{CpG}$ induziu respostas celulares mediadas por Linfócitos $\mathrm{T} \mathrm{CD}^{+}$bem menos pronunciadas que as observadas quando utilizamos Poly I:C, sendo que observamos níveis similares de proliferação celular destas células quando comparamos o direcionamento para os dois tipos distintos de DCs. Não observamos produção de nenhuma citocina em níveis significativamente maiores que os controles. 


\section{REFERÊNCIAS}


Ahlborg $\mathrm{N}$, et al. Protective immune responses to the 42-kilodalton $(\mathrm{kDa})$ region of Plasmodium yoelii merozoite surface protein 1 are induced by the C-terminal 19-kDa region but not by the adjacent 33-kDa region. Infect Immun. 2002;70(2):820-825.

Aida Y, Pabst MJ. Removal of endotoxin from protein solutions by phase separation using Triton X-114. J Immunol Methods. 1990;132(2):191-195.

Albert ML, Sauter B, Bhardwaj N. Dendritic cells acquire antigen from apoptotic cells and induce class I-restricted CTLs. Nature. 1998;392:86-89.

Alexander J, et al. Development of high potency universal DR-restricted helper epitopes by modification of high affinity DR-blocking peptides. Immunity. 1994;1(9):751-761.

Allan RS, et al. Epidermal viral immunity induced by CD8alpha + dendritic cells but not by Langerhans cells.Science. 2003;301:1925-1928.

Allan RS, et al. Migratory dendritic cells transfer antigen to a lymph node-resident dendritic cell population for efficient CTL priming. Immunity. 2006;25:153-162.

Amorim $\mathrm{JH}$, et al. Refolded dengue virus type 2 NS1 protein expressed in Escherichia coli preserves structural and immunological properties of the native protein. J Virol Meth. 2010;167:186-192.

Ashour J, et al. NS5 of dengue virus mediates STAT2 binding and degradation. J Virol. 2009;83:5408-5418.

Asselin-Paturel C, et al. Mouse type I IFN-producing cells are immature APCs with plasmacytoid morphology. Nat Immunol. 2001;2:1144-1150.

Bairs JK. Host age as a determinant of naturally acquired immunity to Plasmodium falciparum. Parasitol Today. 1995;11:105-111.

Barbosa IM. Direcionando as proteínas MSP-1 ${ }_{19}$ de Plasmodium vivax e Plasmodium yoelii para células dendríticas in vivo: análise das respostas imunes celular e humoral. 2011. 116f. Dissertação (Mestrado em Biologia da Interação Patógeno-Hospedeiro) - Instituto de Ciências Biomédicas, Universidade de São Paulo, São Paulo. 2011.

Beaumier CM, Rothman AL. Cross-reactive memory CD4+ T cells alter the CD8+ T-cell response to heterologous secondary dengue virus infections in mice in a sequence-specific manner. Viral Immunol. 2009;22:215-219.

Belz GT, et al. The CD8alpha(+) dendritic cell is responsible for inducing peripheral selftolerance to tissue-associated antigens. J Exp Med. 2002;196:1099-1104.

Bender A, et al. Improved methods for the generation of dendritic cells from nonproliferating progenitors in human blood. J Immunol Methods. 1996;196:121-135.

De acordo com:

Internatinal Committee of Medical Journal Editors. Uniform requirements for manuscripts submitted to

Biomedical Journal: sample references. Available from: http://www.icmje.org [2007 May 22]. 
Benko S, Philpott DJ, Girardin S. E. The microbial and danger signals that activate Nod-like receptors. Cytokine. 2008;43 (3):368-373.

Blacklay S, et al. Primary human splenic macrophages, but not $\mathrm{T}$ or B cells, are the principal target cells for dengue virus infection in vitro. J Virol. 2007:81:13325-13334.

Bogunovic $\mathrm{M}$, et al. Origin of the lamina propria dendritic cell network. Immunity. 2009;31:513-525.

Bonasio R, et al. Clonal deletion of thymocytes by circulating dendritic cells homing to the thymus. Nat Immunol. 2006;7:1092-1100.

Bonifaz L, et al. In vivo targeting of antigens to maturing dendritic cells via the DEC-205 receptor improves T cell vaccination. J Exp Med. 2004;199:815-824.

Bonifaz L, et al. Efficient targeting of protein antigen to the dendritic cell receptor DEC-205 in the steady state leads to antigen presentation on major histocompatibility complex class I products and peripheral CD8+ T cell tolerance. J Exp Med. 2002;196:1627-1638.

Boonak K, et al. Role of dendritic cells in antibody-dependent enhancement of dengue virus infection. J Virol. 2008;82:3939-3951.

Boscardin SB, et al. Antigen targeting to dendritic cells elicits long-lived $\mathrm{T}$ cell help for antibody responses. J Exp Med. 2006;203(3):599-606.

Boulanger D, et al. Vaccination of patas monkeys experimentally infected with Schistosoma haematobium using a recombinant glutathione S-transferase cloned from S. mansoni. Parasite Immunol. 1995;17(7):361-369.

Bozzacco L, et al. DEC-205 receptor on dendritic cells mediates presentation of HIV gag protein to CD8+ T cells in a spectrum of human MHC I haplotypes. Proc Natl Acad Sci USA. 2007;104:1289-1294.

Brocker T, Riedinger M, Karjalainen $\mathrm{K}$. Targeted expression of major histocompatibility complex (MHC) class II molecules demonstrates that dendritic cells can induce negative but not positive selection of thymocytes in vivo. J Exp Med. 1997;185:541-550.

Bursch LS, et al. Identification of a novel population of Langerin+ dendritic cells. J Exp Med. 2007;204:3147-3156.

Chen MC, et al. Deletion of the C-terminal region of dengue virus nonstructural protein 1 (NS1) abolishes anti-NS1-mediated platelet dysfunction and bleeding tendency. J Immunol. 2009;183(3):1797-1803.

Cheng HJ, et al. Anti-dengue virus nonstructural protein 1 antibodies recognize protein disulfide isomerase on platelets and inhibit platelet aggregation. Mol Immunol. 2009;47:398406. 
Churdboonchart V, et al. Antibodies against dengue viral proteins in primary and secondary dengue hemorrhagic fever. Am J Trop Med Hyg. 1991;44:481-493.

Costa SM, et al. DNA vaccines against dengue virus based on the ns1 gene: the influence of different signal sequences on the protein expression and its correlation to the immune response elicited in mice. Virology. 2007;358(2):413-423.

Costa SM, Freire MS, Alves AM. DNA vaccine against the non-structural 1 protein (NS1) of dengue 2 virus. Vaccine. 2006;24:4562-4564.

Crill WD, et al. Humoral immune responses of dengue fever patients using epitope-specific serotype-2 virus-like particle antigens. PLoS One. 2009;4:e4991.

D'Amico A, Wu L. The Early Progenitors of Mouse Dendritic Cells and Plasmacytoid Predendritic Cells Are within the Bone Marrow Hemopoietic Precursors Expressing Flt3. J Exp Med. 2003;198:293-303.

De Smedt T, et al. Regulation of dendritic cell numbers and maturation by lipopolysaccharide in vivo. J Exp Med. 1996;184:1413-1424.

del Portillo HA, et al. Primary structure of the merozoite surface antigen 1 of Plasmodium vivax reveals sequences conserved between different Plasmodium species. Proc Natl Acad Sci USA. 1991;88(9):4030-4034.

Den Haan JM, Lehar SM, Bevan MJ. CD8(+) but not CD8(-) dendritic cells cross-prime cytotoxic T cells in vivo. J Exp Med. 2000;192(12):1685-1696.

Dudziak D, et al. Differential antigen processing by dendritic cell subsets in vivo. Science. 2007;315:107-111.

Dutta S, et al. Purification, characterization, and immunogenicity of a disulfide cross-linked Plasmodium vivax vaccine candidate antigen, merozoite surface protein 1 , expressed in Escherichia coli. Infect. Immun. 2001;69(9):5464-5470.

Edwards $\mathrm{BH}$, et al. Magnitude of functional CD8+ T-cell responses to the gag protein of human immunodeficiency virus type 1 correlates inversely with viral load in plasma. J Virol. 2002;76:2298-2305.

Edwards DA, et al. Toll-like receptor expression in murine DC subsets: lack of TLR7 expression by CD8 alpha+ DC correlates with unresponsiveness to imidazoquinolines. Eur J Immunol. 2003;33:827-833.

Ellis RD, et al. A Phase 1 study of the blood-stage malaria vaccine candidate AMA1C1/Alhydrogel with CPG 7909, using two different formulations and dosing intervals. Vaccine. 2009;27(31):4104-4109.

Falgout $\mathrm{B}$, et al. Immunization of mice with recombinant vaccinia virus expressing authentic dengue virus nonstructural protein NS1 protects against lethal dengue virus encephalitis. $\mathrm{J}$ Virol. 1990;64:4356-4363. 
Falgout B, Chanock R, Lai CJ. Proper processing of dengue virus nonstructural glycoprotein NS1 requires the N-terminal hydrophobic signal sequence and the downstream nonstructural protein NS2a. J Virol. 1989;63:1852-1860.

Figdor CG, van Kooyk Y, Adema GJ. Proper processing of dengue virus nonstructural glycoprotein NS1 requires the N-terminal hydrophobic signal sequence and the downstream nonstructural protein NS2a. Nat Rev Immunol. 2002;2(2):77-84.

Flamand M, et al. Dengue virus type 1 nonstructural glycoprotein NS1 is secreted from mammalian cells as a soluble hexamer in a glycosylation-dependent fashion. J Virol. 1999;73:6104-6110.

Flornes LM, et al. Identification of lectin-like receptors expressed by antigen presenting cells and neutrophils and their mapping to a novel gene complex. Immunogenetics. 2004;56:506517.

Fogg DK, et al. A clonogenic bone marrow progenitor specific for macrophages and dendritic cells. Science. 2006;311:83-87.

Fried JR, et al. Serotype-specific differences in the risk of dengue hemorrhagic fever: an analysis of data collected in Bangkok, Thailand from 1994 to 2006. PLoS Negl Trop Dis. 2010;4:e617.

Gao G, et al. Adenovirus-based vaccines generate cytotoxic $\mathrm{T}$ lymphocytes to epitopes of NS1 from dengue virus that are present in all major serotypes. Hum Gene Ther. 2008;19(9):927-936.

Geijtenbeek TB, et al. Identification of DC-SIGN, a novel dendritic cell-specific ICAM-3 receptor that supports primary immune responses. Cell. 2000;100:575-585.

Gil L, et al. The cellular immune response plays an important role in protecting against dengue virus in the mouse encephalitis model. Viral Immunol. 2009;22:23-30.

Gil L, et al. Recombinant nucleocapsid-like particles from dengue-2 virus induce protective CD4+ and CD8+ cells against viral encephalitis in mice. Int mmunol. 2009;21:1175-1183.

Ginhoux F, et al. Langerhans cells arise from monocytes in vivo. Nat Immunol. 2006;7:265273.

Ginhoux F, et al. The origin and development of nonlymphoid tissue CD103+ DCs. J Exp Med. 2009;206:3115-3130.

Greenwood BM, et al. Malaria: progress, perils, and prospects for eradication. J Clin Invest. 2008;118(4):1266-1276.

Gubler DJ. Dengue and Dengue Hemorrhagic Fever. Clin Microbiol Rev. 1998;11:480-496.

Guy B, et al. Cell-mediated immunity induced by chimeric tetravalent dengue vaccine in naive or flavivirus-primed subjects. Vaccine. 2008;26:5712-5721. 
Guy B, et al. Evaluation of interferences between dengue vaccine serotypes in a monkey model. Am J Trop Med Hyg. 2009;80:302-311.

Guzmán CA, Kouri G. Dengue: an update. Lancet Infect Dis. 2002;2:33-42.

Halperin SA, et al. A phase I study of the safety and immunogenicity of recombinant hepatitis B surface antigen co-administered with an immunostimulatory phosphorothioate oligonucleotide adjuvant. Vaccine. 2003;21:2461-2467.

Halstead SB, et al. Dengue hemorrhagic fever in infants: research opportunities ignored. Emerg Infect. 2002;8:1474-1479.

Han HJ, et al. Epidermal growth factor-like motifs 1 and 2 of Plasmodium vivax merozoite surface protein 1 are critical domains in erythrocyte invasion. Biochem. Biophys. Res. Commun. 2004;320(2):563-570.

Hawiger D, et al. Dendritic cells induce peripheral T cell unresponsiveness under steady state conditions in vivo. J Exp Med. 2001;194(6):769-779.

Hemmi H, et al. A Toll-like receptor recognizes bacterial DNA. Nature. 2000;408:740-745.

Henchal EA, Henchal LS, Schlesinger JJ. Synergistic interactions of anti-NS1 monoclonal antibodies protect passively immunized mice from lethal challenge with dengue 2 virus. J Gen Virol. 1988;69:2101-2107.

Hermansson A, et al. Inhibition of $\mathrm{T}$ cell response to native low-density lipoprotein reduces atherosclerosis. J Exp Med. 2010;207:1081-1093.

Holder AA, Blackman MJ. What is the function of MSP-I on the malaria merozoite? Parasitol Today. 1994;10(5):182-184.

Holmes EC, Twiddy SS. The origin, emergence and evolutionary genetics of dengue virus. Infect Genet Evol. 2003;3:19-28.

Hoshino K, et al. Cutting edge: Toll-like receptor 4 (TLR4)-deficient mice are hyporesponsive to lipopolysaccharide: evidence for TLR4 as the Lps gene product. J Immunol. 1999;162:3749-3752.

Idoyaga $\mathrm{J}$, et al. Antibody to Langerin/CD207 localizes large numbers of CD8alpha+ dendritic cells to the marginal zone of mouse spleen. Proc Natl Acad Sci USA. 2009;106:1524-1529.

Idoyaga J, et al. Comparable T helper 1 (Th1) and CD8 T-cell immunity by targeting HIV gag p24 to CD8 dendritic cells within antibodies to Langerin, DEC205, and Clec9A. Proc Natl Acad Sci USA. 2011;108:2384-2389. 
Imrie A, et al. Homology of complete genome sequences for dengue virus type-1, from dengue-fever- and dengue-haemorrhagic-fever-associated epidemics in Hawaii and French Polynesia. Ann Trop Med Parasitol. 2010;104:225-235.

Jacobs MG, et al. Dengue virus nonstructural protein 1 is expressed in a glycosylphosphatidylinositol-linked form that is capable of signal transduction. FASEB J. 2000;14:1603-1610.

Jakubzick C, et al. Lymph-migrating, tissue-derived dendritic cells are minor constituents within steady-state lymph nodes. J Exp Med. 2008;2839-2850.

Jessie $\mathrm{K}$, et al. Localization of dengue virus in naturally infected human tissues, by immunohistochemistry and in situ hybridization. J Infect Dis. 2004;189:1411-1418.

Jiang W, et al. The receptor DEC-205 expressed by dendritic cells and thymic epithelial cells is involved in antigen processing. Nature. 1995;375;151-155.

Jordan M, Schallhorn A., Wurm F.M. Transfecting mammalian cells: optimization of critical parameters affecting calcium-phosphate precipitate formation. Nucleic Acid Res. 1996;24:596-601.

Kabashima $\mathrm{K}$, et al. Intrinsic lymphotoxin-beta receptor requirement for homeostasis of lymphoid tissue dendritic cells. Immunity. 2005;22:439-450.

Kim JM, Rasmussen JP, Rudensky AY. Regulatory T cells prevent catastrophic autoimmunity throughout the lifespan of mice. Nat Immunol. 2007;8:191-197.

Kingston D, et al. The concerted action of GM-CSF and Flt3-ligand on in vivo dendritic cell homeostasis. Blood. 2009;114:835-843.

Kliks SC, et al. The concerted action of GM-CSF and Flt3-ligand on in vivo dendritic cell homeostasis. Am J Trop Med Hyg. 1988;38:411-419.

Klinman DM, et al. Immunotherapeutic applications of CpG-containing oligodeoxynucleotides. Drug News Perspect. 2000;13(5):289-296.

Klinman DM, et al. CpG oligonucleotides as adjuvants for vaccines targeting infectious diseases. Adv Drug Deliv Rev. 2009;61(3):248-255.

Kou Z, et al. Monocytes, but not $\mathrm{T}$ or $\mathrm{B}$ cells, are the principal target cells for dengue virus (DV) infection among human peripheral blood mononuclear cells. J Med Virol. 2008;80:134146. 
Kretschmer $\mathrm{K}$, et al. Inducing and expanding regulatory $\mathrm{T}$ cell populations by foreign antigen. Nat Immunol. 2005;6:1219-1227.

Kumagai Y, Takeuchi O, Akira S. Pathogen recognition by innate receptors. J Infect Chemother. 2008;14:86-92.

Kumar H, Kawai T, Akira S. Toll-like receptors and innate immunity. Biochem Biophys Res Commun. 2009;388:621-625.

Kyle JL, et al. Antibodies play a greater role than immune cells in heterologous protection against secondary dengue virus infection in a mouse model. Virology. 2008;380:296-303.

Kyle JL, Harris E. Global spread and persistence of dengue. Annu Rev Microbiol. 2008;62:71-92.

Lee MS, Kim YJ. Signaling pathways downstream of pattern-recognition receptors and their cross talk. Annu Rev Biochem. 2007;76:447-480.

Lemesre JL, et al. Protection against experimental visceral leishmaniasis infection in dogs immunized with purified excreted secreted antigens of Leishmania infantum promastigotes. Vaccine. 2005;23:2825-2840.

Lemaitre B, et al. The dorsoventral regulatory gene cassette spätzle/Toll/cactus controls the potent antifungal response in Drosophila adults. Cell. 1996;86:973-983.

Leng $\mathrm{CH}$, et al. A novel dengue vaccine candidate that induces cross-neutralizing antibodies and memory immunity Microbes Infect. 2009;11:288-295.

Lin CF, et al. Antibodies from dengue patient sera cross-react with endothelial cells and induce damage. J Med Virol. 2003;69:82-90.

Lindenbach BD, Rice CM. Fields Virology. Lippincott Williams and Wilkins, Philadelphia, pp. 991-1041.2001.

Liu YJ. Dendritic cell subsets and lineages, and their functions in innate and adaptive immunity. Cell. 2001;106:259-262.

Liu K, et al. Origin of dendritic cells in peripheral lymphoid organs of mice. Nat Immunol. 2007;8:578-583.

Liu K, et al. In vivo analysis of dendritic cell development and homeostasis. Science. 2009;324:392-397.

Liu K, et al. Immune tolerance after delivery of dying cells to dendritic cells in situ. J Exp Med. 2002;196:1091-1097.

Liu K, Nussenzweig MC. Origin and development of dendritic cells. Immunological Reviews. 2010;234:45-51. 
Longacre S, Mendis KN, David PH. Plasmodium vivax merozoite surface protein $1 \mathrm{C}$ terminal recombinant proteins in baculovirus. Mol Biochem Parasitol. 1994;64:191-205.

Longhi MP, et al. Dendritic cells require a systemic type I interferon response to mature and induce CD4+ Th1 immunity with poly IC as adjuvant. J Exp Med. 2009;206:1589-1602.

López-Bravo M, Ardavín C. In vivo induction of immune responses to pathogens by conventional dendritic cells. Immunity. 2008;29:343-351.

Luo X, et al. Dendritic cells with TGF-beta1 differentiate naive CD4+CD25- T cells into islet-protective Foxp3+ regulatory T cells. Proc Natl Acad Sci USA. 2007;104:2821-2826.

Mahnke K, et al. Induction of $\mathrm{CD} 4+/ \mathrm{CD} 25+$ regulatory $\mathrm{T}$ cells by targeting of antigens to immature dendritic cells. Blood. 2003;101:4862-4869.

Maldonado-Lopez R, et al. Cytokines regulate the capacity of CD8alpha(+) and CD8alpha(-) dendritic cells to prime Th1/Th2 cells in vivo. J Immunol. 2001;167:4345-4350.

Mangada MM, et al. Dengue-specific T cell responses in peripheral blood mononuclear cells obtained prior to secondary dengue virus infections in Thai schoolchildren. J Infect Dis. 2002;185:1697-1703.

Manz MG, et al. Dendritic cell potentials of early lymphoid and myeloid progenitors. Blood. 2001;97:3333-3341.

Maraskovsky E, et al. Dramatic increase in the numbers of functionally mature dendritic cells in Flt3 ligand-treated mice: multiple dendritic cell subpopulations identified. J Exp Med. 1996;184:1953-1962.

Martinon F, Mayor A, Tschopp J. The inflammasomes: guardians of the body. Annu Rev Immunol. 2009;27:229-265.

Mathew A, Rothman AL. Understanding the contribution of cellular immunity to dengue disease pathogenesis. Immunol Rev. 2008;225:300-313.

Medzhitov R, et al. A human homologue of the Drosophila Toll protein signals activation of adaptive immunity. Nature. 1997;388:394-397.

Metcalf D. Lineage commitment and maturation in hematopoietic cells: the case for extrinsic regulation. Blood. 1998;92:345-347.

Miller N. Recent progress in dengue vaccine research and development. Curr Opin Mol Ther. 2010;12:31-38.

Mongkolsapaya $\mathrm{J}$, et al. $\mathrm{T}$ cell responses in dengue hemorrhagic fever: are cross-reactive $\mathrm{T}$ cells suboptimal? J Immunol. 2006;176:3821-3829. 
Mongkolsapaya $\mathrm{J}$, et al. Original antigenic sin and apoptosis in the pathogenesis of dengue hemorrhagic fever. Nat Med. 2003;9:921-927.

Moreira LO, et al. Modulation of adaptive immunity by different adjuvant-antigen combinations in mice lacking Nod2. Vaccine. 2008;26:5808-5813.

Mosier DE. A requirement for two cell types for antibody formation in vitro. Science. 1967;158:1573-1575.

Mueller I, et al. Key gaps in the knowledge of Plasmodium vivax, a neglected human malaria parasite. Lancet Infect Dis. 2009;9:555-566.

Murphy BR, Whitehead SS. Immune response to dengue virus and prospects for a vaccine. Annu Rev Immunol. 2011;29:587-619.

Myint KS, et al. Cellular immune activation in children with acute dengue virus infections is modulated by apoptosis. J Infect Dis. 2006;194:600-607.

Naik SH, et al. Cutting edge: generation of splenic CD8+ and CD8- dendritic cell equivalents in Fms-like tyrosine kinase 3 ligand bone marrow cultures. J Immunol. 2005;174:6592-6597.

Naik SH, et al. Intrasplenic steady-state dendritic cell precursors that are distinct from monocytes. Nat Immunol. 2006; 7:663-671.

Nakano H, Yanagita M, Gunn MD. CD11c(+)B220(+)Gr-1(+) cells in mouse lymph nodes and spleen display characteristics of plasmacytoid dendritic cells. J Exp Med. 2001;194:11711178.

Nguyen TH, et al. Dengue Hemorrhagic Fever in Infants: A Study of Clinical and Cytokine Profiles. J Infect Dis. 2004;189:221-232.

Nussenzweig MC, et al. Dendritic cells are accessory cells for the development of antitrinitrophenyl cytotoxic T lymphocytes. J Exp Med. 1980;152:1070-1084.

O'keffe M, et al. Mouse plasmacytoid cells: long-lived cells, heterogeneous in surface phenotype and function, that differentiate into $\mathrm{CD} 8(+)$ dendritic cells only after microbial stimulus. J Exp Med. 2002;196:1307-1319.

O'keffe M, et al. Fms-like tyrosine kinase 3 ligand administration overcomes a genetically determined dendritic cell deficiency in NOD mice and protects against diabetes development. Int Immunol. 2005;17:307-314.

Ohl L, et al. CCR7 governs skin dendritic cell migration under inflammatory and steady-state conditions. Immunity. 2004;21:279-288.

Onai N, et al. Activation of the Flt3 signal transduction cascade rescues and enhances type I interferon-producing and dendritic cell development. J Exp Med. 2006;203:227-238. 
Onai $\mathrm{N}$, et al. Identification of clonogenic common Flt3+M-CSFR+ plasmacytoid and conventional dendritic cell progenitors in mouse bone marrow. Nat Immunol. 2007;8:12071216.

Palucka AK. Dengue virus and dendritic cells. Nat Med. 2000;6:748-749.

Poltorak A, et al. Defective LPS signaling in $\mathrm{C} 3 \mathrm{H} / \mathrm{HeJ}$ and $\mathrm{C} 57 \mathrm{BL} / 10 \mathrm{ScCr}$ mice: mutations in Tlr4 gene. Science. 1998;282:2085-2088.

Pryor MJ, Wright PJ. The effects of site-directed mutagenesis on the dimerization and secretion of the NS1 protein specified by dengue virus. Virology. 1993;194:769-780.

Qureshi ST, et al. Endotoxin-tolerant mice have mutations in Toll-like receptor 4 (Tlr4). J Exp Med. 1999;189:615-625.

Ramanathan MP, et al. Development of a novel DNA SynCon tetravalent dengue vaccine that elicits immune responses against four serotypes. Vaccine. 2009;27:6444-6453.

Ramirez AH, et al. Evaluation of dengue NS1 antigen detection tests with acute sera from patients infected with dengue virus in Venezuela. Diagn Microbiol Infect Dis. 2009;65:247253.

Randolph GJ, et al. Differentiation of monocytes into dendritic cells in a model of transendothelial trafficking. Science. 1998;282:480-483.

Randolph GJ, et al. Differentiation of phagocytic monocytes into lymph node dendritic cells in vivo. Immunity. 1999;11:753-761.

Rodriguez-Madoz JR, et al. Inhibition of the type I interferon response in human dendritic cells by dengue virus infection requires a catalytically active NS2B3 complex. J Virol. 2010a;84:9760-9774.

Rodriguez Madoz JR, et al. Dengue virus inhibits the production of type I interferon in primary human dendritic cells. J Virol. 2010b;84:4845-4850.

Rosa DS, et al. The pan HLA DR-binding epitope improves adjuvant-assisted immunization with a recombinant protein containing a malaria vaccine candidate. Immunol Lett. 2004;92:259-268.

Rosa DS, et al. Immunogenicity of a recombinant protein containing the Plasmodium vivax vaccine candidate MSP1(19) and two human CD4+ T-cell epitopes administered to nonhuman primates (Callithrix jacchus jacchus). Microbes and Infection. 2006;8:2130-2137.

Rothman AL, et al. Dengue Haemorrhagic Fever. In: Salluzzo J.F., Dodet B., editors. Factors in the emergence of arbovirus diseases. Paris, France: Elsevier; 1997.pp.109-116.

Rothman AL. T lymphocyte responses to heterologous secondary dengue virus infections. Ann NY Acad Sci. 2009;1171:e36-41. 
Rothman AL. Cellular immunology of sequential dengue virus infection and its role in disease pathogenesis. Curr Top Microbiol Immunol. 2010;338:83-98.

Sallusto F, Lanzavecchia A. Efficient presentation of soluble antigen by cultured human dendritic cells is maintained by granulocyte/macrophage colony-stimulating factor plus interleukin 4 and downregulated by tumor necrosis factor alpha. J Exp Med. 1994;152:11091118.

Schlecht G, et al. Murine plasmacytoid dendritic cells induce effector/memory CD8+ T-cell responses in vivo after viral stimulation. Blood. 2004;104:1808-1815.

Serbina NV, et al. TNF/iNOS-producing dendritic cells mediate innate immune defense against bacterial infection. Immunity. 2003;19:59-70.

Schmid A, et al. Instructive cytokine signals in dendritic cell lineage commitment. Immunological Reviews. 2010;234:32-44.

Shortman K, Liu YJ. Mouse and human dendritic cell subtypes. Nat Rev Immunol. 2002;2:151-161.

Soares $\mathrm{H}$, et al. A subset of dendritic cells induces CD4+ T cells to produce IFN-gamma by an IL-12-independent but CD70-dependent mechanism in vivo. J Exp Med. 2007;204:10951106.

Soares IS, Rodrigues MM. Immunogenic properties of the Plasmodium vivax vaccine candidate MSP1(19) expressed as a secreted non-glycosylated polypeptide from Pichia pastoris. Parasitology. 2002;124:237-246.

Sprent J. Antigen-presenting cells. Professionals and amateurs. Curr Biol. 1995;5:1095-1097.

Srivastava AK, et al. Mice immunized with a dengue type 2 virus E and NS1 fusion protein made in Escherichia coli are protected against lethal dengue virus infection. Vaccine. $1995 ; 13: 1251-1258$.

Stahl-Hennig C, et al. Synthetic double-stranded RNAs are adjuvants for the induction of T helper 1 and humoral immune responses to human papillomavirus in rhesus macaques. PLoS Pathog. 2009;5:e1000373.

Steinbrink K, et al. Myeloid dendritic cell: From sentinel of immunity to key player of peripheral tolerance? Hum Immunol. 2009;70:289-293.

Steinman RM, Cohn ZA. Identification of a novel cell type in peripheral lymphoid organs of mice. I. Morphology, quantitation, tissue distribution. J Exp Med. 1973;137:1142-1162.

Steinman RM, Cohn ZA. Identification of a novel cell type in peripheral lymphoid organs of mice. II. Functional properties in vitro. J Exp Med. 1974;139:380-397. 
Steinman RM, Lustig DS, Cohn ZA. Identification of a novel cell type in peripheral lymphoid organs of mice. 3. Functional properties in vivo. J Exp Med. 1974;139:1431-1445.

Steinman RM, Witmer MD. Lymphoid dendritic cells are potent stimulators of the primary mixed leukocyte reaction in mice. Proc Natl Acad Sci USA. 1978;75:5132-5136.

Steinman RM, Hawiger D, Nussenzweig MC. Tolerogenic dendritic cells. Annu Rev Immunol. 2003;21:685-711.

Suzuki R, Winkelmann ER, Mason PW. Construction and characterization of a single-cycle chimeric flavivirus vaccine candidate that protects mice against lethal challenge with dengue virus type 2. J Virol. 2009;83:1870-1880.

Takeuchi O, et al. Differential roles of TLR2 and TLR4 in recognition of gram-negative and gram-positive bacterial cell wall components. Immunity. 1999;11:443-451.

Tan GK, Alonso S. Pathogenesis and prevention of dengue virus infection: state-of-the-art. Curr Opin Infect Dis. 2009;22:302-308.

Tarbell KV, et al. CD25+ CD4+ T cells, expanded with dendritic cells presenting a single autoantigenic peptide, suppress autoimmune diabetes. J Exp Med. 2004;199:1467-1477.

Thomas SJ, Endy TP. Critical issues in dengue vaccine development. Curr Op Infect Dis. $2011 ; 24: 442-450$.

Thomas SJ, Hombach J, Barrett A. Scientific consultation on cell mediated immunity (CMI) in dengue and dengue vaccine development. Vaccine. 2009;27:355-368.

Timofeev AV, Butenko VM, Stephenson JR. Genetic vaccination of mice with plasmids encoding the NS1 non-structural protein from tick-borne encephalitis virus and dengue 2 virus. Virus Genes. 2004;28:85-97.

Traver D, et al. Development of CD8alpha-positive dendritic cells from a common myeloid progenitor. Science. 2000;290:2152-2154.

Trumpfheller C, et al. The microbial mimic poly IC induces durable and protective CD4+ T cell immunity together with a dendritic cell targeted vaccine. Proc Natl Acad Sci. 2008;105:2574-2579.

Trumpfheller $\mathrm{C}$, et al. Intensified and protective CD4+ T cell immunity in mice with antidendritic cell HIV gag fusion antibody vaccine. J Exp Med. 2006;203:607-617.

Trumpfheller C, et al. Dendritic cell-targeted protein vaccines: a novel approach to induce Tcell immunity. J Int Med. 2012;doi:10.1111/j.1365-2796.2011.02496.x 
Twiddy SS, Holmes EC, Rambaut A. Inferring the rate and time-scale of dengue virus evolution. Mol Biol Evol. 2003;20:122-129.

Tzelepis F, et al. Distinct kinetics of effector CD8+ cytotoxic T cells after infection with Trypanosoma cruzi in naive or vaccinated mice. Infect Immun. 2006;74:2477-2481.

Ubol S, et al. Mechanisms of immune evasion induced by a complex of dengue virus and preexisting enhancing antibodies. J Infect Dis. 2010;201:923-935.

Valdes K, et al. Human Dengue antibodies against structural and nonstructural proteins. Clin Diagn Lab Immunol. 2000;7:856-857.

Varol $\mathrm{C}$, et al. Intestinal lamina propria dendritic cell subsets have different origin and functions. Immunity. 2009;31:502-512.

Villadangos JA, Schnorrer P. Intrinsic and cooperative antigen-presenting functions of dendritic-cell subsets in vivo. Nat Rev Immunol. 2007;7:543-555.

Villadangos JA, Young L. Antigen-presentation properties of plasmacytoid dendritic cells. Immunity. 2008;29:352-361.

Vremec D, et al. The influence of granulocyte/macrophage colony-stimulating factor on dendritic cell levels in mouse lymphoid organs. Eur J Immunol. 1997;27:40-44.

Vremec D, et al. CD4 and CD8 expression by dendritic cell subtypes in mouse thymus and spleen. J Immunol. 2000;164:2978-2986.

Wahala WM, et al. Dengue virus neutralization by human immune sera: role of envelope protein domain III-reactive antibody. Virology. 2009:392:103-113.

WHO. Dengue Haemorrhagic Fever: Diagnosis, Treatment, Prevention and Control. 1997; Genebra, Switzerland.

WHO. Impact of Dengue. 2010; Genebra, Switzerland.

Wilder-Smith A, et al. Update on dengue: epidemiology, virus evolution, antiviral drugs, and vaccine development. Curr Infect Dis Rep. 2010;12:157-164.

Winkler G, et al. Newly synthesized dengue-2 virus nonstructural protein NS1 is a soluble protein but becomes partially hydrophobic and membrane-associated after dimerization. Virology. 1989;171:302-305.

Witmer-Pack MD, et al. Identification of macrophages and dendritic cells in the osteopetrotic (op/op) mouse. J Cell Sci. 1993;104:1021-1029.

Wu SF, et al. Evaluation of protective efficacy and immune mechanisms of using a nonstructural protein NS1 in DNA vaccine against dengue 2 virus in mice.Vaccine. 2003;21:3919-3929. 
Yamazaki S, et al. CD8+ CD205+ splenic dendritic cells are specialized to induce Foxp3+ regulatory T cells. J Immunol. 2008;181:6923-6933.

Yauch LE, et al. A protective role for dengue virus-specific CD8+ T cells. J Immunol. 2009; 182:4865-4873.

Yauch LE, et al. CD4+ T cells are not required for the induction of dengue virus-specific $\mathrm{CD} 8+\mathrm{T}$ cell or antibody responses but contribute to protection after vaccination. J Immunol. 2010;185:5405-5416.

Young PR, et al. An antigen capture enzyme-linked immunosorbent assay reveals high levels of the dengue virus protein NS1 in the sera of infected patients. J Clin Microbiol. 2000;38:1053-1057.

Zuniga $\mathrm{R}$, et al. Relative dominance of Gag p24-specific cytotoxic $\mathrm{T}$ lymphocytes is associated with human immunodeficiency virus control. J Virol. 2006;80:3122-3125. 